\title{
Cross-strait Economic Interdependence and the Prospects for Peace between Mainland China and Taiwan
}

\author{
By Li ZHANG
}

A Thesis Submitted to

Victoria University of Wellington In Fulfillment of the Requirements for the Degree of Master of Arts

In International Relations

School of History, Philosophy, Political Science \& International Relations

Victoria University of Wellington

2012 


\section{Abstract}

The further development of economic globalisation causes the status and effect of economic factors to continuously increase in international relations. This new characteristic is increasingly apparent in cross-strait relations as the course of the reform and opening-up in mainland China, as well as the development of cross-strait economy and trade. Particularly since the mainland and Taiwan signed Economic Cooperation Framework Agreement (ECFA) in 2010, economic development has become one of the most important issues between the two sides.

Since the détente between the mainland and Taiwan in the 1980s, cross-strait economics and trade have displayed two primary characteristics. First, the volume of trade, the amount of investment, and especially the economic interdependency between the two sides are all constantly increasing. Second, although under the influence of fluctuating political relations, the cross-strait economic relationship is still maintaining a stable development tendency. Due to the impact of economic globalisation, both the mainland and Taiwan are re-examining their own economic interests and have realized that economic relations form the cornerstone of their relationship. The expanding common interest which is generated from the deepening cross-strait economic exchanges between the mainland and Taiwan is becoming the key factor in both governments' political considerations. Cross-strait economic and trade development is thus becoming an interests mechanism which maintains the framework of peace and stability across the Taiwan Strait.

This thesis argues that cross-strait economic interdependence and cross-strait relations are inherently and interactively related. From the viewpoint of Neoliberalist Theory and Interdependent Theory, and on the basis of the development course of cross-strait economy and trade, this article analyzes the interactive effect between the cross-strait economy and cross-strait relations, especially the political relations from many factors such as the signing of ECFA, the impact of Taiwanese businessmen's investment in the mainland, and the mainland's Taiwan policy. This thesis concludes that on the one hand, the increase in cross-strait economic interdependence will 
promote peace and stability across the Taiwan Strait. On the other hand, stable cross-strait relations will also provide a policy guarantee and a peaceful scope for the future development of the relationship between mainland China and Taiwan. 


\section{Table of Contents}

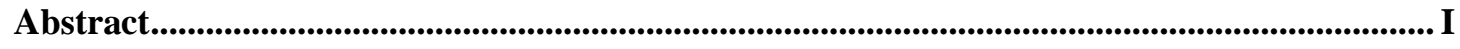

List of Figures and Table ...............................................................................................

List of Abbreviations...................................................................................................................... VI

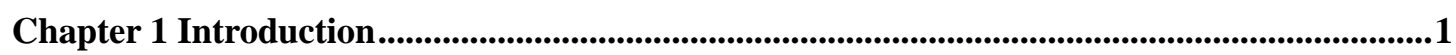

Chapter 2 Cross-strait History Review from 1949 to Today ......................................................4

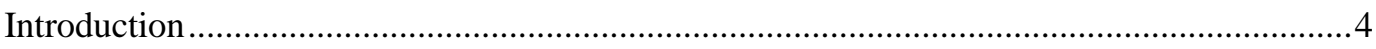

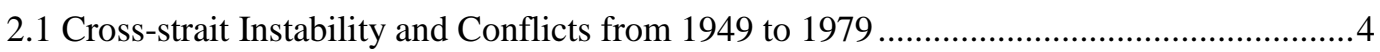

2.2 The Emergence of Cross-strait Political Contact and Continuing Growth of Cross-Strait

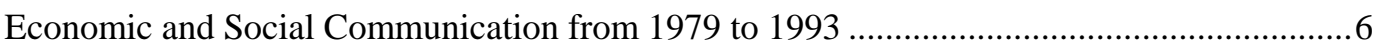

2.3 Ongoing Cross-Strait Political Tensions from 1994 to 2007 and Deepening Economic

Interdependence between the Mainland and Taiwan.................................................................

2.4 The Ease of Cross-strait Political Tensions and Continuing Economic Integration between the Mainland and Taiwan since the KMT President Ma Ying-jeou Came to Power in May 2008

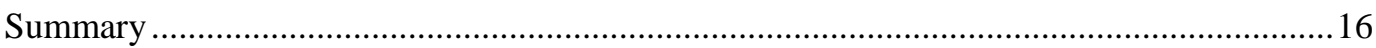

Chapter 3 Literature Review: Realism, Liberalism and Interdependent Theory with

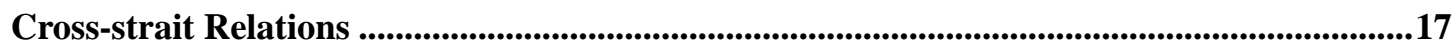

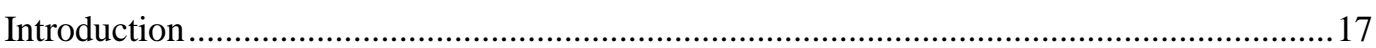

3.1 Classical \& Structural Realism with Cross-strait Relations ................................................17

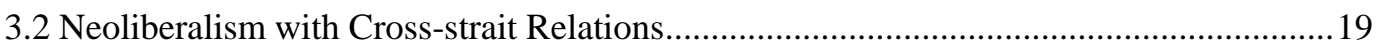

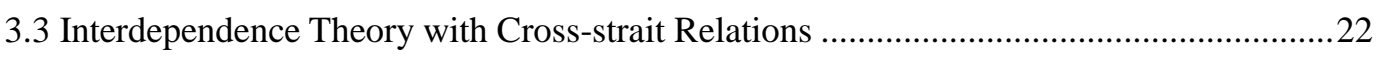

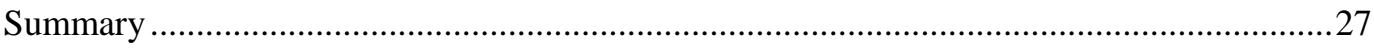

Chapter 4 Assessing Cross-strait Relations through ECFA .....................................................28

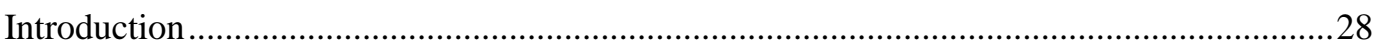

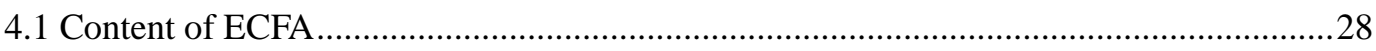

4.1.1 Opening Markets for Trade in Goods and Services.............................................29

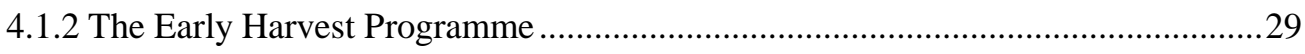

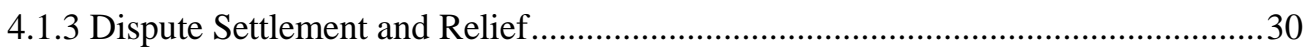

4.2 A Comparison of Sino-US Relations under the APEC Mechanism with Cross-strait

Relations under ECFA Mechanism — Similar Economic Motivations .......................................31

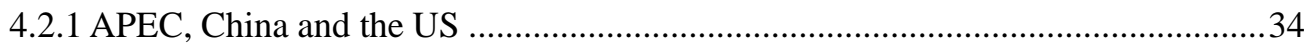

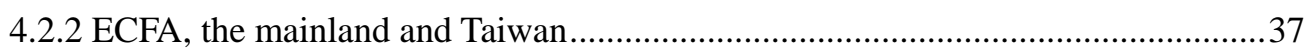

4.3 ECFA will Promote Peace and Stability between the Mainland and Taiwan .....................43

4.3.1 ECFA Promotes Cross-Strait Peace and Stability by Strengthening Mutual

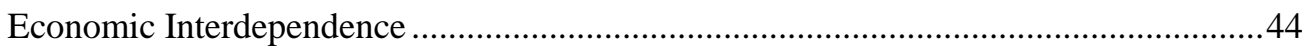

4.3.2 ECFA Provides a Platform and Institutional Experience for Future Cross-strait

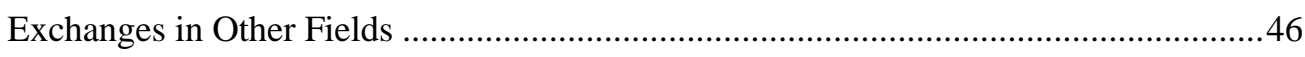

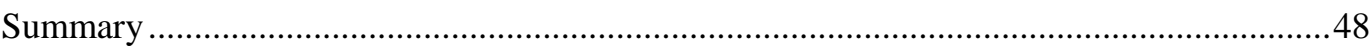

Chapter 5 Role of Taiwanese Business People: An Important Element for Cross-strait Peace

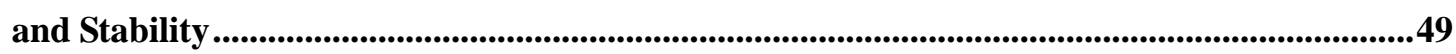

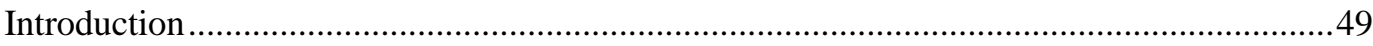

5.1 History and Current State of Investment by Taiwanese Business People on the Mainland 


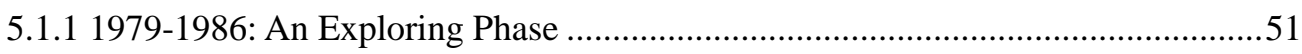

5.1.2 1987-1993: A Fast Growing Phase..................................................................... 51

5.1.3 1994-2000: A Slowdown Phase......................................................................52

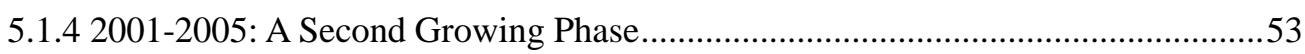

5.1.5 2005-Present: A Fully Developing Phase ............................................................54

5.2 The Influence of Taiwanese Business People on the Economies of Both Taiwan and the

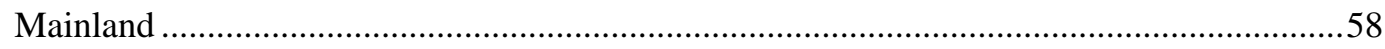

5.2.1 Promoting Economic Development across the Taiwan Strait ..............................59

5.2.2 Promoting Institutional Development of Cross-strait Economic and Trade

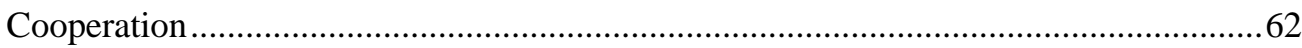

5.3 The Role of Taiwanese Business People in Cross-Strait Social and Cultural Exchanges and Blending .

5.4 The Close Relations among Taiwanese Business People with Both Governments across

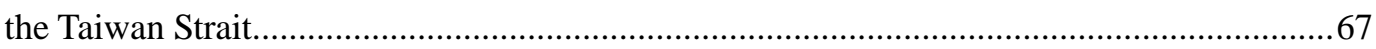

5.4.1 Taiwanese Business People and the Mainland Government ...............................69

5.4.2 Taiwanese Business People and Taiwan's Political Parties .................................. 74

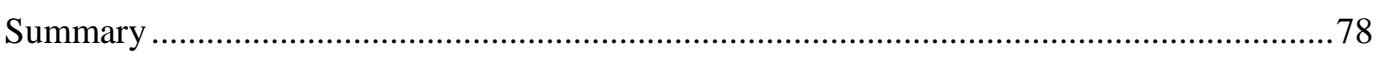

Chapter 6 Mainland China's New Policy towards Taiwan ..........................................................80

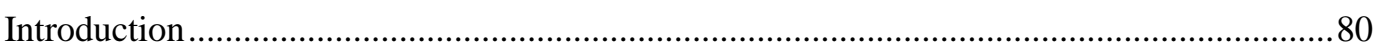

6.1 The Core of Hu Jintao's Speech: Mainland's Implementing "Peaceful Development"

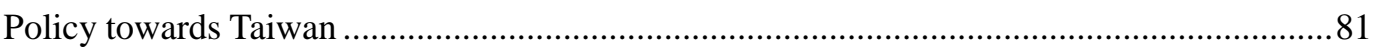

6.2 Interpreting Mainland's "Peaceful Development" Policy towards Taiwan.......................82

6.2.1 The Target of the Mainland's "Peaceful Development" Policy towards Taiwan:

Realizing Cross-Strait Peaceful Reunification ........................................................ 82

6.2.2 The Political Basis for the Peaceful Development of Cross-Strait Relations: the One China Principle

6.2.3 A Method of Peaceful Development across the Taiwan Strait: Deepening Cross-strait Social and Economic Exchanges and Cooperation

6.2.4 The Impetus of Peaceful Cross-Strait Development: Relying on the Taiwanese

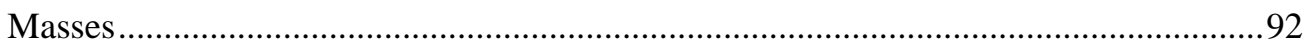

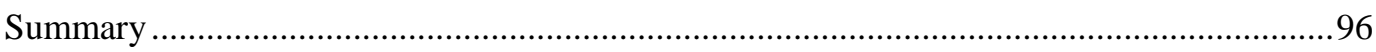

Chapter 7 Conclusion ............................................................................................................................98

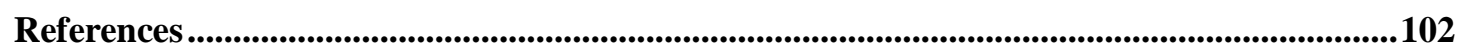




\section{List of Figures and Table}

Figure 1 China's Imports \& Exports to and from the US from 1990 to 1999 ...........................33

Figure 2 China's Imports \& Exports to and from the US from 1984 to 2000 (by Customs) ..33

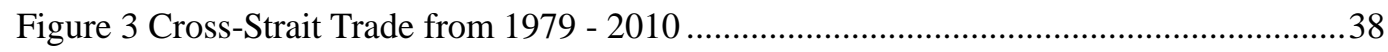

Figure 4 Cross-Strait Trade Interdependency from 1992 to 2005 .............................................39

Figure 5 Taiwan Business People's Mainland Investment from 1989 to 2010 ........................50

Figure 6 Ranking of Taiwan's Investment on Total Mainland's Overseas Investment from

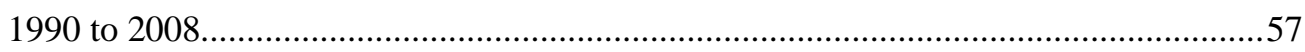

Figure 7 Main Areas of Taiwan Business People's Mainland Investment from 1991 to July 2009 . .58

Figure 8 Main Industries of Taiwan Business People's Mainland Investment from 1991 to July 2009 .60

Figure 9 Cross-strait Personal Exchange from 1987 to 2010 .................................................66

Figure 10 Cross-strait Communication from 1987 to 2010 .................................................66

Table 1 Taiwan's Total Overseas Direct Investment \& Taiwan's Mainland Investment from 1981 to 2003 


\section{List of Abbreviations}

APEC - Asia-Pacific Economic Cooperation

ARATS - Association for Relations across the Taiwan Strait

ASEAN - Association of Southeast Asian Nations

$\mathrm{CCP}$ - Chinese Communist Party

DPP - Democratic Progress Party

ECFA - Economic Cooperation Framework Agreement

FTA - Free Trade Agreement

GDP - Gross Domestic Product

GNP - Gross National Product

KMT - Guomindang or Kuomintang

MAC - Mainland Affairs Council

NUC - National Unification Council

PLA - People's Liberation Army

PRC - People's Republic of China

RMB - Renminbi (Chinese Currency, unit: yuan)

ROC - Republic of China

SCNPC - Standing Committee of the National People's Congress

SEF - Strait Exchange Foundation

US - United States of America

WTO - World Trade Organization 


\section{Chapter 1 Introduction}

The Taiwan Strait used to be a "dire strait" because it had caused direct military confrontations between the People's Republic of China (the PRC) and the United States of America ("US") during and after the Cold War. The situation across the Taiwan Strait is still important in international relations today because it remains a major flashpoint in East Asia, as one of the few unresolved problems of the Chinese Civil War/Cold War conflicts. It is widely agreed that the Taiwan issue originally stemmed from the Chinese Civil War. In the past sixty years, cross-strait relations have undergone a range of situations ranging from pure military confrontation to economic and social cooperation and interdependence, especially since the PRC changed its policy from liberating Taiwan by force to unifying Taiwan with the Chinese mainland by peaceful means. Cross-strait social and economic integration have become the predominant theme since 1979. However, in recent years, the relationship between the two sides has nevertheless experienced ups and downs, particularly for reasons attributable to the Taiwan independence issue.

Changes began to take place after Ma Ying-jeou took office as the President of Taiwan in May 2008. Economic and social ties between the two sides have reached their closest point in decades since President Ma assumed office (Ide, 2010). Cross-strait relations have also witnessed important progress and marked a historic turning point, such as the achievement of the three direct links (direct air, sea and postal services) across the Taiwan Strait, the opening of tourism offices in Beijing and Taipei in May 2010, and the signing of the cross-strait Economic Cooperation Framework Agreement (ECFA) one month thereafter. Furthermore, mainland tourists are now allowed to travel to the island of Taiwan for the first time since 1949. Even though cross-strait political tensions still exist, economic interdependence between mainland China and Taiwan is developing so fast that mainland China replaced the United States to become Taiwan's largest trading partner in 2003 (Lin \& Yi, 2006). In contrast Taiwan, with an estimated one million business people and their families 
living in the mainland (Hsiung, 2009, p.130), remains one of the most important investors and trading partners of the mainland. However, since Ma was elected as the president, the recent upsurge in the Taiwanese public attitude towards the mainland has led some in Taiwan to criticize President Ma's efforts to foster economic rapprochement with the mainland, viewing the economic interdependence with the mainland as risking Taiwan's sovereignty (EIU ViewsWire, 2010). Some even revile the signing of ECFA as "a first step toward eventual unification" (Tsai, 2010, p.4).

The question of whether and how economic interdependence affects states' political relations is not a new topic in international relations: this theme has been widely studied by numerous scholars, such as Robert O. Keohane, Arthur R. Stein and Albert O. Hirschman. Generally speaking, liberalism expounds the positivist argument that "an open international political economy, with rules and institutions based on state sovereignty, provides incentives for international cooperation and may even affect the international constitutions of states in ways that promote peace" (Koehane, 1990, p.166-167). In contrast realist scholars hold completely different views and argue that interdependence either increases the likelihood of war or is not related to its initiation. On the one hand, economic interdependence heightens the likelihood of war by increasing the numbers of opportunities for conflict, such as the trade inequality and asymmetry between states (Hirschman, 1980; Stein, 1993). On the other hand, interdependence is unrelated to war and other forms of military conflict, which is driven primarily by political and strategic concerns (Waltz, 1993; Holsti, 1986).

History has played a pivotal role in the relationship between mainland China and Taiwan. This study begins with a brief review of the two sides' history in the last six decades. Reviewing this history will enable readers to gain a better understanding of how the Taiwan issue arose, why it developed from pure military confrontation to the current social and economic interdependence and why this will lead to peace and stability across the Taiwan Strait. A brief review of cross-strait history in the past six decades will be the main focus of Chapter Two.

Chapter Three will provide an overview of the existing literature, especially the 
recent debates on the correlations between cross-strait economic interdependence and the political relationship between mainland China and Taiwan. In this chapter, the main arguments between realism and liberalism, including economic liberalism and institutionalist liberalism will become the objects of more detailed scrutiny.

Chapter Four will focus on ECFA to explore cross-strait political relations, firstly introducing the detailed contents of ECFA. Secondly, a comparison of the economic motivations for China and the US to join the Asia-Pacific Economic Cooperation (APEC) follows as this comparative research provides inspirational thinking on interpreting the trend of cross-strait economic relations under the mechanism of ECFA. Finally, this chapter applies Neoliberalism Theory and Economic Interdependence Theory to explore the significance of ECFA to peace and stability across the Taiwan Strait .

The next case study which is the political role of the Taiwanese business community in the process of cross-strait economic interdependence will be the main focus of Chapter Five, in which, I will cite the newest data which indicates the extent and the depth of the cross-strait economic and social integration which was mainly fueled by the Taiwanese business community's vast investment in the mainland. Furthermore, I will examine the Taiwanese business community's role in signing ECFA and other cross-strait agreements in the past two to three decades. Also, the Taiwanese people's close and private relations with both Chinese government officials and the Taiwanese political parties will be explored.

Chapter Six mainly focuses on mainland China's new policy towards Taiwan the peaceful development policy. In this chapter, it firstly analyzes the CCP President Hu Jintao's speech at the conversazione held in commemoration of the $30^{\text {th }}$ anniversary of the issue of the Message to Taiwan Compatriots at the end of 2008. Secondly, it explores the targets, political basis and method the mainland is adopting and the impetus for realizing cross-strait peaceful development respectively by expounding the mainland's peaceful development policy towards Taiwan.

Chapter Seven forms the overall conclusion of this thesis. It summarizes the key findings in the previous chapters and also answers the main argument. 


\section{Chapter 2 Cross-strait History Review from 1949 to Today}

\section{Introduction}

In the past six decades, the relationship between mainland China and Taiwan has undergone a dramatic change from being complete enemies to close economic partners to one another from the period of from 1949 to the present. In this chapter, a brief historical review of the relationship between mainland China and Taiwan in the past six decades will be studied in detail. According to the social, political and economic changes occurring between the mainland and Taiwan, cross-strait relations are divided into four periods as follows. From 1949 to 1979, there was constant instability, conflicts and even military buildup between the mainland and Taiwan. From 1979 to 1993 cross-strait political contact and continuing economic growth has appeared. From 1994 until 2007, cross-strait relations entered into a state of being further economically interdependent while political tensions constantly occurred. The last period is from 2008 to the present in which both cross-strait economic and political relations started to warm up after the KMT President Ma Ying-jeou assumed the presidency.

\subsection{Cross-strait Instability and Conflicts from 1949 to 1979}

The Taiwan issue originally stems from the Chinese Civil War. In 1949, after being defeated by the Chinese communists led by Mao Zedong, Chiang Kai-shek's government fled mainland China for the island of Taiwan. On the $1^{\text {st }}$ of October, 1949, the PRC was founded in Beijing by Mao Zedong's Communist Party. In that same year, the Republic of China (the ROC) which was governed by Chiang Kai-shek's Nationalist party, also known as the Kuomintang ("KMT") in Cantonese or the Guomindang in Mandarin began to settle on the island of Taiwan and started to gradually develop this island economically, politically, and militarily (Smith, 2007).

In the mainland, after the establishment of the PRC, the Chinese leaders and 
Chinese people regarded Taiwan as their own national territory. To the Chinese people and government, the Taiwan issue is extremely important because it involves China's territorial integrity. Due to the long history of humiliation during which China was treated unequally by foreign forces, the Chinese people exhibit strong emotions in matters concerning national independence, territorial integrity and national sovereignty. The PRC used the rhetoric of liberating Taiwan as the main guiding strategy to deal with Chiang Kai-shek's KMT government during the period from 1949 to 1979. A Xinhua News Editorial of March 15, 1949, titled "Zhongguo renmin yiding yao jiefang Taiwan" ["The Chinese people certainly will liberate Taiwan"] became the first official slogan to deal with the Taiwan issue (Wachman, 2007). The PRC leadership believed the only way to free Taiwan and to achieve a final reunification between Taiwan and the mainland was to fight with the United States and its ally - the ROC regime headed by Chiang Kai-shek and his KMT. Furthermore, the PRC dispatched massive military troops and equipment to Fujian Province, which is the closest province on the mainland to the island of Taiwan, and started shelling off Jinmen, Taiwan's closest islands to the mainland, every other day. Therefore, in the three decades after the PRC was established, the situation across the Taiwan Strait was fraught with hostility, military confrontation and military build-up. An example of the extensive military confrontation across the Taiwan Strait is when the US dispatched its Seventh Fleet to safeguard Taiwan which was facing a potential PRC military invasion at the beginning of the outbreak of the Korean War in the early 1950s (Zhang, 2004).

The ensuing massive military buildup in both the mainland and Taiwan has caused separation, polarisation, military confrontation and instability across the Taiwan Strait for the three decades since 1949. The use of force also remained the PRC's dominant strategy to reunify China. There were no social or economic contacts across the Taiwan Strait in the three decades after the PRC was established in 1949. 


\subsection{The Emergence of Cross-strait Political Contact and Continuing Growth of Cross-Strait Economic and Social Communication from 1979 to 1993}

The late 1970s marked a historical turning point in the PRC's history because the year 1978 brought the inception of mainland China's economic and political reforms. Changes across the Taiwan Strait also began to take place after the PRC leader Deng Xiaoping came to power in 1978. The mainland started sending new signals to its Taiwanese compatriots and shifted its attitude towards Taiwan away from "liberation by force" and towards "peaceful unification". On January $1^{\text {st }}, 1979$, the PRC announced the end to every-other-day shelling of Jinmen and forwarded the famous Message to Taiwan Compatriots. This was the first time since 1949 that the PRC had sought to bring the cross-strait military confrontation to an end and expressed a wish for three links and expanded communications across the Taiwan Strait (Wu, 1995, p.20). Furthermore, in the early 1980s, the PRC leader Deng Xiaoping formulated the "one country, two systems" policy as the guideline for reunifying China peacefully. This policy suggested that there would only be one China in the world, but independent Chinese regions such as Taiwan, Hong Kong and Macau, could still maintain their capitalist economic, judicial, financial and political systems, while the rest of China upheld the socialist system. In the Taiwan case, the PRC suggested that after the reunification of China, Taiwan would remain as highly autonomous and democratic as before (Song, Wang \& Sun, 2011).

In Taiwan, the late 1970s also marked a historical turning point. Economically, Taiwan has transformed from cheap, labor-intensive manufacturing industry into more export-oriented competitive industry, such as infrastructure, advanced electronics and heavy industry. Taiwan's export-oriented economy grew so fast that in the late 1970s it had become one of the Four Asian Tigers along with South Korea, Hong Kong and Singapore. Politically, the KMT still remained the only legitimate ruling party in Taiwan and martial law was still enforced in Taiwanese society (Roy, 2003). Diplomatically, in December 1978 the US formally transferred its diplomatic relations and recognition from the ROC government in Taiwan to the PRC (Wachman, 2007). From then on, Taiwan started to suffer a period of isolation by major powers and 
international organizations. In response to the shift of the PRC's Taiwan policy from military liberation to peaceful reunification, Chiang Ching-kuo's KMT government in Taiwan responded negatively and outlined what came to be known as the "Three Nos" policy - no contact, no compromise, and no negotiations with the mainland (Johnston \& Ross, 1999).

However, Taiwan Society in the 1980s had undergone a dramatic change. Politically, the society of Taiwan became more and more democratic especially after the termination of martial law in 1987 (Johnston \& Ross, 1999, p.61). Economically, people in Taiwan were becoming increasingly wealthier. In 1986, there were a group of senior mainland veterans which were brought to Taiwan by the KMT after Chiang Kai-shek lost mainland China to the Chinese Communist Party (the CCP), began to ask for permission to visit their family in the mainland after four decades of separation across the Taiwan Strait. The mainland veterans' campaign gained massive support from Taiwan public, including some open-minded KMT members and some DPP legislators. Under such heavy pressure from society, the KMT had little choice but to lift its ban and allow Taiwanese people to visit the mainland (Hsiao \& So, 1996).

From the moment Taiwanese were allowed to visit the mainland, a large number of people from Taiwan visited mainland China for tourism and other civil purposes. Statistics show that from 1988 to 1993 , people from Taiwan made more than five million visits to the mainland (Mainland Affairs Council, 2003). Due to the affinities of language, culture and the geographic closeness, massive Taiwanese investments to the Chinese eastern coastline followed after their visits to the mainland. In 1990 Taiwan had already become the number two investor in Mainland China, surpassing even the United States and Japan (Hsiao \& So, 1996, p.3). Cross-strait trade also grew dramatically from 1979 to 1993 . In particular, in the year 1984, 1985 and 1993, cross-strait economic trade in total increased by $123 \%, 99.1 \%$ and $94.3 \%$ respectively. Statistic shows, the mainland's usage of Taiwanese investment in reality increased more than $100 \%$ in the period from 1991 to 1993 (Lin \& Yi, 2006, p.10).

The massive civil-society contacts across Taiwan strongly undermined the KMT's 
"Three Nos" policy. Institutionally, in the beginning of the 1990s, the Taiwan government established different organisations in order to better deal with the increasing cross-strait social and economic exchanges. On 21 September 1990, President Lee Teng-hui established the National Unification Council (the NUC) to draft and amend a new China policy (Chao \& Myers, 2000, p.21). On 28 January 1991, the NUC devised a three-phase process embodied in the National Unification guidelines calling for China's reunification. In the first phase, the two sides across the Taiwan Strait should denounce the use of force in dealing with cross-strait affairs, enlarge cross-strait nonofficial, social exchanges, and respect each other's jurisdiction within their territories. In the second phase, official communication should be established following the mutual understanding and trust built through massive social contact across the Taiwan Strait. At this stage, the three direct links (direct air, sea links and direct postal service) could be allowed and high-ranking officials from both sides could then visit each other. In the third and final phase, the two sides across the Taiwan Strait could set up different institutions to discuss and facilitate the eventual reunification of a democratic, free, and prosperous China (Chao \& Myers, 2000). Furthermore, in February 1991, the Strait Exchange Foundation (SEF) was established in Taipei to deal with the increasing cross-strait social and economic affairs (Yahuda, 1993). Beijing soon established a counterpart organization to the SEF which is the Association for Relations Across the Taiwan Straits (ARATS) in December 1991 (Johnston \& Ross, 1999). Beginning in November 1991, representatives of these two institutions met and discussed some historical and economic issues. An oral agreement which was known as the "1992 consensus" came to fruition in November 1992 in the meeting between the SEF and ARATS held in Hong Kong. In the "1992 consensus", both the mainland and Taiwan representatives agreed to adhere to the "One China Principle" and committed itself to work toward unification even though the two sides had their own interpretation thereof (Ling, 2002).

To sum up, in the period from 1979 to 1993, the PRC's policy towards Taiwan became much less confrontational than it had been during the 1950s and 1960s. 
Peaceful unification and the "one country, two systems" policy took up the dominant elements in the PRC's strategy towards Taiwan. Cross-strait economic relations started and strengthened from the early 1980s following Taiwan's robust investment in the mainland. Since the early 1990s, more than half of Taiwanese outside investment is to mainland China (Chung, 2008). Also around this time, social and economic relations across the Taiwan Strait started to grow dramatically. In order to deal with the daily increasing cross-strait social and economic exchanges, the SEF and ARATS were established in Taipei and Beijing respectively. These two institutions were staffed by government officials and their formal meetings and negotiations also marked the emergence of cross-strait political contact.

\subsection{Ongoing Cross-Strait Political Tensions from 1994 to 2007 and Deepening}

\section{Economic Interdependence between the Mainland and Taiwan}

The year 1994 began with signs of a possible thaw in cross-strait political relations when Lee Teng-hui's support of Taiwan's separation from China came to light. In an interview with a Japanese writer, Ryotaro Shiba, Lee openly expressed his "grief at being Taiwanese" and compared himself to Moses leading the children of Israel out of bondage. He also described the KMT as an "alien" regime (Hickey, 1999). Furthermore, in April 1995, Lee demanded that Beijing should accept the reality of two separate Chinese governments in his own "Six Principles" (Roy, 2003). Lee’s provocative remarks outraged the mainland, which started to denounce Lee as a separatist and charged him with orchestrating a Taiwan independence movement. For the mainland, Lee's visit to the US and his speech as Head of State at Cornell University was the final straw. Beijing considered Lee to be taking advantage of the mainland's conciliatory posture and trying to promote Taiwan independence. Therefore, from July 1995 to March 1996, the People's Liberation Army (the PLA) began test-firing missiles into the waters off Taiwan's coast. The PLA also engaged in naval exercises and its largest amphibious exercises in the Taiwan Strait. The mainland's military exercises were considered a coercive response to Lee's betrayal of the one China principle. However, the US decision to dispatch its aircraft carrier, the 
Nimitz to pass through the Taiwan Strait and the Clinton administration's announcement to further deploy another aircraft carrier Independence together with the supporting ships to international waters near Taiwan, brought the third Taiwan Strait crisis to its non-confrontational climax (Roy, 2003).

In 1996 Taiwan's first presidential election was underway, and many felt that one aspect of the mainland's military exercises so close to the Taiwan Strait was to affect the Taiwanese people's voting behaviour. As Lee's political opponent Chen Li-an asserted, "If you vote for Lee Teng-hui, you are choosing war", nevertheless the first presidential election still achieved great success when Lee Teng-hui became Taiwan's first popularly-elected president (Roy, 2003, p.199). However, during Lee's second term of presidency, he was not less provocative towards the mainland than he was in his first. In an interview with Deutsche Welle [German Wave], Lee Teng-hui described cross-strait relations as a "state to state relationship" or "at least a special state to state relationship"; this was known as "two states theory" (Lee, 1999, p.26-33). Again, Beijing was infuriated by Lee's anti-reunification actions and suspended dialogues between the SEF and ARATS (Zagoria \& Fugarino, 2003, p.115). This time, the attack from Beijing was mainly verbal, rather than in the form of military exercises. For example, immediately after Lee Teng-hui's "two states" remarks, the mainland's major media reports and academic articles all denounced and criticized Lee as a "betrayer" and a "separatist" of the Chinese motherland, the definite failure of his conspiracy, and Lee himself would be punished by Chinese history (China News, 2000; Hai, 1999).

Lee Teng-hui's political career ended in 2000 when his successor Chen Shui-bian, a Democratic Progress Party (the DPP) leader, was elected president of Taiwan. However, the DPP is the dominant party in the pan-green camp and it has been traditionally associated with a strong advocacy of a Taiwanese identity and Taiwanese independence. Chen was also widely considered a resolute supporter of pro-Taiwan independence movement. In 2002 Chen not only devised the "Two Countries - Taiwan and the Mainland - One On Each Side Theory", but also demanded legislation to enable a "referendum" on Taiwan's future (Huang, Zhuang, Huang, Liu, Yu \& Liu, 
2002). As mentioned above, the Taiwan issue is of significant import to the mainland as it involves China's national sovereignty and territorial integrity. Therefore, the mainland government's attitude towards Taiwan is considered determined and entrenched. In response to Chen's anti-reunification remarks and the DPP's pro-independence actions, in 2005 the PRC enacted an anti-secession law asserting that it would unquestionably resort to "non-peaceful means" if Taiwan were to declare formal independence (People's Daily, 2005). The legalization of the mainland's "use of force" to achieve unification did not stop Chen's provocative actions towards the PRC. In 2007, Chen declared "four demands and one without", which indicated "Taiwan demands independence, Taiwan demands to change its official name from the ROC to Taiwan, Taiwan demands a new constitution, Taiwan demands development and there is no middle way, only a question of reunification with the mainland or Taiwan independence" (Zhang, 2007). Like Lee Teng-hui, Chen Shui-ban's anti-unification remarks and his support for the promotion of Taiwan independence caused ongoing cross-strait political tensions during his presidency from 2000 to early 2008.

Unlike the constant political tensions between the mainland and Taiwan, cross-strait economic and social integration dramatically deepened during the period from 1994 to early 2008. According to the 2002 Mainland Affairs Council (MAC) statistics, cross-strait trade was around $\$ 40$ billion (Fu, 2008, p.143). Two years later in 2004, cross-strait trade quickly doubled, reaching \$78.3 billion (Lin \& Yi, 2006, p.5). Again in 2007, bilateral trade between the mainland and Taiwan reached $\$ 124.5$ billion (Zhu, 2008, p.34). Taiwan's robust investment in the mainland is another example of fast growing cross-strait economic integration. From the year 1990 to 2004, the average increase rate of Taiwan's investment to mainland China was $29.1 \%$ (Lin \& Yi, 2006). According to the Ministry of Commerce of the PRC, as of 2006, mainland China had approved 71,847 Taiwanese investment projects on the mainland in total and the contracts they signed involved $\$ 101$ billion from the Taiwan side. Taiwanese investment in the mainland in 2006 also accounted for $70 \%$ of Taiwan's total foreign investment programmes approved by the government that year. Due to 
the ever-increasing economic ties, Taiwan's economic dependence on the mainland also grew year by year. In 2001, Taiwan's export dependence on the mainland was $17 \%$, while in 2006 , it immediately grew to $40 \%$ (Cao, 2008). In terms of the social communications between the two sides, by the end of 2007, the number of Taiwanese people visiting the mainland was larger than 47 million. To take 2007 for example, due to the daily increasing social and economic integration across the Taiwan Strait, more than 4.6 million Taiwanese people - this is one sixth of Taiwan's total population - visited the mainland for tourism, education, health, physical culture, media and economic activities (Zhang, 2009).

In sum, cross-strait political relations deteriorated dramatically between 1994 and 2007 due to Taiwanese leaders, such as the anti-unification and pro-Taiwan independence actions of Lee Teng-hui and Chen Shui-bian. As a consequence, there were ongoing cross-strait political tensions between the two sides in the period from 1994 to 2007. However, at the same time, cross-strait economic and social integration further deepened dramatically notwithstanding their ongoing political tensions.

\subsection{The Ease of Cross-strait Political Tensions and Continuing Economic Integration between the Mainland and Taiwan since the KMT President Ma Ying-jeou Came to Power in May 2008}

The year 2008 began with a positive sign in cross-strait relations when the KMT candidate Ma Ying-jeou was elected president of Taiwan. Being different from the DPP, the KMT is the dominant party in the pan-blue camp and it supports eventual unification with the mainland. In order to ease cross-strait political tensions and repair their relationship, the KMT government showed a positive posture towards further economic and social integration with the mainland. Therefore, one month after Ma assumed the presidency, semi-official dialogues between the SEF and ARATS were resumed after the previous nine years' suspension (Zagoria \& Fugarino, 2003, p.115). Some milestone progress were attained, such as the achievement of three direct links, the lifted ban of mainland tourism travel to Taiwan,, and the signing of the cross-strait 
Economic Cooperation Framework Agreement (ECFA). The following few paragraphs will talk about these recent cross-strait achievements in detail.

In the past, if Taiwanese travellers planed to visit mainland China, they had to transfer to a separate flight at an intermediate location, usually Hong Kong or Macau, before flying on to mainland cities. This unnecessary transfer not only wasted travelers' time, but also squandered extra money on fuel, especially when the destination cities lay in northern China. For example, a glance at a map shows that the mainland China city of Beijing lies to the northwest of Taipei; however passengers from Taipei first had to fly southwestward to Hong Kong before travelling northward to their final destination. This detour extended the trip to at least 1.4 times over the shortest route between the two cities (Chung, 2008). On June 13, 2008, Chiang Pin-kung, Chairman of the SEF, and his mainland counterpart Chen Yunlin, Chairman of the ARATS, met in Beijing and signed agreements to allow direct charter passenger flights across the Taiwan Strait on a regular basis (Chung, 2008), which was to say every weekend from Friday to Monday. However, due to the rapid economic growth and integration across the Taiwan Strait, daily direct flights have become the pressing demand of people from both sides. Following the meetings between the SEF and ARATS in November 2008, daily direct cross-strait charter flight service began one month after the two sides' dialogues (State Department Documents, 2010).

As the result of four rounds of negotiations between the SEF and ARATS, in December 2008, the mainland and Taiwan finally ended the fifty-nine year long ban on direct air and sea transport and postal services. The goal of "three direct links" across the Taiwan Strait was finally achieved. Nowadays, a total of 270 regular flights service 31 mainland cities every week (Chung, 2010), not only greatly saving passengers' time and costs, but also shortening the distance across the Taiwan Strait. SEF Chairman Chiang Pin-kung described the three direct links as being like "highways" (Wang, 2010, p.147) connecting Taiwan and the mainland. Travelling between the mainland and Taiwan is now so convenient that, the dream Jianwei Wang has described as "having breakfast in Taiwan, lunch in Shanghai, dinner in Xiamen, and returning to Taiwan for a midnight snack" is becoming reality (Wang, 2010, 
p.147-48).

The convenience of cross-strait flights has not only shortened the distance between Taiwan and the mainland, but also promoted the tourist industry in Taiwan. As one of the agreements between the SEF and ARATS, Taiwan has opened its tourist market to mainland travellers since July 2008 (Gu, 2010). Today mainland tourists' flock to the island in robust numbers and a wide range of economic ties are budding between the two sides (Carpenter, 2010). According to Taiwan government statistics, mainland tourists' arrivals in Taiwan have swelled to up to 3,400 per day (Jonathan, 2010), comparing this with the number of mainland tourists in 2008, which was just 55,000 in total, which indicates the rate of increase in that period. The mainland, with 1.3billion people, has the largest population of any nation in the world and its people wax richer daily as a result as the three decades of economic reforms. Cross-strait survey statistics show that more than $70 \%$ of mainlanders wish to visit Taiwan $(\mathrm{Gu}$, 2010). Due to mainland China's large population, the mainland's potential contribution to Taiwan's tourism industry is promising. Not surprisingly, some scholars have predicted that the mainland is likely to become Taiwan's top destination for visitors and travellers after Taiwan's tourism market opened to mainland visitors (Wang, Sun \& Zheng, 2010). In order to meet the growing needs of the tourism industry, the mainland and Taiwan opened tourism offices in Beijing and Taipei respectively in May, 2010. This event marked the first official presence on both sides of the Taiwan Straits since the two went their separate ways during the 1949 Civil War (Ide, 2010). Although the functions of the tourism offices are to promote travel and cultural exchanges, the offices in Beijing and Taipei are staffed mainly by government officials. Thus the opening of tourism offices by the two sides is seen as a very positive development and symbolic of mutual efforts to strive towards peace and compromise.

In order to meet the highly rapid economic integration across the Taiwan Strait, on June $29^{\text {th }}, 2010$, ECFA was signed between the mainland and Taiwan in Chongqing (The Economist, 2010). According to President Ma, for Taiwan to sign ECFA with the mainland to relax cross-strait trade regulations and reduce tariffs, and complete an 
industry upgrade to build an innovation-based economy, a "Golden Decade" of sustained development would become an attainable goal for Taiwan (BBC, 2010). According to the Taiwanese government, ECFA will prevent Taiwan's economic marginalisation. Currently, Taiwan is recognized by only twenty-three nation states. The states which recognise Taiwan are considered peripheral and usually highly dependent on Taiwanese foreign aid (Fu, 2008). Without formal diplomatic relationships with the major economic countries, Taiwan has been excluded from a recent spate of free-trade agreements (FTAs). A closer examination of ECFA and its impacts on both cross-strait economic and political relations will be studied together with the theory of institutional liberalism in Chapter Two of this research paper.

Like the rapid economic improvements between the mainland and Taiwan, their political relationship has also turned a historical corner point since Ma Ying-jeou assumed office. Take the KMT Honorary Chairman Lien Chan and the General Secretary of the CCP Hu Jintao for example: in order to re-initiate the two sides' economic negotiations, Lien Chan made three trips to the mainland, in 2008, 2009, and 2010, respectively. He met with $\mathrm{Hu}$ Jintao each time. Some constructive principles and guidelines in terms of closer cross-strait economic and political ties were further established. Other political leaders from both sides have also made a show of mutual trust towards one other. PRC Premier Wen Jiabao uttered his cherished wish to visit the island of Taiwan one day and asserted that 5,000 years of shared culture and history may not be swept away by mere "political developments" over the past 60 years. "Squabbles between brothers do not sever blood bonds. I know we will reconcile our differences," Wen told a press conference at the end of China's annual parliamentary session (Edmonton Journal, 2010). Referring to the close economic and social ties subsisting between the mainland and Taiwan, President Ma also said "We should cherish the fact that the two sides [the KMT and the CCP], which have fought each other for decades, are finally able to work on building mutual trust" (BBC, 2010). Furthermore, on $9^{\text {th }}$ May, 2009, Ma Ying-jeou granted an interview to a Singaporean morning paper, in which he clearly announced that, if he could win the Taiwan presidential election in 2012, there would be a "pressing need 
for negotiations", he "would not rule out political talks and negotiations between the mainland and Taiwan" (Taihainet, 2009).

In conclusion, cross-strait relations have witnessed important progress since President Ma Ying-jeou assumed office in May 2008. Economically, the achievement of three direct links, the lifting of the ban on mainland tourists' travel to Taiwan, and the signing of ECFA indicates the deepening economic integration and interdependence between the mainland and Taiwan. Politically, the cross-strait relationship has overcome its air of previous political tension created by the secessionist activities of former Taiwanese President Chen Shui-bian and the DPP government. Since May 2008, both the current Taiwan's ruling party, the KMT, and the CCP leaders have shown conciliatory and positive postures towards one another.

\section{Summary}

To sum up, cross-strait relations have undergone four periods of development as follows. The time from 1949 to 1979 was the era of military confrontation period between mainland China and Taiwan. There was no political, economic and social contact between people across the Taiwan Strait. From 1979 to 1993, cross-strait political contact emerged with the mainland's issuing of the Message to Taiwan Compatriots as a turning point in the mainland's policy towards Taiwan. Also in this period, cross-strait economic and social communication started to grow significantly. In the period from 1994 to 2007, cross-strait political relations deteriorated dramatically due to Taiwanese leaders, such as Lee Teng-hui and Chen Shui-bian engaging in anti-unification and pro-Taiwan independence actions. At the same time, cross-strait economic and social integration further deepened dramatically notwithstanding their ongoing political tensions. The fourth period spans the time since Taiwan President Ma Ying-jeou assumed office in May 2008 to today, in which the cross-strait economic and political relationship has witnessed a historical milestone with the rapid economic improvements between the mainland and Taiwan, the realization of the three direct links, the achievement of the authorisation for mainland's tourists to travel to Taiwan and the signing of ECFA. 


\section{Chapter 3 Literature Review: Realism, Liberalism and}

\section{Interdependent Theory with Cross-strait Relations}

\section{Introduction}

As mentioned previously in Chapter One, the study of whether and how economic interdependence affects states' political relations is not a new topic in international relations. After a brief review of the existing literature, it is obvious that liberalism and realism hold different views towards whether economic interdependence leads to peace or conflict. This chapter begins with a general review of the literature of contrasting realism and liberalism. In particular, the following few sections will summarise and critique some theories, such as classical/structural realism, neoliberalism and interdependence.

\subsection{Classical \& Structural Realism with Cross-strait Relations}

Classical realism has a long historical and philosophical tradition. Its thoughts can be traced back to 2,500 years ago. Early classical realist thinkers, such as Thucydides, Niccolo Machiavelli, Carl von Clausewitz, and Hans J. Morgenthau were concerned with questions such as power, order, justice and change at the domestic and international levels (Lebow, 2007, p.53). Classical realist ideology in general is based on the view that individuals/states are primarily selfish and power seeking. The realists believe that the international system is anarchic and there is no authoritative hierarchy. The nature of an anarchic international system derives originally from Thomas Hobbes' Leviathan, wherein Hobbes describes states within international anarchy are "having their weapons pointing, and their eyes fixed on one another" (Hobbes, 1968, p.187). In the classical realist world, states operate in a self-help world as there is generally no higher authority they can turn to if they are threatened. Therefore, states have to rely on themselves to safeguard their security. One of the 
main goals of states is survival. To the realist, the key subject of international politics is power. This idea appears in Thucydides' History of the Peloponnesian War in which Thucydides strongly emphasized the importance of pursuing power "the strong do what they have the power to do and the weak accept what they have to accept" (Thucydides, 1972, p.42). After World War II another important classical realist scholar was Hans J. Morgenthau. His textbook Politics among Nations: the Struggle for Power and Peace was described by Karen A. Mingst as "the realist Bible for the years following World War II" (Mingst, 2008, p.65). For Morgenthau, world politics is a struggle for power, and the balance of power has contradictory implications for peace. It may not only deter war, but also intensify tensions and make war more likely under different circumstances based on the power struggle between the status quo powers and the rising challengers (Morgenthau, 1973).

In the late 1970s, realist theory underwent a supplementary development when Kenneth Waltz devised the theory of structural realism which is also widely referred to as neorealism. Consistent with the theory of classical realism, structural realism also holds the view that world politics are dominated by power and the international system is anarchy. However, structural realists believe that the structure or architecture of the international system is the most important unit from which to study world politics and it affects the likelihood of war. Structural realists argue that the polarity of the system, when balanced or imbalanced induces a power shift within the international system, has the greatest influence on the prospect of war between states (Mearsheimer, 2007, p.78-82). Structural realism also believes that the possibility of international cooperation is slim because of the potentially uneven distribution of benefits among participating states. In the book Theory of International Politics, Kenneth Waltz describes the situation in which when the possibility of cooperation for mutual gain appears between states, instead of asking "Will both of us gain?", states are more interested in "Who will gain more?". If an expected gain is divided unevenly, the state that gains more will use its disproportionate gain to implement a policy intended to damage or destroy the other. Because of the fear of how the other will use its increased capabilities, states hesitate to cooperate even though the potential gain 
through cooperation is promising (Waltz, 1979, p.105).

To relate realist theory with cross-strait relations, one argues that it is outdated and cannot explain the current situation across the Taiwan Strait. Firstly, both classical realism and structural realism are power-seeking. From their perspective, cross-strait relations are power-based and the more Taiwan's economy depends on mainland China, the more severe threat the mainland can pose to Taiwan's national security (see Leng, 1998 \& Friedberg, 1993). However, this approach is limited because it only focuses on the military and political contribution to a nation's national power, but omits the importance of economic forces. Therefore, the realist theory which mainly focuses on the military and political areas fails to expand on the current cross-strait relationship which can be defined as deeper economic and social integration with the emergence of political contacts. Secondly, based on international anarchy and states' pursuit of absolute/maximal gain, structural realism deems that there is only a limited chance for international cooperation. However, recent development across the Taiwan Strait such as ECFA - a conduct of mutual cooperation between SEF and the ARATS works very well between the mainland and Taiwan. Cross-strait agreements, such as ECFA, show that institutions and organisations can work between the two sides and that also poses another challenge to structural realism. The next few sections will take a closer look at some liberal theories and discuss how the liberal theories can be applied to cross-strait relations.

\subsection{Neoliberalism with Cross-strait Relations}

Neoliberalism which developed from the early 1980s (Martin, 2007, p.110) is a relatively new theory in international relations. Stephen D. Krasner's edited a book titled International Regimes (Krasner, 1983) and Robert O. Keohane's book After Hegemony: Cooperation and Discord in the World Economy (Keohane, 1984) marked the emergence of neolibearalist theory. For the neoliberal theory and neoliberals, the central focuses in world politics are international organizations and institutions. Neoliberalism is also referred to as neoliberal insitutionalism. This thesis will use the term neoliberalism, but this does not indicate any differences between the two labels. 
Similar to realist theories, neoliberalism also argues that world politics are in a state of anarchy. However, cooperative international arrangements can be achieved through coordination and collaboration between states. Why do states choose to cooperate in an anarchic international system? Neoliberalist scholars use the prisoner's dilemma to prove that it is in an individual state's self-interest to achieve cooperation. The prisoner's dilemma is a concept of game theory about two prisoners who are arrested by the police. Because the police have insufficient evidence for a conviction, both of the prisoners are separated in different rooms and interrogated separately for an alleged crime. The interrogator tells each prisoner that if one of them confesses and the other does not, the one who confessed will go free and the other who kept silent will get a long prison term. If both confess, both will get reduced prison terms. If neither confesses, both will receive short prison terms because of the lack of evidence. What will the prisoners choose to do? Obviously both prisoners will try to maximize their advantage by cooperating with or betraying the other player. Let's imagine if both prisoners confess, thus each of them will serve a longer sentence than if both of them cooperated and kept silent. It is a difficult decision for each prisoner to make because neither knows how the other will respond (Mingst, 2008, p.61-62). The prisoner's dilemma is important in neoliberalist theory as it reveals two facts in international relations. Firstly, one of the most important reasons why states choose to cooperate is because of mutual benefit, known as reciprocity. Robert $\mathrm{O}$. Keohane has mentioned in his book After Hegemony: Cooperation and Discord in the World Economy that "reciprocity seems to be the most effective strategy for maintaining cooperation among egoists" (Keohane, 1984, p.214). Secondly, the prisoner's dilemma in international relations reveals the fact that the impediments of international cooperation do not constitute international anarchy itself, but individual states' behaviour of cheating, reneging on the terms of trade agreements, and the misunderstanding of information. According to a neoliberalist scholar, Arthur A. Stein, international cooperation can be achieved through institution-building which can specify and distinguish states' behaviours between cooperation and cheating (Stein, 1983). In order to pursue mutual interests, states' efforts of coordination and 
collaboration will slowly have the effect of driving the emergence of international institutions.

International institutions are defined as "a set of rules and stipulate the ways in which states should cooperate and compete with each other. [International institutions] prescribe acceptable forms of state behaviours, and proscribe unacceptable kinds of behaviours" (Mearsheimer, 1994-1995, p.8). Even though international institutions do not rise to the level of a form of world government, states must choose to obey the rules if they wish to gain mutual benefits from joining international institutions. Scholar John J. Mearsheimer summarised four reasons why international institutions can produce cooperation among states. Firstly rules within institutions can increase the number of transactions between states over time. The institutionalised iteration creates a situation in which the cost of cheating today becomes so high that the potential future punishment will occur in the future cooperation. Therefore, international institutions have a role of discouraging state's cheating behaviour. Secondly, international institutions create a situation in which interactions between states are in different issue areas. States become reluctant to cheat in one issue area because they fear that the victim and other states will retaliate in another issue area. Thirdly, the structure of international institutions increases the amount of information available to cooperating states so that close monitoring becomes possible. Institutions can perform monitoring functions and can provide assurance that other states are obeying the terms of their commitments. Fourthly, rules within institutions can reduce the transaction costs of individual agreements. Therefore, international institutions become more profitable and more attractive for self-interested states (Mearsheimer, 1994-1995).

To relate neoliberalism with cross-strait relations, one argues that neoliberalist's focus on institutions can best explain recent cross-strait relations as it suitably reflects the experience of cross-strait relationship in the past three decades. In particular, the establishment of two semi-official organisations - SEF and ARATS - in the beginning of 1990s marked the emergence of cross-strait cooperation and the institution-building process. Cross-strait institution building in the early 1990s is an 
important event because through negotiations between SEF and ARATS, there is more information available for both sides. Having an institutional channel to contact the other side across the Taiwan Strait, clear information exchanges between both the mainland and Taiwan become facilitated. Therefore, misunderstanding between them can possibly become avoidable. In this sense, cooperation between the mainland and Taiwan becomes possible and efficient. As mentioned in Chapter Two, in order to soften cross-strait political tension, the "1992 consensus" was achieved between the SEF and ARATS negotiations. Furthermore, after the KMT came back to power again in 2008, the achievement of the Three Direct Links and ECFA further proves that cooperation between the mainland and Taiwan can be efficiently achieved through negotiations and institutions. Chapter Four will offer a closer examination of ECFA between the mainland and Taiwan, and shall explore the functions of institutions between the two sides.

\subsection{Interdependence Theory with Cross-strait Relations}

Interdependence theory is a relatively new theory and an important element in the theory of liberalism. In Robert O. Keohane and Joseph S. Nye's book Power and Interdependence, the authors firstly explicitly assert the fact that "we live in an era of interdependence" (Keohane \& Nye, 1989, p.3). Then Keohane and Nye point out that interdependence as an analytic concept can be most simply defined as mutual dependence. In order to understand the role of power and interdependence, Keohane and Nye also point out two important dimensions of interdependence, which are sensitivity and vulnerability (Keohane \& Nye, 1989). According to Susan M. McMillan, "sensitivity is the extent to which one country is affected by the actions of another, whereas vulnerability is the extent to which a country can insulate itself from the costly effects of events that occur elsewhere" (McMillan, 1997, p.34). In world politics, interdependence refers to a situation characterised by reciprocal effects among countries or among actors in different countries. Another scholar David A. Baldwin's definition of interdependence refers to an "international relationship that would be costly to break" (Baldwin, 1980, p.484); this is similar to Keohane and 
Nye's idea.

In international relations, the study of interdependence shows that economic interdependence has the positive effect of reducing conflict between trading partners and leading them to peace and stability. The liberal argument that connected economic interdependence with less war is based on the idea that international commerce restrains individual state's passion for conquest. In the book The Passions and the Interests, Albert $\mathrm{O}$. Hirschman argues that "international commerce, being a transaction between nations, could conceivably have also a direct impact on the likelihood of peace and war: once again the [economic] interest might overcome the passions, specifically the passion for conquest" (Hirschman, 1977, p.79). Some other liberal scholars such as Peter Cain, Richard Rosecrance, and John Mueller's approach to how and why economic interdependence leads to peace between states is worthy of investigation. The next few sections of this chapter will summarise some ideas of interdependence theory and briefly relate it to cross-strait relations.

As mentioned above, interdependence theory is a newly-developed strand of liberalist theory. In terms of the relationship between economic activities and the result of war, liberalism in general makes the positivist argument that "an open international political economy, with rules and institutions based on state sovereignty, provides incentives for international cooperation and may even affect the international constitutions of states in ways that promote peace" (Koehane, 1990, p.166-167). The theory of interdependence proposes that economic interdependence decreases international conflict, or at least decreases incentives for conflicts. Among the theories, divergent causal arguments between interdependence and peace coexist. This chapter will discuss three casual mechanisms, known as the cost-benefit mode, the free trade mechanism and the sociological model.

Richard Rosecrance devised the cost-benefit model to analyze the relationship between economic interdependence and conflict. According to Rosecrance, a liberal open economy is a prerequisite to increased trade. As trade increases in a system and interdependence grows, the initiation of war becomes a relatively costly way for states to pursue their interests. Within the system of high interdependence, trading states 
realise they can improve their national power more easily through commerce in the international market rather than through military expansion. In other words, in the world of interdependence, economic means can be more effective than military ones in achieving a given purpose. Therefore, high interdependence will lead to peace because trade brings more benefits to a state than invasion. In this book The Rise of the Trading State: Commerce and Conquest in the Modern World, Richard Rosecrance reveals the trend towards trading worlds rather than a military-political world. In order to prosper, nations need to shift in the direction of new trading strategies (Rosecrance, 1986, p.212-214).

Another causal argument between interdependence and the reduction of war is from the free trade mechanism. In Peter Cain's work Capitalism, War and Internationalism in the Thought of Richard Cobden, Cain summarises two ways free trade helps end warfare between states. Firstly, free trade helps by undermining the income and position of the ruling landlord class. Without financial support, aristocrats are unable to mount a possible and effective military fight. Secondly, free trade creates a situation in which states are connected through a high level of trade, capital flows and there is an international division of labour. Within the system of high interdependence, states are unlikely to go to war against each other because they recognise that their own wealth and prosperity depend on others. Economic interdependence helps to promote peace because the disruption of commercial ties by war will not serve a state's national interest (Cain, 1979, p.233-239).

Another causal argument between interdependence and peace comes from the sociological model, scholar Ronald Rogowski's new coalition building idea and John Mueller's social and cultural evolution process. Ronald Rogowski argues that interdependence facilitates sociocultural evolution between trading states. Closer economic ties will generate new coalitions with different international goals. If economic interdependence is intensive, these new coalitions will grow larger and will have the ability to influence state goals (Rogowski, 1989). In the book Retreat from Doomsday: the Obsolescence of Major War, John Mueller emphasises the importance of sociocultural evolution for reducing international conflict. Mueller summarises the 
process by which war is abandoned by people. In the first stage of the process of social and cultural evolution, war is rejected because it's calculated to be ineffective and/or undesirable. War in this process is defined as "rationally unthinkable". In the second stage of the evolution, war is rejected again not because it's a bad idea, but because it remains subconscious and never comes up as a coherent possibility. War in this process is defined by Mueller as "subrationally unthinkable" between trading states because their needs, desires and concerns are broader than military concerns. Therefore, Mueller has concluded that if the idea of war initiation fades as the historical abandonment of duelling and slavery, war "may be obsolescent" and peace "can prove to be habit forming, addictive" (Mueller, 1988, p.240-244).

To relate interdependence theory to cross-strait relations, one discovers that the argument connecting economic interdependence with less war is highly applicable to the current cross-strait relations. Firstly, the interdependence of trade between mainland China and Taiwan has been greatly enhanced in the past three decades. China has been Taiwan's top investment destination for many years since the early 1990s (Chung, 2008). As mentioned in Chapter One, the cross-strait economies are gaining so much momentum that the mainland has replaced the United States to become Taiwan's largest trading partner in 2003. Daily increasing cross-strait economic interdependence creates a situation in which any kind of disruption, such as cross-strait military conflict would disrupt interdependence and thus affect mutual benefits of both sides. Therefore, the initiation of conflict becomes a costly way for both the mainland and Taiwan to pursue their interests. This conception perfectly fits in with Richard Rosecrance's cost-benefit model for analysing the relationship between economic interdependence and conflict.

Secondly, the current cross-strait economic interdependence accords with the argument about free trade's ability to mitigate warfare between states. As mentioned in Chapter One, ECFA was signed in June, 2010. With its aims to reduce tariffs and commercial barriers between the mainland and Taiwan, ECFA is assumed/considered a cross-strait free trade agreement. As ECFA further comes into practice, the mainland and Taiwan will be further connected through a higher level of trade, capital flows and 
an international division of labour. Therefore, the mainland and Taiwan are unlikely to go to war with one another because mainland China's own wealth and prosperity depends on Taiwan's. Chapter Four will offer a closer examination of ECFA and its enforcement.

Thirdly, the sociological argument relating interdependence to less conflict offers another explanation of the current cross-strait relations. The sociological model emphasises the importance of the links among people. This idea corresponds to Taiwanese scholar Yung Wei's concept of "linkage communities". According to Wei, the extent of "linkage communities" can be used to illustrate the actual process of functional integration that occurs through extensive networks of personal contacts formed across the Taiwan Strait. Wei argues that, despite prolonged stalemate and occasional crises in the Taiwan Strait, gradual but persistent functional integration has been a constant ongoing process across the Taiwan Strait. In addition, both Taipei and Beijing have made various structural adjustments and accommodations in the forms of rules and mechanisms so as to permit continuing socio-economic exchange between the two sides. Wei also advances the hypothesis that political integration will be rendered much easier if there are sizable and substantive linkage communities already in existence on either side of a partitioned society (Wei, 2004). Furthermore, Wei's "linkage communities" idea gains support from Kevin Tze Wai Wong, who studies Taiwan's emerging class rift which is the result of the impact of cross-strait economic integration. According to Wong, in Taiwan, class groups with more skills that benefit from cross-strait economic integration tend to support the pan-blue camp which urges further cross-strait economic ties and eventual reunification, whereas the less skilled who are harmed by cross-strait economic integration, are more willing to vote for the pan-Green camp which is opposed to cross-strait economic integration and in favour of Taiwan independence (Wong, 2010). It is logical to speculate that the more people benefit from cross-strait integration, the more support the pan-Blue camp will gain. Therefore, a final reunification between the mainland and Taiwan becomes feasible through sociological evolution across the Taiwan Strait. Wong's research shows that cross-strait economic integration has contributed to class rift in Taiwan 
which precisely corresponds with Ronald Rogowski's new coalition building idea and John Mueller's social and cultural evolution process as mentioned above in this chapter.

\section{Summary}

In conclusion, the realist theory, both classical and structural fails to explain the current cross-strait relationship for two reasons. Firstly, realist theory focuses on power, mainly military power, and it omits the importance of economic and social exchanges between the mainland and Taiwan. Secondly, structural realism denies the high possibility of international cooperation. However, the cooperation between SEF and ARATS has already borne fruit which greatly challenged structural realism.

Liberalism on the other hand proves to be more applicable to the current cross-strait situation. First, neoliberalism focus on institution building provides both the mainland and Taiwan with more possible channels to contact the other side across the Taiwan Strait. Therefore, misunderstanding becomes avoidable. In this sense, cross-strait institution building is beneficial to prevent and reduce cross-strait military conflict. Second, the current economic interdependence between mainland China and Taiwan meshes perfectly with the theory of interdependence, which argues that economic interdependence decreases international conflict and has the positive effect of leading trading partners to peace and stability. 


\section{Chapter 4 Assessing Cross-strait Relations through ECFA}

\section{Introduction}

As previously mentioned, since Ma Ying-jeou took office in May 2008, cross-strait relations have experienced a historic turning point. Cross-strait exchanges and cooperation in economics and trade have become ever closer. Both the mainland and Taiwan have realised that, as important trading partners, neither side should distance itself from the trend towards global and regional economic cooperation. The desire of people on both sides of the Taiwan Strait has been growing with respect to establishing institutional economic cooperation (Chinese Radio Network, 2010). It is in this context that mainland China and Taiwan signed the Economic Cooperation Framework Agreement (ECFA) in Chongqing on $29^{\text {th }}$ June, 2010.

This chapter first introduces the detailed contents of ECFA in order to help readers gain a better understanding of the importance of signing ECFA. A comparison of the economic motivations for China and the US to join the Asia-Pacific Economic Cooperation (APEC) follows. The research into this comparison is offered in the hope that it provides inspirational insights on interpreting the trend of cross-strait economic relations under the mechanism of ECFA. Finally, this chapter will apply Neoliberalist Theory and the Economic Interdependence Theory to explore the significance of this economic agreement, ECFA, to peace and stability across the Taiwan Strait.

\subsection{Content of ECFA}

In total, ECFA consist of 5 chapters and 16 articles. The entire text consists of a mere 2,900 Chinese characters. The text includes a Preamble, Chapter 1 General Principles, Chapter 2 Trade and Investment, Chapter 3 Economic Cooperation, Chapter 4 Early Harvest, Chapter 5 Other Provisions and five Annexes (Annex I, Product List and Tariff Reduction Arrangements Under the Early Harvest for Trade in Goods, Annex II, Provisional Rules of Origin Applicable to Products Under the Early Harvest for Trade in Goods, Annex III, Safeguard Measures Between the Two Parties Applicable to Products 
Under the Early Harvest for Trade in Goods, Annex IV, Sectors and Liberalisation Measures Under the Early Harvest for Trade in Services and Annex V, Definitions of Service Suppliers Applicable to Sectors and Liberalisation Measures Under the Early Harvest for Trade in Services). ECFA covers main economic activities across the Taiwan Strait, including complementing and perfecting the existing mechanism, visualising and exploring future cooperation, evading possible risks and settling disputes (China News, 2010a).

After gaining a brief understanding of the text of ECFA, the next few paragraphs will introduce the core content of its text and some important issues relative thereto.

\subsubsection{Opening Markets for Trade in Goods and Services}

The terms of trade in goods mainly includes the Early Harvest Programme which lists the commodities and the process of tariff reduction in the initial phase and market accesses between mainland China and Taiwan. According to ECFA terms of trade in service, the mainland and Taiwan agree to negotiate on market access for the trade in services, include formulating a negating schedule, and consider the question of normalising trade in services between the mainland and Taiwan and those items not to be opened between cross-strait trade (Zhang, 2010).

\subsubsection{The Early Harvest Programme}

The Early Harvest Programme means the prior realisation of tariff reduction and exemption between the mainland and Taiwan before the two sides complete their negotiation on trade in goods (Tian, 2010). After adjustment to achieve the complementarity of their respective industries and with full consideration of the concerns of the other side, the mainland and Taiwan issued the list of the Early Harvest Programme which includes a large number of items with wide coverage.

Regarding trade in goods, Taiwan has 539 items among the Early Harvest Programme, involving13.83 billion US dollars. To compare this number with that of the mainland, it has a 2.02 times larger number of items involved, and a 4.84 times 
larger sum involved than the mainland. The Early Harvest Programme mainly encompasses the Taiwanese enterprises in the traditional industries of petrochemical, machinery, textile, and automobile spare parts. It also includes the products of 17 disadvantaged industries and 18 items of agricultural and fishing products that solely export to the mainland. In return, Taiwan reduces tariffs on 267 items of original products of the mainland, which fall into four categories: petrochemical products, mechanical products, textile products and other products. In addition, within two years after the implementation of the Early Harvest Programme, both sides agree to follow a three-step approach to gradually realising the goal of a mutual zero tariff on the products listed in the Early Harvest Programme (Hu, 2010).

In the area of trade in services, the mainland will expand and open its eleven service industries for Taiwan, including accounting, computer and its related services, research and development, conferences, professional design, import quotas for movies, hospitals, the maintenance of civil aircraft, banking, securities and insurance. With regard to opening the banking industry to Taiwanese enterprises in the mainland which the Taiwanese enterprises concern the most, the mainland will issue six specific measures to facilitate the convenience of Taiwanese-financed enterprises, including allowing Taiwanese banks to establish commercial branches and special financial services institutions for small businesses. Taiwanese banks that have operated on the mainland for more than one year and made profits one year prior to the application can apply to operate RMB (mainland Chinese currency). Taiwan will gradually open nine other service industries, including research and development, conferences, exhibitions, special product design, import quotas for movies, brokers, sports and other entertainment, airline computer reservation systems and banking services (Wang, 2010c).

\subsubsection{Dispute Settlement and Relief}

Currently, the two-conference negotiation mechanism which involves all economic fields between the mainland and Taiwan can no longer adapt to the future cross-strait economic institutionalisation development under the framework of ECFA. Thus, both 
the mainland and Taiwan increasingly need a special body responsible for negotiating and operating. For this reason, ECFA has specially included the "Institutional Arrangement" clause to secure the establishment of a "Cross-strait Economic Cooperation Committee" (Wang, 2010b). This Committee shall convene a meeting every six months and an interim meeting can be organised when necessary, per the approval by both sides. The Committee shall consist of representatives appointed by both the mainland and Taiwan, and be responsible for handling matters relevant to ECFA. It is proposed that this committee undertake five tasks. Also, the committee sets the rule that, according to the mainland and Taiwan's requirements, the committee can constitute a working group to deal with ECFA related issues in specific fields. It is safe to claim that the text of ECFA not only confirms the negotiating institution and the operational functions for ECFA in the future, but also provides legal protection for the establishment and implementation of negotiation institutionalisation across the Taiwan Strait.

The above explanation clearly indicates that the Early Harvest Programme is the core content of ECFA and its essence is based on the principle of reciprocity to promote and facilitate cross-strait free trade through trimming tariffs. The essence of ECFA is further shown in its Preamble, which explicitly states that "[this Agreement] aims to gradually reduce or eliminate barriers to trade and investment for each other, create a fair trade and investment environment, further advance cross-strait trade and investment relations ... and establish a cooperation mechanism beneficial to economic prosperity and development across the Strait" (China News, 2010a). Therefore, ECFA has become a special economic cooperative arrangement to normalise, institutionalise and liberate the economic ties across the Taiwan Strait. Moreover, ECFA not only determines the basic structure and development planning for future cross-strait economic cooperation, but also provides a legal basis for the establishment of free trade zone across the Taiwan Strait. To summarise ECFA marks a significant beginning of cross-strait economic integration.

\subsection{A Comparison of Sino-US Relations under the APEC Mechanism with}




\section{Cross-strait Relations under ECFA Mechanism-Similar Economic Motivations}

APEC as an engine for promoting free trade, and economic and technical cooperation in the area of Asia and the Pacific, has developed to an organisation which has twenty-one members, nearly $40 \%$ of the world's total population, and more than $50 \%$ of the global GNP since its establishment in 1989. With its trade volume accounting for over $40 \%$ of the gross global trade, APEC has become an organisation that leads the development direction of the Asia-Pacific economies (Yang, 2011). Having such distinct benefits, APEC has become an attractive mechanism for more members to join. In sum, the cooperative and operational mechanism of APEC has greatly promoted its members' extensive cooperation in investment, trade, technology and politics.

For China and the US, APEC is a reasonable way for them to ease conflicts, enhance understanding and reach consensus. A scholar has commented that "Without APEC - a multilateral organisation which creates a natural and convenient opportunity for leaders from China and the US to have meetings together, the China-US relations are likely to suffer more twists and turns" (Li, 2002, p.19). In the trend of economic globalisation, China and the US, both as important economies in the international market have entered into a situation in which the closer their relationship is the more economically interdependent they become. Facilitated by the APEC mechanism, bilateral economic exchanges and trade between China and the US made great progress in the 1990s (regarding the growth of China-US trade under the APEC mechanism, see Figure 1 and Figure 2). 
Figure 1 China's Imports \& Exports to and from the US from 1990 to $1999^{1}$
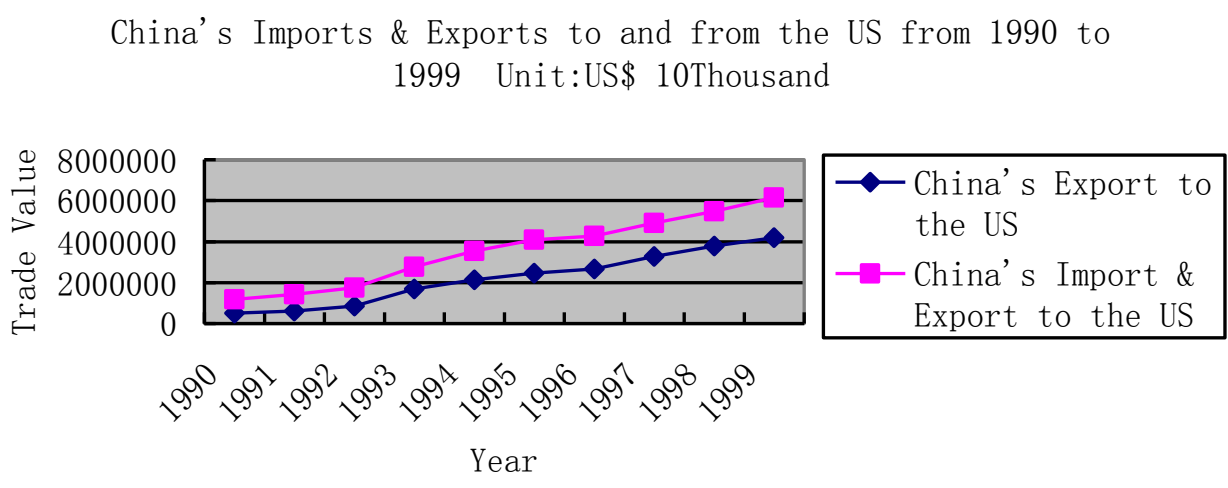
Export to the US

Year

Figure 2 China's Imports \& Exports to and from the US from 1984 to 2000 (by Customs $)^{2}$

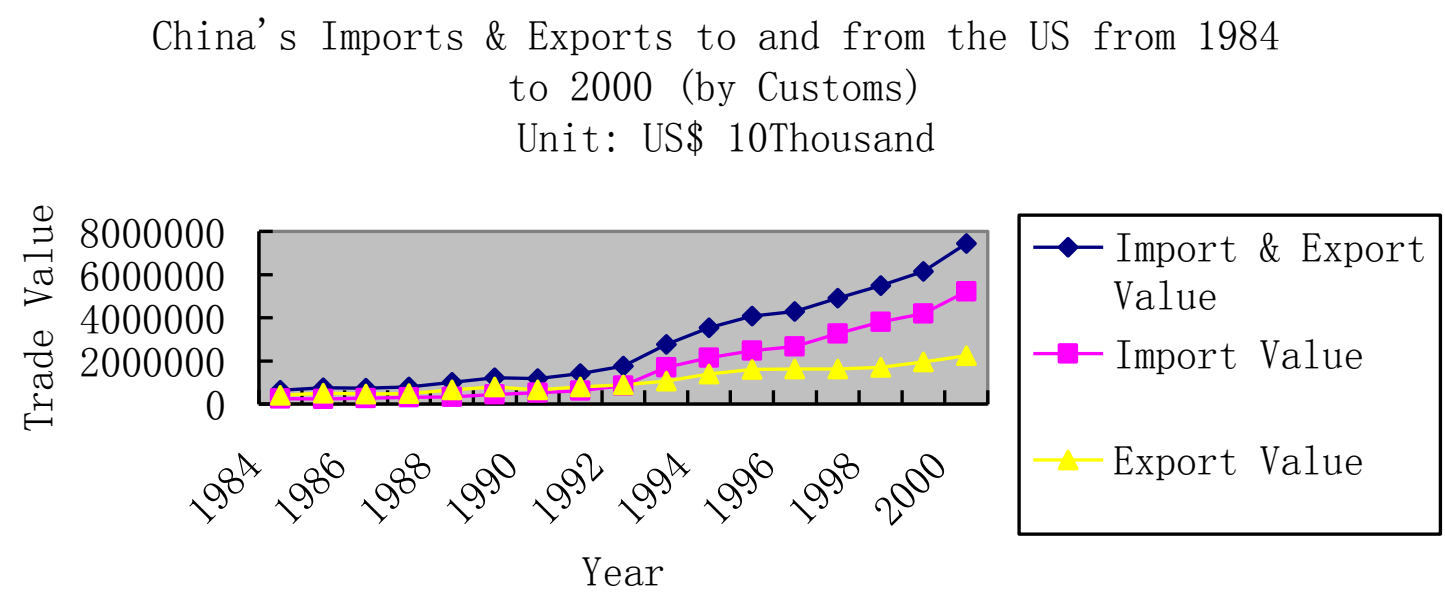

The facilitation mechanism of APEC for Sino-US relations is not the focus of this chapter. In fact, quite a number of scholars have conducted special studies on how

\footnotetext{
${ }^{1}$ Data Source: National Statistical Bureau, China External Economic Statistical Department. China External Economic Statistical Yearbook Database. Accessed November 2011,

http://tongji.cnki.net/kns55/Navi/HomePage.aspx?id=N2006090328\&name=YDWJJ\&floor=1.

${ }^{2}$ Data Source: National Statistical Bureau. China Statistical Yearbook Database. Accessed November, 2011, http://tongji.cnki.net/kns55/Navi/HomePage. aspx?id=N2010100096\&name=YINFN\&floor=1.
} 
much and to what extent China-US trade has had an impact on the two countries' political relations, but they will not be repeated here. However, APEC has played an active role in Sino-US relations. Therefore, an investigation of the context under which China and the US joined APEC provides an instructive and significant discussion for readers to understand the impact of ECFA on cross-strait economic relations.

\subsubsection{APEC, China and the US}

After the Cold War, the world entered a new era of globalisation and regionalisation which revolved around economic interests and focused on peace, cooperation, and common development. In a sense the globalisation of economy can be characterised as a gradual process of perfecting the global market after countries open their own markets. This process inevitably leads to economic regionalisation, which will develop from small-scale regionalisation to large-scale regionalisation and finally towards economic globalisation (Chen \& Cui, 2006).

According to some scholars, such as Liu Ke and Zhang Xing, there are three main economic motivations inducing the US to have become a founding member of APEC and actively promote its development. These motivations included the deterioration of the US domestic economy, the change of world economic centres, and the competition and pressure from Japan and the regionalised Europe (Liu, 1996; Zhang \& Liu, 2000).

Firstly, two pillar industries of the US economy, the automobile and steel industries, encountered setbacks in competition and their situation deteriorated. In the 1980s Japanese automobiles swarmed into the US market, increasing the pressure on the US auto industry. Around the same time, due to the fast development of the Japanese semiconductor industry, the US lost its monopoly position in the global market and was reduced to secondary status. The decline of the US semiconductor industry directly led to the downfall of the US electronic industry. As a result, the US competitive advantage in certain high technology industries was also greatly weakened (Liu \& $\mathrm{Zu}, 2011)$. 
Secondly, the Asia-Pacific region had made remarkable development in the economic field since the 1950s when the rise of the Japanese economy began. The global economic centre has shifted from the Atlantic Ocean to the Pacific Ocean (Cheng, 1996). Therefore, the US government started to pay intense attention to the development in the Asia-Pacific region. More importantly, at that time the US already became the main export market for Asia and therefore the US considered Asia-Pacific region as a significant new market to be explored. Bilateral economic bonds between the US and Asia-Pacific region was on the increase. The former US President Bill Clinton repeatedly emphasised that, "more than half of American employment relies on foreign trade, among which $40 \%$ relies on the Asia-Pacific region" (Yuan \& $\mathrm{Li}$, 1997, p.37).

Lastly, the formal launch of the European common market and the gradual process of European political integration not only weakened the US political impact on Europe, more importantly the US economic interests were pressed by rivalry from Europe. However, in Asia due to its geographical proximity, Japan carried out a strategy of "to separate Japan from Europe back to Asia" which aims to expand its influence in Asia by increasing its exports and investment to Asian Countries. At the same time, the trend of allying Asian countries and gaining strength had non-stop development in East Asia. ASEAN carried out a neutral strategy to balance between the US and Japan therefore gained dominance in the areas of politics, economy and foreign affairs within the region of Southeast Asia (Liu, 2009).

Therefore, in order to contend with the increasingly stronger European Union and Japan, and to consolidate its leading position in Asia and realise its economic strategy, the US changed its strategy in Asia and Pacific regions in the 1990s. The US tried to recover its own economy by benefiting from the economic vitality in the Asia-Pacific region and by opening the economic market in East Asian countries. Therefore, the US government advocates free trade and actively promotes the establishment and development of APEC. The US government considers it necessary to actively participate in APEC, and only by doing so can it realise objectives unlikely to be reached though bilateral negotiations, thus promoting the process of trade and 
free investment. In particular, as the largest developing country in the Asia-Pacific Region, China's economy has been burgeoning since it adopted the policy of reform and opening. Furthermore, China has enormously rich human resources with low wage levels, which is good for developing labour-intensive industries which supplement the trade structure of the US. As a result, the US changed its policy towards China and started to actively incorporate China into the community.

As for China, its foreign trade soared from the year in which its government proposed reform and opening as the policy of state governance to the year in which China joined the APEC, or from 1980 to 1991. In 1980 China's gross volume of import was $\$ 38.14$ billion; this increased to $\$ 69.60$ billion in 1985; in 1988 it reached \$ 102.7 billion, breaking the record of \$100 billion. In 1991 it attained \$ 135.70 billion (Zhao, 2002).

However, when China's reform had progressed to a certain point, the urgent question arose as to how to ensure the continuation and enhancement of its reform and opening policy by working on its economic environment. Moreover, China's reform and opening had been accompanied by growth in its foreign trade. In other words, the continuation of China's economic growth could not be sustained without corresponding growth in its foreign trade. Consequently, China had to integrate into the international economy for the sake of its development. In a time where protectionism and regionalisation had been developing and its trade frictions with other countries increasing in both breadth and depth - especially those with the US - if China intended to continually develop its foreign trade, it could no longer rely solely on unilateral trade agreements, but had to participate in bilateral and multilateral economic cooperation (Lu, 1997).

Nevertheless, China encountered great difficulties when trying to join the WTO. Since $75 \%$ of its foreign trade and $90 \%$ of its foreign investment were concentrated in the Asia-Pacific Region (Guo, 1999), this factor was of significant import in China choosing to join APEC. APEC is a channel for China to intensify its cooperation with other member states - especially the US - and to promote mutual economic dealings. Accordingly, China actively supported the principles of 
multilateral cooperation and the open market of APEC. China also hoped to benefit from the rise of the Asia-Pacific Region and augment its comprehensive national power. Thus China's entry into the APEC is not only consistent with the trend of economic globalisation, but also addresses its demand to maintain the growth of its foreign trade.

To summarise, both China and the US clearly realised that in an era of economic globalisation and political multi-polarisation, the economic interests of both countries increased their mutual reliance as never before. In a certain sense, one country's development contributes to the prosperity of the other; and win-win among countries has replaced the traditional zero-sum game. Though China and the US differ in respect to their resources structures, industrial structures and consumption preferences, the complementarity of their trade structures may be fully utilised by sharing with one another their giant markets, and their respective competitive power may be strengthened by their potential in cooperation. Thus, for both China and the US, actively joining and participating in APEC responded to their respective demands and accorded with their economic interests, under the mechanism of which they were able to engage in economic coordination and exchanges.

\subsubsection{ECFA, the mainland and Taiwan}

Since 1979 cross-strait trade has been growing by a two-digit percentage annually. In 1979 when trading started, the gross volume was merely 80 million US dollars. By 2010, it grew by hundreds of times to 145.37 billion US dollars. The growth rate in average in these three decades was $46.8 \%$ (See Figure 3). In 2003 the mainland replaced the US and Japan as the biggest trading partner of Taiwan; Taiwan also became the second-largest import market for the mainland (Lin \& Yi, 2006). 
Figure 3 Cross-Strait Trade from $1979-2010^{3}$

\section{Cross-strait Trade from 1979 to 2010}

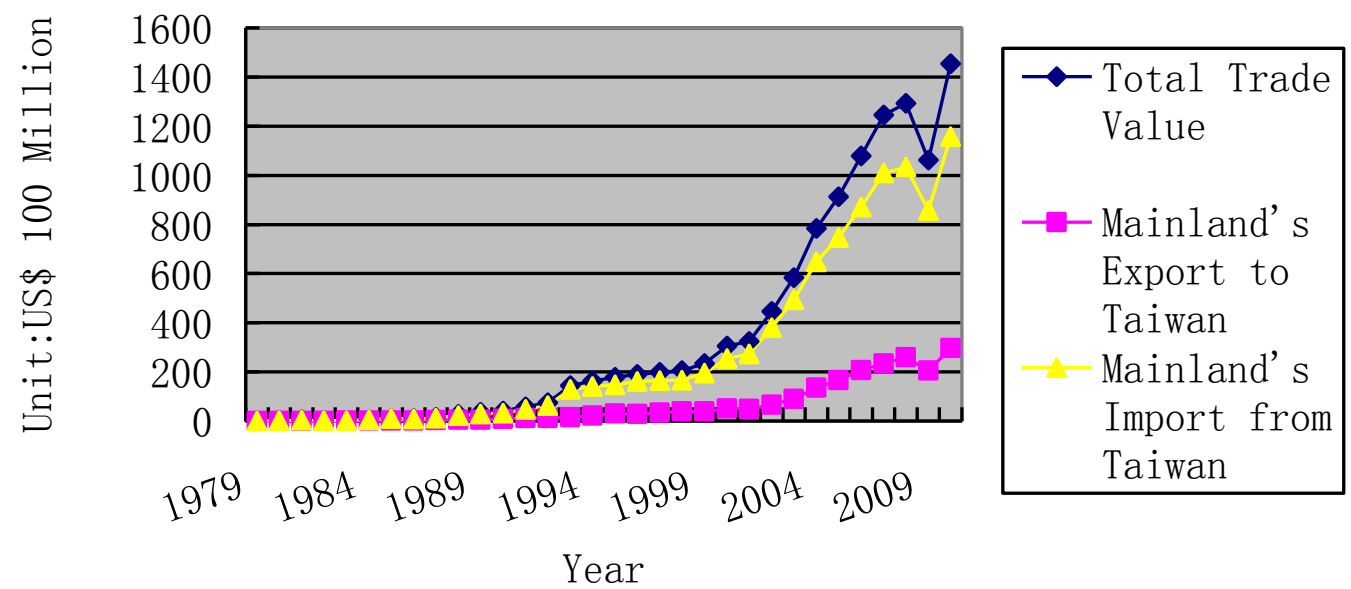

In these years, however, although the gross trading volume has been rising across the Taiwan Strait, the economic position of Taiwan in the mainland's economy has been decreasing. Surprisingly, Taiwan's economic reliance on the mainland has been increasing (See Figure 4).

\footnotetext{
31978 - 2005 Data Source: Taiwan Affairs Office of the State Council PRC. "Statistics Regarding Cross-Strait Trade from 1978 to 2005". Taiwan Affairs Office of the State Council PRC Website. Accessed November 2011, http://www.gwytb.gov.cn/lajm/lajm/201101/t20110121_1718210.htm.

2006 - 2008 Data Source: Taiwan Affairs Office of the State Council PRC. "Statistics Regarding Cross-Strait Trade from 2000 to 2008". Taiwan Affairs Office of the State Council PRC Website. Accessed November 2011, http://www.gwytb.gov.cn/lajm/lajm/201101/t20110121_1718251.htm.

2009 Data Source: Taiwan Affairs Office of the State Council PRC. "Statistics Regarding Cross-Strait Trade and Investment from January to December 2009". Taiwan Affairs Office of the State Council PRC Website. Accessed November 2011,

http://www.gwytb.gov.cn/lajm/lajm/201101/t20110128_1737094.htm.

2010 Data Source: Taiwan Affairs Office of the State Council PRC. "Statistics Regarding Cross-Strait Trade and Investment from January to December 2010". Taiwan Affairs Office of the State Council PRC Website. Accessed November 2011, http://www.gwytb.gov.cn/lajm/lajm/201101/t20110128 1737103.htm.
} 
Figure 4 Cross-Strait Trade Interdependency from 1992 to $2005^{4}$

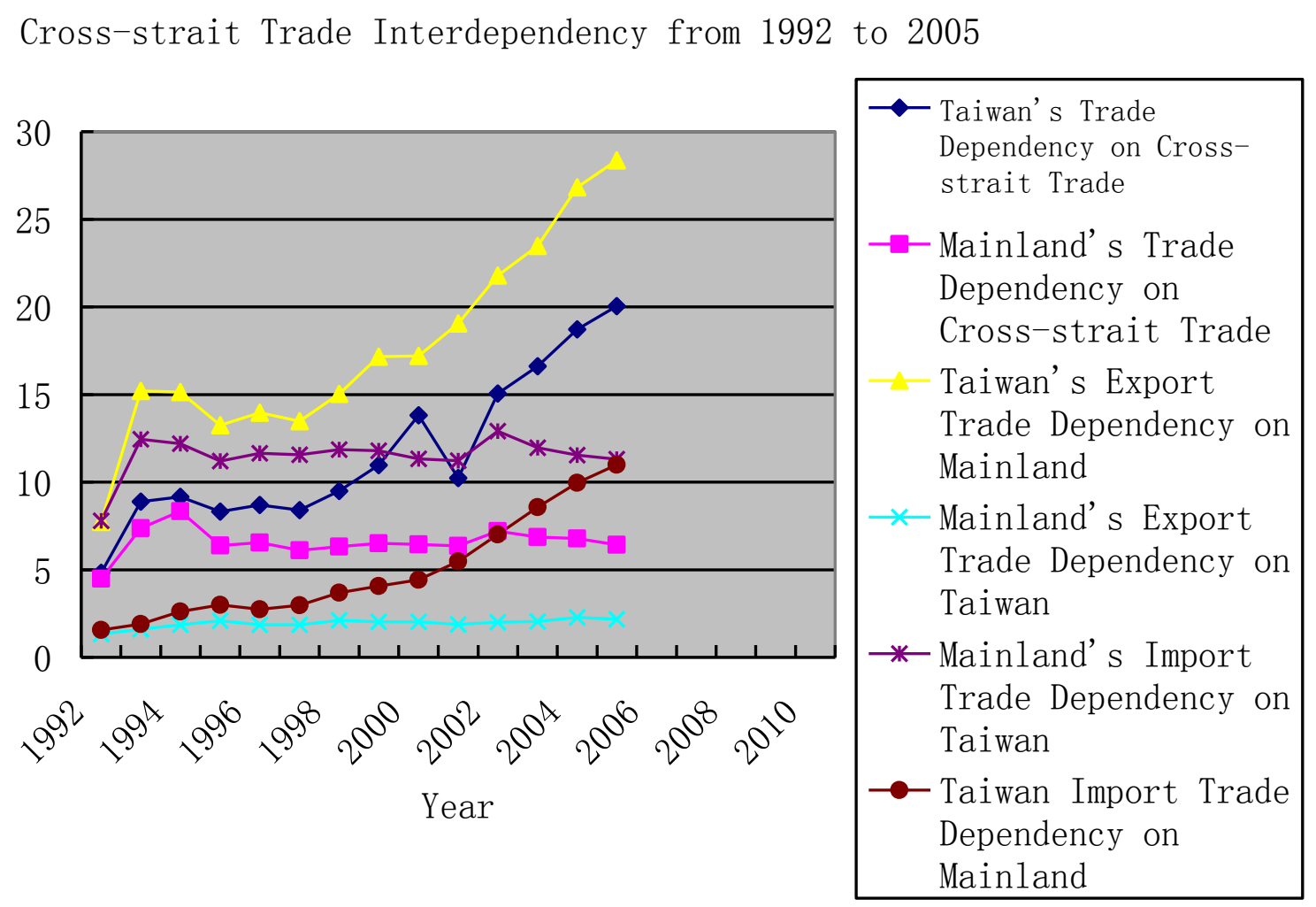

For instance, in 2005 Taiwan had a lower market share in the mainland market than South Korea did; in contrast, products from the mainland occupied more than one-tenth of the gross import of Taiwan (Xiong, 2005). Ma Ying-jeou repeatedly stated that exports to the mainland already exceeded $40 \%$ of Taiwan's gross export (Jin, 2010). According to the latest statistics, from January to October 2010, the gross imports and exports of the Chinese mainland were approximately 2.39 trillion US dollars, in which the trade between the mainland and Taiwan was approximately 118.68 billion US dollars, merely $5.02 \%$ of the foreign trade volume of the mainland. On the other hand, according to Taiwanese statistics, from January to October 2010, Taiwan's gross exports were 226.44 billion US dollars, in which exports to the mainland and Hong Kong were 95.09 billion US dollars, 42\% of Taiwan's gross exports (Wang, 2011). Clearly, in cross-strait trade, the imports and exports of the

\footnotetext{
${ }^{4}$ Data Source: Taiwan Affairs Office of the State Council. "Cross-Strait Trade Statistic and Analysis from 1979 to 2005". Taiwan Affairs Office of the State Council PRC Website. Accessed November 2011, http://www.gwytb.gov.cn/lajm/lajm/201101/t20110121 1718211.htm.
} 
mainland and Taiwan were severely unbalanced, with the trade deficit growing year after year.

Apart from its severe trade deficit with the mainland, Taiwan will also probably be marginalised in terms of regional economic integration. Furthermore, due to political causes, it is very hard for Taiwan to sign a free trade agreement with other countries. In an era of economic regionalisation, this increases the difficulties for Taiwan in exploring overseas markets. In addition, as the relevant agreements of the Chinese mainland with ASEAN enter into effect, Taiwanese industries will suffer high tariff barriers compared with ASEAN nations. As a result, the market for products from Taiwan will be pre-empted by similar products from ASEAN, Japan and South Korea. The resulting heavy losses will imperil Taiwan's economy. The General Association of Industry and Commerce of Taiwan has computed potential losses. From 2010 on, petrochemical products from ASEAN sold to the mainland will enjoy zero tariffs. Without signing ECFA, petrochemical products that Taiwan sells to the mainland will be taxed at tariffs on goods at $5 \%$ to $19 \%$. In such case, Taiwanese products will not be able to compete with those of the ASEAN nations. According to other predictive statistics, without signing ECFA, Taiwan's overall economy will decrease by $1 \%$ (Liu \& Bian, 2009).

Taiwanese society has realised that economic regionalisation is an inevitable trend. While the ASEAN nations have been deepening their economic regionalisation under the goad of the financial crisis, Taiwan confronts material risks of being excluded from the wave of economic regionalisation in East Asia. Therefore, if the Taiwanese economy is to avoid the serious results of decreasing competitiveness, retreat of foreign investors and local enterprises, and a drastic upsurge in the unemployment rate, it must change its attitude towards cross-strait economic and trade cooperation.

The mainland is the most important export target region for Taiwan. As a result, it is of greater value to normalise the abnormal cross-strait economic ties than to make possible free trade with other countries or regions (Shanghai WTO Affairs Consultation Centre, 2011). If Taiwan signs a free trade agreement with the mainland, 
it is indubitable that in return, the mainland, as the locomotive of the global economy, will help Taiwan integrate itself into the global economic and trading system, as well as into the economic regionalisation of East Asia. Meanwhile, this will also help Taiwan better its macroeconomic atmosphere by signing such an agreement, creating conditions for Taiwan to recreate itself as a global innovation centre, a pivot of Asia-Pacific trade, and the headquarters of Taiwanese merchants and foreign merchants operating in that region (China Taiwan Organisation, 2010).

In September 2009, the economic authorities of Taiwan published the Assessment Report on the Effects of ECFA, which it had commissioned the Chung-hua Institution for Economic Research of Taiwan to prepare. According to the report, after signing ECFA, the economic growth rate of Taiwan would increase approximately by $1.65 \%$ to $1.72 \%$, providing 257,000 to 263,000 additional jobs, which would materially assist Taiwan in solving its unemployment problem. The report also stated that it would adduce positive effects for the chemical rubber, mechanical engineering, textile, steel and petroleum industries and coal product manufacturing in Taiwan by signing ECFA with the mainland (Caijing Network, 2009). Therefore, it is inevitable that Taiwan would chose to sign ECFA with the mainland. In fact, Taiwan had no option but to do it.

The mainland had also been upholding an open policy for Taiwan in the meanwhile. To illustrate, the preference treatment of the mainland for Taiwanese business people investing in the mainland is one of the examples of such an open and welcoming attitude. The mainland can not only utilise the capital, technology and management of Taiwanese business people to help upgrade its industries, but also enlarge the export of its products to Taiwan to secure the ongoing growth of its foreign trade. However, the economic concerns in this respect are only one part of the whole picture. In fact, Taiwan is the greatest beneficiary from the signing of ECFA. First, Taiwan's contribution to the economic growth of the mainland is limited. According to statistics, up until the end of December 2009, the mainland had approved an accumulative total of 80,061 programmes for Taiwanese investors, actually using 49.54 billion US dollars of Taiwanese investment, only $5.2 \%$ of the 
accumulative total of foreign investment in the mainland (Taiwan Affairs Office of the State Council PRC, 2010). Secondly, according to the "early harvest programme" of ECFA, the mainland benefits far less than Taiwan from it. Among the trading products that are to gradually reduce to a zero tariff within three years, 539 types of Taiwanese products will benefit, but only 267 types of mainland products will, one-half of those of Taiwan. In addition, the mainland has agreed with the listing by Taiwan to adjust downwards a total sum of 13.83 billion US dollars of the tariff on Taiwan; while Taiwan has agreed with the listing by the mainland to adjust downwards a total sum of 2.86 billion US dollars of the tariff on the mainland. Taiwan enjoys a tax exemption sum four times as large as the mainland does. Furthermore, the mainland offers to Taiwan policy measures more preferential than those under the WTO policies, while Taiwan offers an equal treatment with the measures under the WTO at the same level (Liu, 2010).

As is shown by these sources, the benefits of the mainland and Taiwan are very unbalanced. In some sense, they have not achieved "win-win". This explains why many Taiwanese hissed at signing ECFA, when the mainland advanced ECFA though the economic benefits on both side were highly unbalanced. The opposing Taiwanese questioned the hidden political intentions behind the "benefit donation theory", and worried that Taiwan could not afford the "political donation" that followed immediately (He, 2010).

Notwithstanding this circumstance, viewed in the long term, what ECFA means to the mainland shall lead to a completely different conclusion: after signing ECFA the Chinese mainland will identify with Taiwan regarding principles of trade thanks to the geographic and language advantages (Meng, Jiang \& Zhao, 2011). If the mainland and Taiwan can deepen their economic and trading cooperation within the framework of ECFA, both sides across the Taiwan Strait will definitely form a "mainland-Taiwan" economy; together with Hong Kong and Macau, they will form a "greater China economic sphere".

By reviewing the context in which China and the US joined APEC and by analyzing the reasons why the mainland and Taiwan signed ECFA, it is not difficult to 
discern that economic motivation is common in both cases. If people claim that the Chinese and American accession to APEC corresponds to trend of economic globalisation, the mainland and Taiwan signing ECFA conforms to the trend of economic regionalisation. Both the former and the latter are based on economic interests: free trade and better living. In fact, many scholars, for example Guo Jie (Guo, 2008) and Hua Min (Hua, Wang \& Zhou, 2002) believe that both trends lead to the same destination. Similar to Sino-US economic and trade ties under the APEC mechanism, cross-strait relations also have a solid base for cooperation under ECFA mechanism. Based on the common economic interests of the mainland and Taiwan, ECFA will create conditions for the unification of both economies across the Taiwan Strait at a higher level.

\subsection{ECFA will Promote Peace and Stability between the Mainland and Taiwan}

As shown by the history of international relations, it is not unusual for trade to become a force of peace. Only when two countries both recognise that the political and economic interests derived from trade are positive and need to be maintained by common efforts can trade become an effective motivation to prevent escalation of conflicts and promote sound development of political relations (Cai \& Chen, 2011). Apparently, for the mainland and Taiwan, ECFA is able to promote the healthy development of cross-strait relations. Compared with the purely economic motivations explaining why China and the US entered into APEC, the reality of cross-strait economic interests and mutual reliance proves that both the mainland and Taiwan urgently need ECFA. Both sides have manifested their sincere desire to maintain cross-strait economic exchanges under ECFA. As for the long-term cross-strait peace and stability, this demands not only a fundamental principle of seeking common ground while preserving differences based on economics, but also a mechanism whereby they resolve conflicts and increase trust. The institutional development for establishing a Cross-strait Economic Cooperation Committee per ECFA, shall provide institutional experience to establish cooperative mechanisms between the mainland and Taiwan in other respects. Next, with the Interdependence 
Theory and Neoliberalist theory, the author will expound the role of ECFA in cross-strait peace and stability.

\subsubsection{ECFA Promotes Cross-Strait Peace and Stability by Strengthening Mutual Economic Interdependence}

Both the economic liberalists Adam Smith (Smith, 2009), David Ricardo (Ricardo, 2011) and Karl Marx (Marx, 1975) deem that the daily economy is not a pure economy, but also a political phenomenon. Baron De Montesquieu asserts that peace is the natural result of trade (Montesquieu, 2009). When cross-strait relations need to be deepened, it is especially necessary for either side to use the "uniting" economic and trade ties to break the stalemate by showing its sincere desire for cooperation to the other side. Thus, when both sides are very cautious on political issues, regarding which even no major action is possible to be taken by either side, their cooperative economic and trade ties become an effective medium or agent that improves their political relations. In fact, ECFA not only is a result from the early-phase trade development and mutual economic reliance, but also is a policy that will safeguard the future unification of both economies, and further a mechanism that promotes peace and stability.

Economic and trade ties can generate unity that stabilises relations because cooperation and exchange in trade create great common interests for both parties. Trade is realistic and brings tangible, measurable and comparable absolute interests, and the desire of people to pursue interests is infinite and ceaseless. Development in trade not only produces more employment opportunities, but also enables consumers to enjoy cheap and good products and services, which maximising the value of consumer expenses. Moreover, businessmen and entrepreneurs are able to maximise their profits by pursuing the best allocation of resources when trading. All this will benefit the governance of the state. When all parties enjoy their own benefits from trade, this surely promotes internal political stability (Huang, 2008b). On the other hand, according to economics, the nature of capital is to expand. As long as no political red light obstructs it, trade will continue and expand (Marx, 1975). The 
groups and departments that enjoy vested interests from trade ties will no doubt try to urge the government to stabilise its policies so as to continue to benefit from such policies. Therefore, motivated by interests, the policies of peace and stability, similar with trade, also have the momentum to develop.

In fact, thanks to the efforts and close coordination of the relevant government agencies of both the mainland and Taiwan, ECFA has already manifested its initial success. According to statistics by the PRC General Administration of Customs, since the implementation of ECFA early harvest programme, the import and export of goods have been steadily increasing. Up until March 2011, the mainland has imported 684 million US dollars of goods produced in Taiwan, with tax cuts of 127 million RMB. With respect to the utility efficiency, in the first season of 2011 the mainland imported from Taiwan 333 eight-digit-tax-number items of products under ECFA, which involved all the ten categories of tax-cut products in ECFA early harvest programme of goods, or $59.8 \%$ of all the 557 ECFA preferential imported products (Lin \& He, 2011). In addition, contrary to the concerns of the opposing people, the circumstances did not happen where products from the mainland will pound the enterprises on the island if they are to enter Taiwan. Instead, ECFA early harvest programme benefits the small-and-medium-sized Taiwanese businesses; the original products of Taiwan also swiftly utilise this platform to export to the mainland, further opening their markets therein (Xinhua News, 2011). In summary, the positive effects of ECFA have far exceeded their prior concerns.

It is expected that as ECFA early harvest programme is further popularised and implemented, cross-strait trade will continue to rise. After ECFA attains its basic goals, and after a cross-strait free-trade zone is established as a reality, the economic unification of the mainland and Taiwan will enter a new phase. When cross-strait markets further open, enabling goods, services, capital, labour and other productive elements to flow freely, cross-strait economic unification will reach a new summit.

The third part of this chapter demonstrates that the successful signing of ECFA is based on rational reflection on respective economic interests. ECFA makes possible closer cross-strait relations and a lays more solid economic basis for cross-strait 
reconciliation and peace. Just as the Interdependence Theory holds, the core issue of contemporary international relations is a socio-economic issue. Thanks to the reciprocal trade and the expansion of the economic interdependence network among nations, they establish a bond of common interests to jointly enjoy the vested interests provided by peace. Therefore, the argument that ECFA will play the role of stabilising the cross-strait political relations in the future is in accord with the Interdependence Theory of the international political economy.

\subsubsection{ECFA Provides a Platform and Institutional Experience for Future Cross-strait Exchanges in Other Fields}

Neoliberalism emphasises that a system created by rational persons heavily influences the decision-making and actions of people in an interdependent society. It also asserts that a system can decrease transaction costs, facilitate information exchanges, reduce uncertainty and prevent fraud, thus rendering order and cooperation possible under anarchy (Su, 2000).

Examining cross-strait hostility and conflicts, we find that the ultimate cause is that the six-decade separate political rule has created a lack of mutual trust. This mistrust is largely because the mainland and Taiwan have had no regular contact mechanism. There was no mutually-acceptable principle to guide their exchanges; when a problem cropped up, they could not find a way to handle it appropriately. The problems might not have been interlinked, but viewed as a whole they were grievous. Few common interests and common experiences survived the long separation and confrontation across the Taiwan Strait. As a result, common memories and identification are absent between the people of the mainland and the people of Taiwan. However, without cultural identification there cannot be ethnic identification; without ethnic identification the basis for national identification cannot exist.

Viewed from the whole picture of cross-strait relations, signing ECFA not only regularised the disorderly forms of trade cooperation for three decades, but also created an accurate and rigorous system. The more far-reaching significance of signing ECFA is to develop cross-strait relations on a more proactive platform (Liu \& 
Bian, 2009). Through ECFA and economic cooperation, the mainland and Taiwan will not only further deepen their people-to-people exchanges, but also cultivate common memories of history, culture, economy and politics which will no doubt help heal the wounds of history (The Central People's Government of China News, 2011).

The cross-strait ECFA negotiations will help both sides ease the scepticism and fear of both, and boost the formation of mutual trust and collective identity. On the one hand, ECFA promotes trust by establishing a code of conduct, a supervisory mechanism and penalty measures. Within ECFA framework, the mainland and Taiwan established the Cross-Strait Economic Cooperation Committee, prescribed a series of principles and procedures with the core thrust of tariff deduction, for example, the Rules of Origin, the tariff discount or exemption mode, the customs procedures, and the dispute settlement body. No doubt this will provide a platform for both sides to expand their consensus and increase mutual trust, one which clarifies the future trend of cross-strait relations. On the other hand, through economic cooperation, ECFA cultivates a sense of common destiny across the Taiwan Strait, and facilitates the development of mutual trust and collective identity. Therefore, through facilitating cross-strait cultural exchanges, a common cultural identify may be forged, which in return may coalesce into a national identity. Only by doing this will a foundation be laid to further cross-strait peace and stability.

Though both sides now have reached the consensuses of "first easy things, then hard things", "first economy then politics", "seeking common ground while preserving differences" and "putting aside disputes", political discord still persists. As to how to institutionally realise the equal negotiation by both, this is a key issue pertinent to cross-strait peace and stability. In fact, the successful signing of ECFA is exactly a new phase or starting point in cross-strait relations entering institutional negotiations. It is of realistic value to sign a cross-strait political peace treaty, but compared with the trend of great exchange, great cooperation and great development of both sides thanks to their mutual economic reliance, it is not an issue that comes foremost or one that must be resolved first. Assuming that people across the Taiwan Strait can successfully lead this exchange, cooperation, development and blending in 
the next two decades, this will inevitably result in peace and stability across the Taiwan Strait. Therefore, in such a sense, the step itself, whereby the mainland and Taiwan utilise ECFA to deepen their cooperation and exchanges, is an example in itself of cross-strait stability and peace.

\section{Summary}

ECFA embodies significant content in the establishment of cross-strait institutional economic cooperation because ECFA determines the basic structure and development planning for future cross-strait relations. Though signing ECFA is of economic import in its fundamental character, ECFA itself is in reality a product of mutual political trust between the mainland and Taiwan. While accelerating economic interdependence, it benefits both sides with respect to accumulating mutual trust, promoting mutual political dialogue, and gradually thawing sensitive issues. Therefore, as the media has observed, ECFA is a historic economic cooperation agreement that transcends its economic aspect. Its regularisation of economic and trade ties symbolises the closest era that the mainland and Taiwan have entered into after six decades of separation. It creates a proactive atmosphere for cross-strait peace and stability ( $\mathrm{Li}, 2010 \mathrm{~b})$.

To view ECFA from the standpoint of an economic policy, economic concern requires both the mainland and Taiwan to formulate their own policy based on the principle of upholding their own interests. However the economic principle of mutual reciprocity and mutual benefit requires both the mainland and Taiwan not only to protect their own interests, but also try to take care of the interest of the other side. In order to develop a prosperous cross-strait economy, both the mainland and Taiwan have to strengthen cross-strait dialogue and coordination. Therefore, in the wave of economic globalisation, economic cooperation as one of the most important issues in cross-strait relations will promote the relationship between mainland China and Taiwan towards interdependence and cooperation, definitely not confrontation and containment. 


\section{Chapter 5 Role of Taiwanese Business People: An Important Element for Cross-strait Peace and Stability}

\section{Introduction}

Taiwanese business people ${ }^{5}$ are not only the main instruments of cross-strait economic activities and trade, but also are messengers of cross-strait communications. Taiwan business people play a significant role of reducing misunderstanding and increasing mutual trust between mainland China and Taiwan. Therefore, a review of the roles of Taiwan business people in cross-strait social, cultural and political exchanges is of crucial importance for readers to understand the future trend of cross-strait relations.

In this chapter, the author first presents an introduction to the history and current state of investment by Taiwanese business people on the mainland so as to afford the reader a thorough understanding of them. Thereafter, the author will illustrate with relevant data the contributions of Taiwanese business people to the economic development of both the mainland and Taiwan, and their important role in institutionalizing cross-strait trade. Also, an attempt is made to prove the fact that it is investment by Taiwanese business people on the mainland that is increasingly deepening the cultural and social exchanges between both sides across the Taiwan Strait. Finally, the author demonstrates the significance of Taiwanese business people in cross-strait peace and stability by describing their close relations with both governments across the Taiwan Strait.

\subsection{History and Current State of Investment by Taiwanese Business People on the Mainland}

\footnotetext{
5 At Present, the definition of Taiwan Business People is still missing. This thesis adopts Li Fei's definition which refers to Taiwan Business People as "the investors from the island of Taiwan, overseas Taiwan Enterprises or organizations came to invest on the mainland during the 1980s" (Li, 2004, p.393).
} 
Due to the unique historical background of cross-strait economic development, both Taiwan and the mainland have combined their political consideration with their economic concerns, a circumstance which gives rise to the complexity of interlaced economic interests and political controversies in trade interactions between mainland China and Taiwan. According to research conducted by Shi Zulin and Huang Tao (Shi \& Huang, 2007), political elements notably affect cross-strait economic and trade relations. The authors' findings also correspond with their opinion following an investigation into the relevant data (see Figure 5) on investment by Taiwanese business people on the mainland from 1989 to 2010. Therefore, a review of the economic and trade policies of both sides and an investigation into the development of Taiwanese investment on the mainland serves as an indispensable aid in charting the progress of investment by Taiwanese business people on the mainland.

Figure 5 Taiwan Business People's Mainland Investment from 1989 to $2010^{6}$

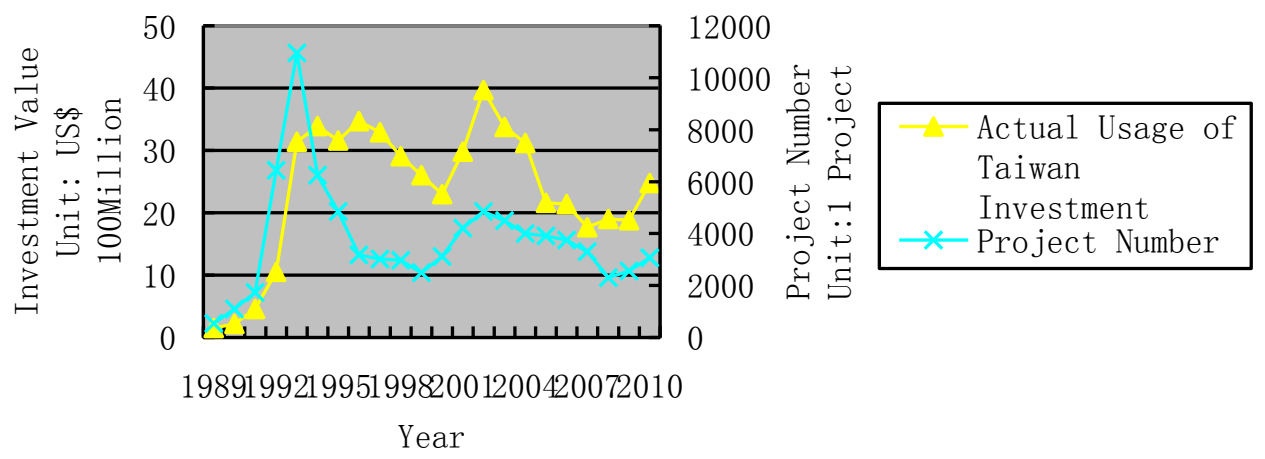

After viewing relevant academic books in this field (Yu, 1999; Wang, 2000; Yan, 2011; Lv, Cheng, \& Zou, 2008), and based on the periodicity as demonstrated by the time sequence in Figure 5, the author categorizes investment by Taiwanese business

\footnotetext{
${ }^{6}$ 1989-1999 Data Source: Yan An. "Studies on Taiwan Business People's Investment on the Mainland from the Political and Economic Perspective" (Yan, 2011). 2000-2010 Data Source: Taiwan Affairs Council of the State Council PRC. "Taiwan Business People's Mainland Investment from 2000 to 2008”. Taiwan Affairs Office of the State Council PRC Website. Accessed in November 2011, http://www.gwytb.gov.cn/lajm/lajm/201101/t20110121 1718252.htm.
} 
people on the mainland into the following five phases:

\subsubsection{9-1986: An Exploring Phase}

In 1979, the Standing Committee of the National People's Congress ("SCNPC") issued the Message to Taiwan Compatriots, which "voiced an invitation for the opposite side of the Taiwan Strait to commence cross-strait trade and conduct cross-strait economic, trade and cultural exchanges" (Wang, 1999a, p.5). In April 1983, the State Council of the PRC promulgated the Measures of Special Preferences for Taiwanese Compatriots to Invest in the Special Economic Zones to encourage Taiwanese business people to invest on the mainland. However, because the Taiwan authorities implemented the "Three Nos" policy (no contact, no compromise, and no negotiations with the mainland) and forbade civil exchanges, the gross volume and number of projects of Taiwanese investment on the mainland were extremely limited during that period. Where investment existed, it was surreptitious and fragmentary. For example, in January 1981 the first Taiwanese-invested enterprises appeared in Shenzhen and Quanzhou, without exception in the form of such Sino-foreign investment vehicles as Hong Kong Investment or joint ventures in an effort to avert punishment by the Taiwan authorities (Wang, 2000).

\subsubsection{7-1993: A Fast Growing Phase}

In 1987 Taiwan declared the suspension of martial law and controls over foreign visits. Taiwan also officially allowed people to visit their relatives on the mainland. Many Taiwanese business people availed themselves of that occasion to examine business opportunities on the mainland. After 1988, considering their own interests, the Taiwan authorities shifted their stance towards Taiwan business people's mainland investment from proscription to acquiescence, and issued the Temporary Regulation on the Relations among People across the Taiwan Strait. With conditions, the Taiwan authorities allowed Taiwanese business people to invest indirectly on the mainland. On the other hand, the mainland also timely provided favourable conditions for Taiwanese business people. The Provisions of the State Council on Encouraging 
Investment by Compatriots from Taiwan was promulgated on July 61988 to protect the lawful rights and interests of Taiwanese investors. In addition, investment zones for Taiwanese business people were approved for establishment in Haicang and Maiwei of Fujian Province on February 1, 1989. During the period from 1987 to 1993, encouraged by the Taiwan authorities' loosening policies towards Taiwan business people's mainland investment, the enthusiasm of Taiwanese business people to invest on the mainland gradually rose to a high level.

In 1992, after Deng Xiaoping delivered his famous speeches affirming the reform and opening-up policy during his famous inspection tour of South China and the establishment of a socialist market economy, Taiwan business people initiated a new wave of massive investment on the mainland. The "Wang-Koo talks" inspired a mania among medium-and-large-sized Taiwanese enterprises - including listed companies - to send business exploration teams to the mainland. The trend of more large enterprises or groups investing on the mainland became apparent (Yan, 2011). According to statistics, 1992 was the year in which Taiwanese investment in the mainland grew at the fastest rate. Throughout 1992, Taiwanese business people invested in 6,430 projects on the mainland having a gross volume of 5.54 billion US dollars. Compared with the 1991 data, Taiwan business people's mainland investment increased by 2.7 times and 3 times respectively (China External Economic Statistical Yearbook Editorial Committee, 1993, p.68). This unprecedented growth in Taiwan business people's mainland investment reached its apex in 1993.

\subsubsection{4-2000: A Slowdown Phase}

In 1996 the Taiwan authorities implemented the "Go South Policy", attempting to cool down the heat of investment in the mainland. However, the real trend was that the mainland was still the focus of Taiwan's outbound investment. As a result, the Taiwan authorities asserted that it was necessary to shape its policy towards the mainland as "patient instead of hasty and far-sighted to ensure stability". The Taiwan

\footnotetext{
${ }^{7}$ Go South Policy refers to the Taiwan authorities' policy of guiding Taiwanese business people to invest in Southeast Asia instead of mainland China.
} 
authorities believed Taiwan business people must consider cross-strait political risks when doing business with the mainland (Yu, 1999). In April 1997, the Taiwan Legislative Yuan passed the Draft Regulation on the Relations among the People of the Taiwan Region and the Mainland Region, primarily to limit Taiwanese business people's mainland investment. Therefore, the growth rate of projects by Taiwan business people approved by the Taiwan authorities during this phase was essentially negative.

Although cross-strait relations were undergoing a period of freeze, Taiwanese business people's willingness to invest in the mainland did not flag. According to statistics in 1996, more than $60 \%$ of people from the Taiwan business and commercial community expressed pessimism about the political stability and social order of the island of Taiwan. More than 54\% of Taiwan business people were dissatisfied with the investment environment in Taiwan. In sharp contrast, $77 \%$ of Taiwan business people were optimistic about the investment environment on the mainland (Zhao, 1996). During the period from 1994 to 2000, the mainland's efforts to actively serve Taiwan business people and protect their rights and interests contributed much to Taiwan business people's enthusiasm to invest in the mainland. In 1994 the mainland promulgated the Law on the Protection of the Investment of Taiwan Compatriots, creating for them an open environment of development in accordance with law and fair competition, while rendering their operating rights and interests more secure. Thus, though the investment scales dropped year after year during the period from 1994 to 2000, the virtual investment volume did not dramatically change, staying at 3 billion US dollars each year except for 2000 (See Figure 5).

\subsubsection{1-2005: A Second Growing Phase}

The policy "patient instead of hasty, and far-sighted to ensure stability" implemented by the Taiwan authorities proved of poor effect for two reasons. Firstly, it failed to stop the heated wave of Taiwanese investment in the mainland. Secondly, this policy forced many Taiwan enterprises to go underground with respect to investing in the mainland, e.g. Taiwanese enterprises resorted to the circumvention of first investing 
capital in Hong Kong, Macau or other locations, and then transferring the capital from such third land to the mainland. Taiwan business people's indirect mainland investment was hard for the Taiwan authorities to control. In the mean time, Taiwan's economic growth drastically dropped due to the Taiwan administration's shift and the uncertain policies of the new government. Many Taiwanese enterprises moved out of the island of Taiwan seeking greater business opportunities (CCTV News, 2002). Because the Taiwanese administration substituted the "proactively open and efficiently administered" policy for the "patient instead of hasty, and far-sighted to ensure stability" policy (People's News, 2002a), Taiwan had to open up those programmes where had previously been restricted and reopen cross-strait trade and investment.

On the other hand, the mainland government insisted on the attitude of "not affecting or interfering in cross-strait economic cooperation with political disagreements" (China Taiwan Organization, 2004) so as to actively protect the rights and interests of Taiwanese business people on the mainland. As a result, the volume and number of programmes forming the object of Taiwanese investment powerfully resurged after years of ebbing and began to rise again. According to the statistics of a relevant Taiwanese government agency, the volume of investment by Taiwanese business people in mainland China rose from 2.784 billion US dollars in 2001 to 6.007 billion US dollars in 2005. Since 2002, the percentage of Taiwan business people's mainland investment was more than $50 \%$ of Taiwan's gross outbound investment in other countries or regions. In $2005,71.07 \%$ of total Taiwan outbound investment went to mainland China (Zhang, 2007a, p.39).

\subsubsection{5-Present: A Fully Developing Phase}

From April 26, 2005 to May 3,2005 Hu Jintao, Lian Zhan and Song Chuyu held the historic meeting, proposing "to establish cross-strait economic cooperation mechanisms" (People's News, 2005). On December 5, 2008, both sides signed the cross-strait Postal Agreement, cross-strait Sea Transport Agreement and cross-strait Air Transport Agreement, basically materializing cross-strait postal, sea and air links. 
In addition, the mainland issued the Circular on the Administrative Measures for Investment of Mainland Enterprises in the Taiwan Region, confirming at the central government level the relevant measures for mainland capital to enter Taiwan. In June 2009, the Taiwan authorities promulgated the Measures on the Investment by People of the Mainland Region in Taiwan, the Measures for Approving For-Profit Entities of the Mainland Region to Establish Branch Companies or Offices in Taiwan, thus officially opening the door for mainland enterprise to invest in Taiwan and to establish branch companies there. The opening up of mainland enterprises' Taiwan investment marked the advent of the era of mutual direct investment between mainland China and Taiwan. The replacement of one-sided investment provided new opportunities for both business people from the two sides. Currently, there are more than one million Taiwanese business people living on the mainland. 54\% of Taiwanese outbound investment targets the mainland, and more than 90 of the 100 largest Taiwanese enterprises have invested in the mainland (Zhou, 2008).

According to relevant data published by the mainland government, from 1991 to 2010, the number of programmes which Taiwanese business people invested on the mainland grew from 1,735 to 3,072. In the decades from 1990 to 2010, the Taiwanese capital that the mainland virtually utilized accumulated to 51.544 billion US dollars, among which 2.48 billion US dollars ${ }^{8}$ were virtually utilized in 2010. The mainland market became a primary target region for Taiwanese capital, and the proportion of such investment in the gross foreign investment of Taiwan has since been rising (See Table 1).

\footnotetext{
${ }^{8}$ This Number is calculated and based on the data released by Ministry of Commerce PRC and Taiwan Affairs Office of the State Council PRC.
} 
Table 1 Taiwan's Total Overseas Direct Investment \& Taiwan's Mainland Investment from 1981 to $2003^{9} \quad$ Unit: US\$ 100 Million

\begin{tabular}{|l|l|l|l|}
\hline Year & $\begin{array}{l}\text { Total Investment } \\
\text { Value }\end{array}$ & To the Mainland & $\begin{array}{l}\text { Mainland's Proportion of } \\
\text { Taiwan's Total Overseas } \\
\text { Investment }\end{array}$ \\
\hline $1981-1990$ & $\sim 40$ & $\sim 7$ & $\sim 20$ \\
\hline 1991 & 18.30 & 1.74 & 9.52 \\
\hline 1992 & 11.34 & 2.47 & 21.78 \\
\hline 1993 & 48.29 & 31.68 & 65.61 \\
\hline 1994 & 25.79 & 9.62 & 37.31 \\
\hline 1995 & 24.50 & 10.93 & 44.61 \\
\hline 1996 & 33.95 & 12.29 & 36.21 \\
\hline 1997 & 72.28 & 43.34 & 59.96 \\
\hline 1998 & 53.31 & 20.35 & 38.17 \\
\hline 1999 & 45.22 & 12.53 & 27.71 \\
\hline 2000 & 76.84 & 26.07 & 33.93 \\
\hline 2001 & 71.76 & 27.84 & 38.80 \\
\hline 2002 & 100.93 & 67.23 & 66.61 \\
\hline 2003 & 116.67 & 76.99 & 65.99 \\
\hline $1991-2003$ & 699.18 & 343.09 & 49.07 \\
\hline
\end{tabular}

According to the latest data, until the end of 2009, the Taiwan authorities have ratified an accumulative gross volume of 82 billion US dollars of Taiwanese investment in the mainland, almost $60 \%$ of Taiwan's gross foreign investment in these years (Xie, 2010). Meanwhile Taiwan remains an important source region from which the mainland absorbs external investment (See Figure 6).

\footnotetext{
9 Data Source: Li Long Sheng. “A Research about the Impacts of Taiwan's Business People's Direct Investment to the Mainland on Taiwan's Economy from 1991 to 2003” (Li, 2005).
} 
Figure 6 Ranking of Taiwan's Investment on Total Mainland's Overseas Investment from 1990 to $2008^{10}$

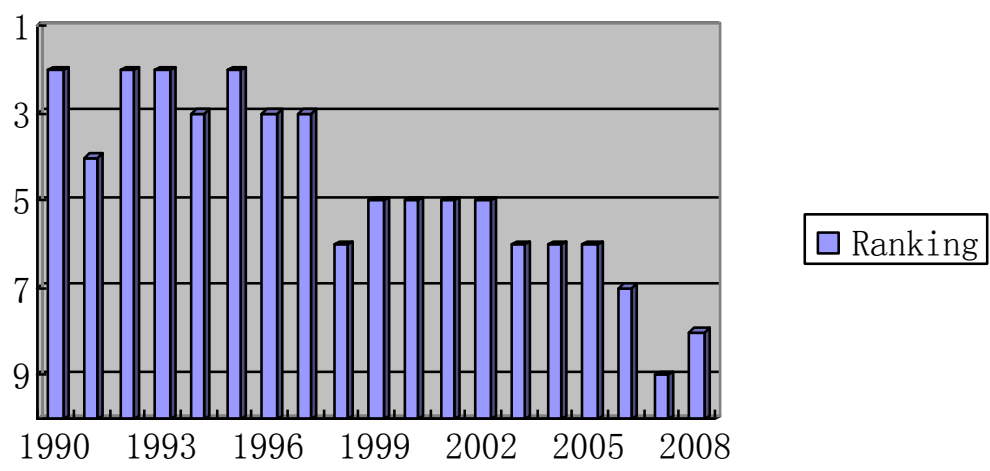

After more than twenty years' development, the industries which Taiwanese business people invested on the mainland have expanded from the processing industries and labour-intensive industries to include capital-intensive industries and technology-intensive industries $(\mathrm{Su}, 2011)$, in particular, the electronics industry characterized by advanced technology and high added-value, and the financial industry and the insurance industry that wield such significant economic clout. According to statistics, from 1991 to 2004 the proportion of investment by Taiwanese business people in the electronics and electric products manufacturing industries accounted for $34.1 \%$ of the gross volume of Taiwanese investment on the mainland (Shi \& Huang, 2007, p.139). In short, the investment by Taiwanese business people in the mainland has shown a trend towards diversification. Moreover, Taiwanese business people' investment in the mainland has spread to encompass the entire country, in addition to creating intensive Taiwanese investment zones in the Pearl River Delta, the Yangze River Delta and in Fujian Province. Taiwan business people's mainland investment expansion has also penetrated as far as the Bohai Bay, and China's Northeast, Middle and Western regions (See Figure 7).

\footnotetext{
${ }^{10}$ Data Source: Yan An. "Studies on Taiwan Business People's Investment in the Mainland from the Political and Economic Perspective" (Yan, 2011).
} 
Figure 7 Main Areas of Taiwan Business People's Mainland Investment from 1991 to July $2009^{11}$
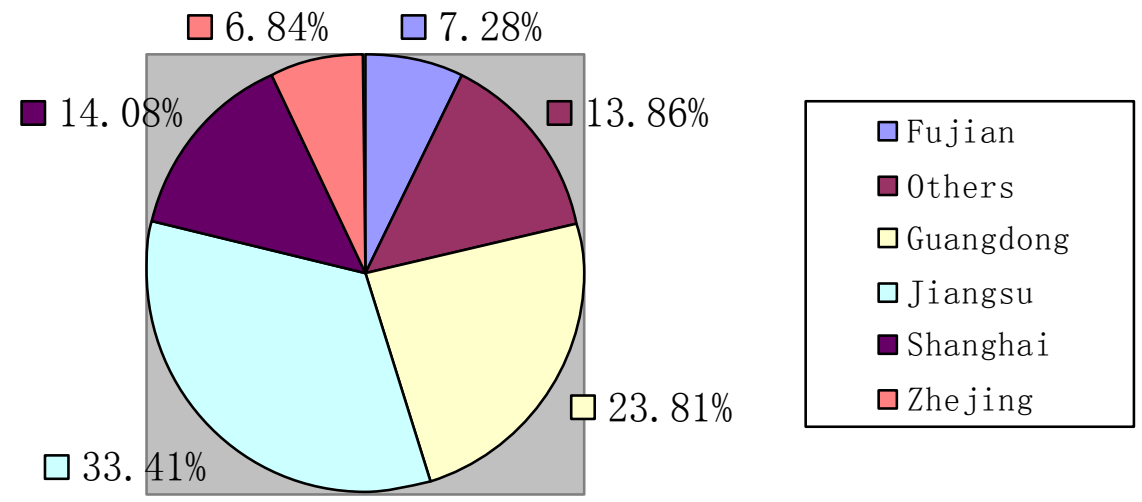

The three decades of investment by Taiwanese business people in the mainland comes as a natural result of economic globalization and regionalization, as directed by the market and not subject to artificial human restrictions. The accumulation in these many years has not only generated the giant volume of cross-strait trade and investment by Taiwanese business people in the mainland, also led to the being of a group directly interests closely knitted accordingly - Taiwanese business people, who have become an increasingly important new force influencing the direction of cross-strait relations.

\subsection{The Influence of Taiwanese Business People on the Economies of Both}

\section{Taiwan and the Mainland}

The nearly three decades of investment by Taiwanese business people has not only

\footnotetext{
${ }^{11}$ Data Source: Taiwan Office of the State Council PRC. "Main Areas and Industries of Taiwan's Mainland Investment". Taiwan Affairs Office of the State Council PRC Website. Accessed in December 2011, http://www.gwytb.gov.cn/tztw/twjmgk/201101/t20110118 1699300.htm.
} 
revitalized both economies, but also promoted the institutional development of cross-strait economic and trade cooperation. Facts demonstrate that, via their investment, Taiwanese business people significantly contributed to creation of a win-win situation for both the mainland and Taiwan.

\subsubsection{Promoting Economic Development across the Taiwan Strait}

Taiwan is an island economy, and one which relies to a considerable extent on foreign trade for its economic growth. Reference is made in Chapter 4 to the fact that the mainland is the greatest source of trade surplus for Taiwan. The giant surplus has not only complemented the years of its trade deficit with Japan, but also contributed greatly to its 370 billion US dollars of foreign exchange reserves (QQ News, 2010). Continuing expansion of Taiwanese exports to the mainland, and Taiwan's huge trade surplus have become major forces driving Taiwan's economic growth. Statistics indicate that $75 \%$ of Taiwan's exports to the mainland occur in enterprises which are also active investors in mainland China (Su, 2011). Therefore, Taiwanese business people's enterprises may be characterized as the pillars of Taiwan's economy. Taiwanese scholars also assert that the investment by Taiwanese business people in the mainland helps promote the growth of Taiwan's economy, and create more employment opportunities (Li, 2005b).

In addition, the continuous expansion of investment by Taiwanese business people in the mainland has energetically facilitated the upgrading of Taiwan's industrial structures. Taiwan business people have primarily invested in manufacturing industries on the mainland. Among the products that Taiwan exports to the mainland, the overwhelming majority fall under the categories of materials for manufacturing and intermediate products or components (See Figure 8). In particular, the proportion of electronic information and mechanical products and their components has witnessed a rapidly escalating trend year after year. 
Figure 8 Main Industries of Taiwan Business People's Mainland Investment from 1991 to July $2009^{12}$
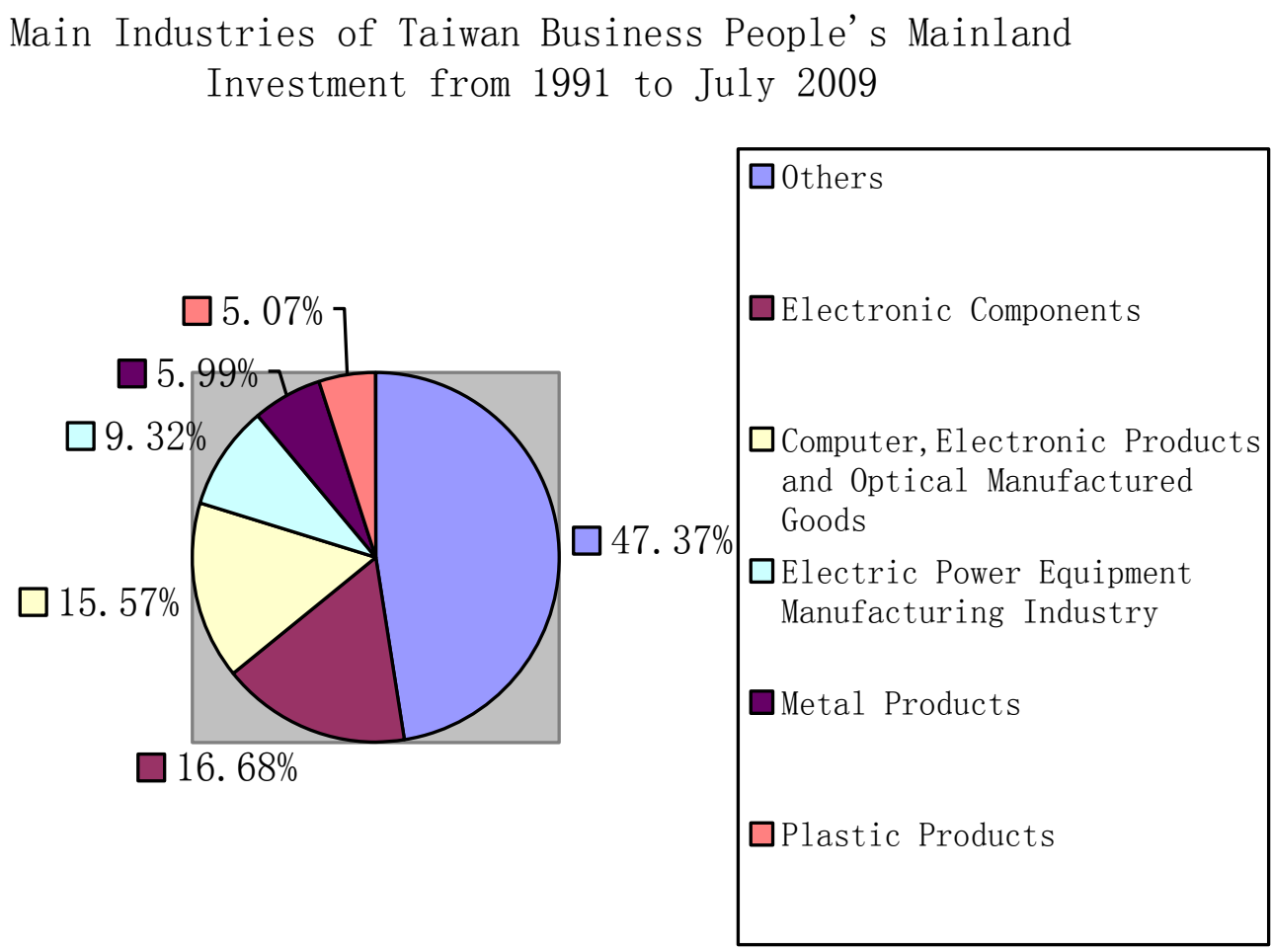

Therefore, as a result of moving the labour-intensive industries from Taiwan to the mainland, on the one hand, Taiwanese business people have had more capital to develop capital intensive and technology intensive industries, creating favourable conditions for the upgrading of industrial structure of the Taiwan region. This has aided Taiwanese enterprises in shifting from original equipment manufacturing to establishing their own brands, and from pursuing cost minimization development models to enterprise value maximization models. On the other hand, some middle-stream and upper-stream enterprises have produced and exported materials and components of high added-value and high technology to supply the middle-stream and lower-stream enterprises on the mainland. The middle and upper-stream Taiwan enterprises and the middle and lower-stream mainland enterprises have formed an internal mode of division of labour within industries. This 
model can be described as Taiwanese enterprises exporting intermediate products or components for fabrication, produced and sold on the mainland or sold to a third country or region $(\mathrm{Su}, 2011)$. The establishment of the global operating mode has significantly enhanced Taiwan enterprises' international competitive power.

In addition, approximately one million Taiwanese business people invest, do business or work on the mainland have made remarkable contributions to the economic development, employment and technologic upgrading of the mainland (Zhu, 2004). On April 29, 2005, Hu Jintao, General Secretary of the CCP, in his historic meeting with Lian Zhan, Chairman of the KMT, stated that "the construction achievements made by the mainland also include the important contributions made by Taiwanese compatriots" (Xinhua News, 2005). This is an objective and positive comment from the CCP on the role of Taiwanese business people.

The contributions of Taiwanese business people on the mainland occur primarily in the following areas:

Firstly, absorbing foreign investment assumes great weight in the strategy of China's reform and opening. Taiwanese business people are important external investors in mainland economic development. Figure 6 has already demonstrated Taiwanese business people's key position as China's foreign investors, and thus a repetition thereof is unnecessary here.

Secondly, Taiwan business people's massive mainland investment helps create employment opportunities on the mainland. The unemployment problem was grave after the mainland adopted a market economy and reformed its state-owned enterprises. Taiwan-funded enterprises on the mainland are primarily labour-intensive ones that can provide many jobs in those locations where Taiwanese investment occurs. According to statistics, the 70,000 already operating Taiwan-funded enterprises employ approximately 10 million mainland people. On average, each Taiwan-funded enterprise employs about 140 mainland workers. If one adds those working on infrastructure construction for Taiwanese enterprises and those providing 
services to Taiwan business people, the job opportunities provided by Taiwan-funded enterprises range approximately from 20 million to 30 million (Yan, 2011). As a result, Taiwan business people's massive mainland investment has made significant contributions to the mainland by easing its unemployment pressure.

Thirdly, Taiwan business people's mainland investment provides enterprise managerial experience and relatively advanced production technologies. Modern enterprises cannot develop without advanced enterprise cultures. Scholar Li Fei has remarked on the active role of Taiwan business people as follows, "the clever investment creed, mature market views, advanced managerial experience and developed operating models of Taiwanese enterprises directly influence local managerial personnel, technological workers and ordinary workers employed by Taiwan-funded enterprises, but also provide a mode of development from which lessons may be drawn. Thus investment by Taiwan business people in the mainland fosters a sound economic competition environment that facilitates changes in the conditions of the local market economy" (Li, 2005a, p.294). Therefore, Taiwan-funded enterprises are subjects that mainland enterprises can research and learn from. Taiwan-funded enterprises help mainland entrepreneurs broaden their horizons, and expand the scope for mainland enterprise to link up with the practices of the outside world.

\subsubsection{Promoting Institutional Development of Cross-strait Economic and Trade Cooperation}

Affected by political elements, a formal institutional framework, co-established, mutually-respected and effectively implemented has always been absent from cross-strait economic and trade cooperation since before the thaw in the relationship between mainland China and Taiwan. Such cooperation developed swiftly because of civil forces, especially Taiwanese business people investing in the mainland. Based on blood ties, friendship and hometown ties, business people on both sides across the Taiwan Strait have conducted economic and trade exchanges subject to an informal and uncertain set of rules in a manner where virtually "all is conducted in silence" 
(Liu, 2011, p.68).

However, trade and investment conflicts, open commodity programmes, opening schedules and the extent of the opening of any bilateral or multilateral economic ties must be resolved via consultation through formal mechanisms (Huaxia News, 2009). Consequently, the increasingly active trade spurred both governments to mutually adjust their policies so as to facilitate the establishment and development of cross-strait economic cooperation models, consultation channels and relevant operating rules.

In November 1992, the SEF and the ARATS reached the "1992 Consensus", for the first time opening the path of institutionalization of cross-strait consultation, which secretly negotiated the institutionalization of cross-strait economic cooperation (Liu, 2011). Afterwards, affected by Taiwan independence activities, cross-strait relations deteriorated and institutional negotiations were once even dropped. However the continuous increase of interdependence of the mainland and Taiwan economies has triggered strong opposition from Taiwanese business people to the mainland policy of the Taiwanese authorities which caused deterioration in cross-strait relations and conflicts in the Taiwan Strait. The Taiwanese authorities were compelled to open up previously restricted economic programmes. Therefore, although the basis for institutional cooperation was mired in stalemate, progress was not completely absent. In April 2005, Hu Jintao, General Secretary of the CCP, and Lian Zhan, Chairman of the KMT, reached the mutual vision of cross-strait peaceful development. As mentioned above, these two cross-strait leaders first proposed that both Parties should jointly promote all-out exchanges and create cross-strait economic cooperation mechanisms. Top meetings between $\mathrm{Hu}$ and Lian thus marked the beginning of cross-strait institutional trade cooperation.

After that, irrespective of whether it was in the "Cross-strait Civil Elite Forum" held in Shanghai in September 2005 (Jia, 2005), or in the "Cross-strait Economic and Trade Forum" which was successfully held on repeated occasions (Zhao, 2009), cross-strait economic cooperative mechanisms were among the core subjects. In June 
2008, following the recommencement of the negotiation mechanism among the SEF and the ARATS, the success of the five-time "meetings of Jiang Bingkun and Chen Yunlin" ushered in a new phase in theoretical research into and virtual construction of cross-strait economic cooperative mechanisms (Niu, 2009).

The signing of ECFA was a remarkable achievement during this period, and the most glorious page in the history of Taiwanese business people's promotion of the institutional development of cross-strait economic and trade development. Industrial circles in Taiwan were even more eager when compared to the already active attitude adopted by the KMT in signing ECFA. Because, for the Taiwanese enterprises located on the mainland which heavily relied on the import of half-finished products from Taiwan, if the mainland did not reduce its tariffs, Taiwanese enterprises on the mainland certainly would have had to purchase from other regions. That would not only have weakened the links between the mainland and Taiwan, but also affected the capability of Taiwanese enterprises to expand on the mainland (Lin, 2009).

Nevertheless, distressed by the unique political environment of Taiwan, the schedule of negotiating ECFA had not been agreed upon, and the KMT and the DPP debated what to name the agreement. Thus, many Taiwanese people called out loudly in favour of ECFA. Some Taiwanese business people and Taiwanese industrial and business groups even paid their own money to publish many advertisements in Taiwanese media, stating directly that ECFA was of vital importance to Taiwan. In February 2009, six major industrial and business groups, including the Taiwan General Association of Business, jointly published a declaration, advising the Taiwanese authorities to sign the economic cooperation agreement with the mainland as soon as possible, and arguing the advisability of Taiwan first having a "reduction of cross-strait tariffs on key products" with the mainland (Sun, 2010). Starting from March 2009, Taiwanese business people in Dongguan, Guangdong province, delivered speeches in many Taiwanese universities and associations, urging the signing of ECFA (Zhou, 2010). Powerfully championed by Taiwanese business people, the negotiation schedule for ECFA was agreed upon near the end of 2009, and ECFA 
was successfully signed in June, 2010.

The strong demand of Taiwanese business people to invest in the mainland was reflected in ECFA. As stated in Chapter 4, ECFA lists the promotion of investment cooperation as an important object, including establishing an investment protection mechanism, increasing transparency in investment-related regulations, gradually reducing restrictions on mutual investment between the two parties, and promoting facilitation of investment. These measures may assist Taiwanese business people in eliminating the obstacles to investment, shortening the time of application and reducing elements of uncertainty.

\subsection{The Role of Taiwanese Business People in Cross-Strait Social and Cultural Exchanges and Blending}

Since the introduction of familial visits by the Taiwan authorities, the goal of Taiwanese visiting the mainland is primarily to visit relatives, travel as tourists and visit friends. As cross-strait economic ties become increasingly close, that wave of people is gradually being replaced by Taiwanese business people who frequently travel across the Taiwan Strait for business and trade. According to statistics published by the mainland, as early as 2001 , the number of business travellers to the mainland far exceeded that of the family visitors and tourists, thus becoming the mainstream of travellers from Taiwan to the mainland (Sina News, 2001). According to research conducted by two scholars (Zhang \& Li, 2005), Taiwanese business people's investment in the mainland has influenced the tendency for Taiwanese to visit the mainland and for mainland residents to visit Taiwan. Research reveals that Taiwanese mainland investment increases by every 100 million US dollars whenever an additional 48,572 Taiwanese visit the mainland, while another 2,312 mainland residents visit Taiwan. This in turn demonstrates that such investment significantly promotes cross-strait exchanges of personnel. Thus, cultivated by investment by Taiwanese business people on the mainland, starting from zero, cross-strait personnel 
exchanges have undergone a process of rapid increase (See Figure 9 and Figure 10).

Figure 9 Cross-strait Personal Exchange from 1987 to $2010^{13}$

Cross-strait Personal Exchange Unit: 1 Time

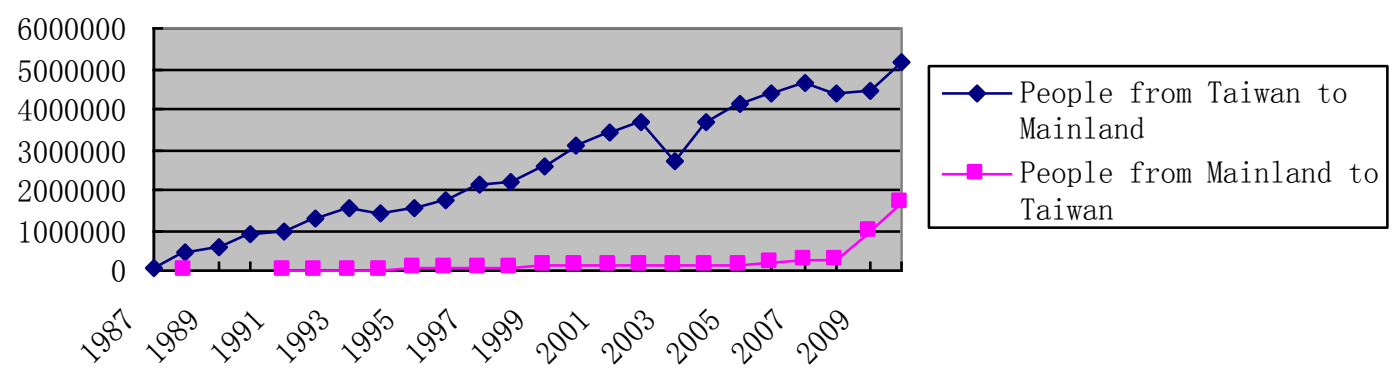

Figure 10 Cross-strait Communication from 1987 to $2010^{14}$

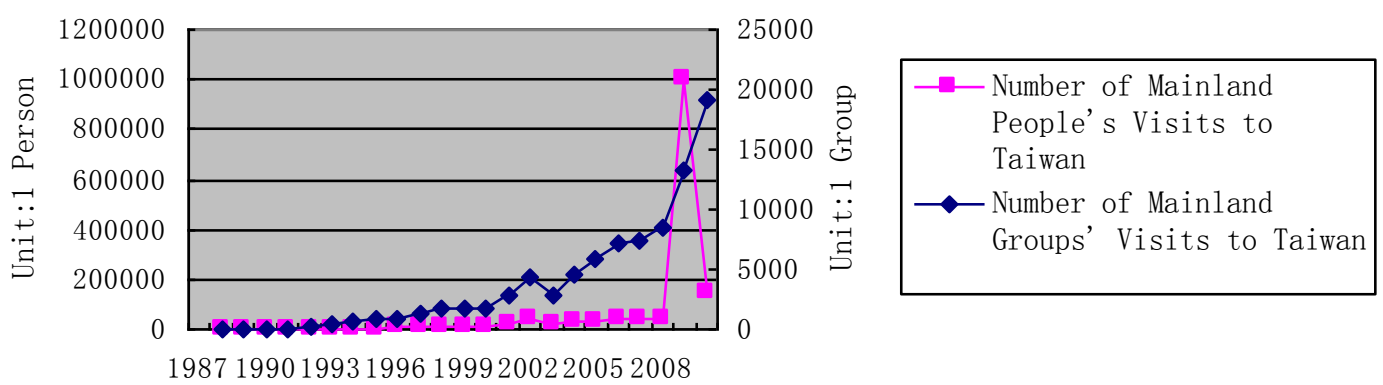

Furthermore, as cross-strait exchanges among people have become more intensive, especially as Taiwanese business people joined these exchange, cross-strait marriages have also gradually increased. According to statistics by the Ministry of Civil Affairs of the PRC, since the recommencement of cross-strait civilian exchanges in 1987, more than 300,000 couples from across the Taiwan Strait have married (Wei,

\footnotetext{
${ }^{13}$ Data Source: Taiwan Affairs Office of the State Council PRC. "Statistics about Cross-strait Personal Exchange and Communication". Taiwan Affairs Office of the State Council PRC Website. Accessed in December 2011b, http://www.gwytb.gov.cn/lajlwl/rywltj/201101/t20110120_1715616.htm.

14 Ibid.
} 
2010). According to statistics by the relevant government agency of Taiwan, the number of mainland spouses applying to visit Taiwan had reached to 250,000 persons as of January 2008 (Beijing Morning Post, 2008). In addition, as more Taiwanese business people visit the mainland and more cross-strait marriages take place, the problem of their children's education becomes more and more pronounced. To avoid dividing families, and in response to appeals by Taiwanese business people, the mainland has established schools for the children of Taiwanese business people in Guangdong, Shanghai and other places in an effort to localize the education of these children (Sohu News, 2005).

In addition, Taiwanese business people investing in and/or doing business on the mainland also contribute greatly to the promotion of cross-strait cultural and social exchanges. For instance, by using their special identities, some Taiwanese business people actively organise mutual exchanges among civilian cultural groups in Hong Kong, Macau and Taiwan to publicly introduce the real conditions of the Hong Kong and Macau societies, politics, economies, cultures, legal systems, democracies and living standards, following the reunification of Hong Kong and Macau with the mainland (Shi, 2002).

It may be clearly seen from the above data and analysis that investment by Taiwanese business people in the mainland has greatly enhanced cross-strait civil integration, which has already developed from the purely economic to the social level. This means that structural changes have replaced quantitative increases in cross-strait exchanges and integration in the last two decades. As cross-strait economic interdependence increases and investment by Taiwanese business people in the mainland grows, it can be expected that such exchanges shall expand in all respects and integration in many fields shall reach a new peak.

\subsection{The Close Relations among Taiwanese Business People with Both Governments across the Taiwan Strait}


The previous two chapters note that in the context of economic globalization and regionalization, relations between nations become closer due to the increasing expansion of global trade. To some extent, international relations have already progressed into a state of interdependence. Therefore, nations place increasing emphasis on their economic relations with others; and economic security is becoming increasingly important among the issues of international politics. It may be asserted that economic elements have profoundly changed international relations.

Economic globalization and regionalization primarily rely on the motivation by the numerous trans-national corporations active in the global market. Trans-national corporations' international operations have brought about the interdependence of economies, which on the one hand has created economic reciprocity among nations, and on the other has increased their mutual economic sensitivity. Furthermore, the increase in the number of trans-national corporations has blurred the distinction between international and internal politics, directly bringing international political and economic interactions into the domestic sphere and thus forming the interdependent political and economic relations of nations wherein these both enjoy the benefits of and limit one another (Li, Luo \& Zhao, 2002). According to Interdependence Theory, non-state acting entities already have enough economic might and global power to influence other acting entities (Song \& Chen, 2001). Obviously, trans-national corporations are such non-state acting entities. With their huge size and powerful economic might, while closely linking the global economy, trans-national corporation shave also closely linked the global politics. Political decisions of a nation, whether internal or external, shall have effects on the nerves of global politics. Therefore, the renowned scholar Robert Gilpin characterizes this era as "an era of the trans-national corporations" (Robert Gilpin, 2001, p.161).

According to the authoritative definition by the United Nations Conference on Trade and Development, a trans-national corporation means one enterprise that owns production facilities in at least two countries. According to the 1996 Investment Report of the World Bank, the parent company of a trans-national corporation means 
"an enterprise that has a fixed amount of equity capital and controls assets owned by foreign economic entities" (Chen, 1999, p.2). From the above definitions, readers can see that the essential nature of a trans-national corporation is to directly invest in foreign countries. Thus, for the mainland and Taiwan, Taiwanese business people directly investing in the mainland are now playing the role of "trans-national corporations" even though Taiwan is not formally recognised as an independent country in the world.

Capital always flow into a safe country because security is the basic prerequisite for enterprises to generate profits and benefits, so once invested in a country, capital will try to shape a political environment in favour of its interests. For the security of their capital and the smooth running of their production and operations, trans-national corporations usually submit to administration by the government of the host country, lobby and influence the policies of that government according to their own interests in order to try their best to forestall political risks between the host country and their home country (Grieco \& Ikenberry, 2008). Therefore, a kind of complicated relation exists among trans-national corporations, their home countries and host countries. On the one hand, trans-national corporations are influenced by their home countries and host countries, making them passive instruments of policy. On the other hand, trans-national corporations fully initiate moves to influence both their home and host countries and their bilateral relations through the trans-national corporations' own economic activities (Huang, 2008a). For Taiwanese business people that cross the Taiwan Strait this is no exception. Taiwan business people must always deal with the complicated relations subsisting between the mainland government and the Taiwanese political parties. Taiwan business people not only demand that the mainland provide protection, aid, and various preferences and conveniences for their development, but also try to induce the Taiwan authorities to change their policies and actions to alleviate cross-strait relations, and even adopt methods that run counter to the Taiwan authorities in order to win profits.

\subsubsection{Taiwanese Business People and the Mainland Government}


The mainland government has always had a proactively open and warmly welcoming attitude towards investment by Taiwanese business people. This is mainly because of the changes in the mainland's domestic development strategy and the mainland's desire for final reunification between the two sides.

After the "Cultural Revolution" ended on the mainland in the latter 1970s, it urgently needed to re-establish and enhance the basis for the people's recognition of its political authority through economic growth and the raising of living standards. Therefore, the mainland gradually established its development strategy that has economic construction as its core and adheres to reform and opening-up. Because of this strategy, economic interests replaced political interests to a considerable degree as the target of pleas by mainland enterprises and individuals. Economic efficiency also made itself to a remarkable extent the standard by which to assay the achievements of different levels of the mainland government, and thus also resulted in significant changes in the political functions of the mainland government.

At that time, faced with the problems of seriously lacking domestic capital, poor technology and want of relevant materials, the mainland was experiencing difficulty in developing its economy, and needed large amounts of external investment and foreign trade. With Taiwan lying in very close geographical proximity to China, Taiwanese business people not only had abundant capital, advanced technology and managerial methods, but also strong investment intent stemming from the emotional bonds of a common nation with a common history. Thus, the mainland's welcoming Taiwanese business people to invest was a reasonable choice.

On the other hand, Taiwan's economic surge was completed during the period when Taiwan and the mainland were isolated. As living standards in Taiwan improved, Taiwanese increasingly identified with the Republic of China (Taiwan), while their identification with the mainland rested merely on historical and cultural links, real interests being absent. Therefore, to terminate cross-strait isolation and to achieve economic integration across the Taiwan Strait, the mainland has a strong demand for investment by Taiwanese business people. The mainland hopes that Taiwan business 
people's mainland investment fosters cross-strait trade, and creates common interests and destiny for the people of Taiwan and the mainland, so that the Taiwanese people's identification with the mainland may increase.

Summing up the mainland's consideration of Taiwan business people's mainland investment, scholar Yan An has concluded that for the mainland, the investment by Taiwanese business people not only serves the mainland's economic construction, but also thaws the man-made situation of separation and brings cross-strait peace and stability. This may be characterized as win-win (Yan, 2006). Accordingly, consistently attracting more, better and larger Taiwanese enterprises to invest in and build factories on the mainland so as to help assimilate them as mainland enterprises is the primary and consistent content of the mainland's policies towards Taiwanese business people. The ensuing several paragraphs will study Taiwan business people's special relationship with the mainland government from Taiwan's motivation to invest in the mainland.

After the mainland adopted measures to attract Taiwanese business people, the Taiwanese enterprises became subject to intense competitive pressure from the rest of the region and the world as European and American countries gradually shifted the focus of their foreign trade and investment to the Asia-Pacific region. Taiwanese business people generally realized that if they did not actively establish the mainland market as their hinterland for economic development, it would prove difficult for Taiwan to maintain its competitive advantages in economic globalization and regionalization.

Their level of internationalization is an important factor that maintains and improves the competitive capabilities of enterprises. Thus for Taiwanese enterprises, especially larger ones, investing in the mainland represents not only an attempt at internationalization, but also serves as an important guarantee for Taiwanese enterprises to expand their sizes in order to form into world-class trans-national corporations. According to the results of research by Taiwanese scholar Li Yang, the higher the Taiwanese enterprises' export proportions are, the more willing are the 
small-and-medium sized Taiwanese enterprises to directly invest in foreign lands; also, making use of low-cost labour forces and following their primary customers are the primary motivations to invest outside Taiwan ( $\mathrm{Li}, 2003)$. The mainland happened to satisfy these conditions for investment for three reasons. First, the mainland's policy of economic reform and opening-up provides Taiwan business people with the opportunity to investigate the mainland before the investment occurs. Second, the mainland boasts an abundant supply of labour, with comparatively low wages and production costs. Third, mainland China has a huge market potential which suits Taiwanese business people's preferences for investment (CCTV News, 2003).

Therefore, although the Taiwan authorities imposed many restrictions on their nationals' investment in the mainland, its low production costs, huge market potential, cheap labour, stable political environment and preferential investment policies exerted a noteworthy magnetic effect attracting Taiwanese business people's mainland investment. Data further indicates that the selection to invest made by these business people was correct. According to statistics, the proportion of profitable Taiwanese enterprises on the mainland has always been more than $60 \%$, and that of those primarily concentrating on investing and engaging in industrial production programmes ran as high as in excess of $70 \%$ ( $\mathrm{Li}, 2008)$. In sum, in order to facilitate industrial upgrading and economic internationalization, and to obtain more interests in competition, Taiwanese business people actively exploited their special relationship with the mainland and their preferential treatment to expand their investment and continue to promote cross-strait economic cooperation.

In addition, according to research by scholars, although there are different backgrounds to political parties and political preferences among Taiwanese business people currently investing on the mainland, and the proportion of Pan-Blue supporters is generally a bit higher than that of Pan-Green supporters, in virtual business activities the political preferences of Taiwanese business people are not very marked. Taiwan business people's positions of a specific political party are not obvious either (Chen, 2005). Peng Weixue, Director of the General Office, from the Institute of 
Taiwan Studies, the Chinese Academy of Social Sciences, once summarized the political attitude of Taiwanese business people as politically cold and economically hot, and asserted that most Taiwanese business people are very practical and unwilling to publicly express their political attitudes (Sun \& Chen, 2005).

This low-profile political attitude prevalent among Taiwanese business people casts into prominence the essential characteristics of business professionals, who in general primarily focus on survival and profit, and who most urgently need favourable policies for their businesses. Mr. Zhang Hanwen, former President of the Dongguan Association of Taiwanese business people publicly stated that these are all middle voters, who usually care little about Taiwan's politics and have no particular political claims. Taiwan business people are concerned however with whether the Taiwanese political leaders can maintain cross-strait peace and stability and whether they genuinely seek to maximize the benefits of the people of Taiwan (Liu, Zhang \& Cheng, 2004). Taiwan business people investing in the mainland clearly realize that if tension continues in cross-strait relations their economic interests will be directly injured.

Therefore, although few Taiwanese business people press or express their political positions on specific political issues to the Taiwan authorities, most hope that decision-makers in both Taiwan and the mainland can maintain peace and stability across the Taiwan Strait. Also, Taiwan business people hope to expand cross-strait economic and trade exchanges between the two sides. For instance, although Taiwanese business people seldom discuss cross-strait political issues, renowned entrepreneurs like WANG Yongqing, ZHANG Rongfa and XU Wenlong have all expressed their hope that the Taiwan authorities realize cross-strait postal, sea and air communications. It was in response to years of calls and urgings by Taiwanese business people that the Taiwan authorities had to modify the Regulation on the Relations among the People of the Taiwan Region and the Mainland Region, and laid down the schedule for direct cross-strait flights (Sun, 2008).

The above analysis indicates that, even though Taiwanese business people do not 
favour immediate reunification, they hope cross-strait relations maintain their current status quo and peacefulness, so that Taiwan business people can invest and develop in a relatively safe and stable political environment. This basically corresponds with the objectives of the mainland, which are to seek economic integration and political reunification. Therefore, the numerous Taiwanese business people investing in the mainland are important forces keeping cross-strait relations developing peacefully and stably. As the Taiwanese scholar CHEN Jianzhong asserts, the Taiwanese groups are the lubricating oil of cross-strait relations, and even the golden key for Taiwan to open the political and economic cage of the mainland (Chen, 2004).

In sum, the above several paragraphs relate that economic interests alone are the greatest impulsion for Taiwan business people to invest in the mainland. However, economic and political factors are the main considerations of the mainland government on investment by Taiwanese Business People.

\subsubsection{Taiwanese Business People and Taiwan's Political Parties}

Compared with the agreement between Taiwanese business people and the mainland government in their political and economic objectives, the demands of Taiwanese business people have always been at odds with the requirements of the Taiwanese authorities prior to 2008. First, the political objective of the Taiwan authorities was to pursue autonomy to the greatest degree possible. Consequently, the Taiwan authorities manifested an oppositional attitude towards the mainland government, which conflicted with the peace and stability sought by Taiwanese business people. Second, the Taiwan authorities' political objective has always resulted in corresponding economic policies. For instance, the Taiwan authorities' economic policies such as the "Go South Policy", the policy of "patient instead of hasty" and Taiwan authorities' actions such as the refusal of the "postal, sea and air communications", stifling mainland capital and restricting Taiwanese business people' investment runs counter to the market mechanism. The Taiwanese authorities before Ma Ying-jeou assumed the presidency in 2008 were in evident conflict with the wishes of Taiwanese business people to actively open cross-strait trade. 
Therefore, Taiwanese business people investing in the mainland were not what the Taiwan authorities fostered, rather what the Taiwan authorities disliked as illustrated in above in this chapter. In the view of the Taiwan authorities that opposed investment by Taiwanese business people in the mainland, these business people were characterised as "enemies and traitors who empty Taiwan, create black holes in Taiwan's industries, hit the local industries and aid the mainland with their economic power" (Liu \& Gao, 2004).

Nevertheless, factual evidence demonstrates the irresistible nature of economic rules. The measures above taken by the Taiwan authorities not only failed to remove the mainland element in Taiwan business people's economic activities, but also raised the extent of cross-strait economic interdependence due to the circumventing tactics adopted by Taiwanese business people. Taiwan business people went a step ahead these policies, forcing the Taiwanese authorities to gradually loosen certain restrictions and recognise the lawfulness of their actions on the mainland. Consequently, the economic policies of Taiwan towards the mainland fell into passive, negative and defensive positions.

According to Miao, when the objectives of trans-national corporations disagree with the foreign policies of their home country, the government change the actions of the firms by administrative means, or the firms lobby the government to amend its foreign policies (Miao, 2003). Even though administrative enforcement by the Taiwan authorities largely failed to block Taiwanese business people's investment in the mainland, Taiwan business people nevertheless sought to influence Taiwanese government policies by such means as voting.

Taiwan business people gradually realized that, in a global market where cruel and fierce competition prevails, as micro subjects in the market, they need the aid of government power to clear the obstacles to the internationalization of capital, free trade and integration of production while they obey the law of value. Without government support, it is impossible for trans-national corporations to win victories in global competition. Furthermore, the progress of Taiwan's democracy provided 
favourable conditions for Taiwanese business people to intervene in political procedures and influence government policies. As a result, to safeguard their investment interests on the mainland, Taiwanese business people have altered their low-profile political attitude since 2004, and tried to make their impact on Taiwan's politics. For instance, during the 2004 presidential election in Taiwan, Taiwanese business people in Shanghai and other places initiated the "Love Hometown Programme" to call upon Taiwanese business people to go back to Taiwan and vote (Sina News, 2004).

With the size of their population, industries, talent pools and capital, Taiwanese business people matter to Taiwan's politics. Their impact on Taiwanese election of political parties is most notable. This is attributable to the following two causes. On the one hand, the number of Taiwanese business people groups has been increasing day by day. According to statistics, more than one million Taiwanese business people have invested in the mainland. These enterprises hire as many as several tens of thousands Taiwanese business elites. Also thousands of Taiwanese students study on the mainland. Although the proportion of Taiwanese living on the mainland is not large relative to Taiwan's overall population, their capability to wield an influence cannot be overrated if the number of their relatives and friends is factored into determining their influence (Sun \& Chen, 2005). On the other hand, political forces in Taiwan are currently quite balanced, and the margin of votes is very small, so every vote matters to both the Pan-Blue and Pan-Green parties. Therefore, Taiwanese business people who have one million votes are a key minority that influences general elections. Taiwan business people are considered one of the most important "trump cards to victory" for political parties in Taiwan, even as the "twenty-sixth county that decides the future result of Taiwan's presidential election" (Liu, Zhang \& Cheng, 2004, p.1).

As their political position continues to grow, Taiwanese business people have become subjects that all Taiwanese political parties try to attract and please. The time Taiwan business people attracted most attention was in helping the KMT regain 
power in the 2008 Taiwan presidential election.

After it gained power, the DPP made few achievements in economic development and political construction, continued undermining cross-strait relations, and repeatedly obstructed cross-strait postal, sea and air communications. The above acts by the DPP resulted in political turbulences within Taiwan and induced deterioration of cross-strait relations, while worsening Taiwan's investment environment. In consequence, Taiwanese industrial and commercial circles were utterly disappointed by these actions of the DPP, and one after another called for the Taiwanese authorities to adopt more pragmatic policies on cross-strait relations (Sina News, 2006). That was why in 2008 when the KMT candidate Ma Ying-jeou declared that after he won the election he would loosen the restraints on Taiwanese business people' investment in the mainland, Taiwanese business people were suffused with hope for a re-accession to power by the KMT. According to media reports, when Taiwan business people attended the "Mainland Taiwanese Business people Talk", they directly expressed to Ma Ying-jeou that, "The only method to help Taiwanese business people is for the KMT to definitely regain power in 2008" (People's Daily, 2007, p.3). In the 2008 Taiwan presidential election, almost 250,000 Taiwanese business people went home to vote. Taiwan business people's desire to vote rose to an unprecedented level. Compared with the 150,000 persons voting in 2004 (Zhong \& $\mathrm{Xu}, 2008, \mathrm{p} .25)$, it chalked up an increase of almost 1.7 times.

On Ma Ying-jeou's victory in 2008, Professor YANG Kaihuang of the Mingchuan University of Taiwan explained that the Ma Ying-jeou administration's opinions on cross-strait relations were mutual economic opening, political reconciliation within Taiwan, mutual respect between Taiwan and the mainland, and the facilitation of peace. These opinions differed very much from Taiwan's policies in the last eight years of the DPP's imposed self-isolation, which provoked the mainland and engendered instability by exploiting public worries. The KMT's new cross-strait policies provided an opportunity for Taiwan to return to equilibrium, to revitalize itself, and to embrace globalization after passionate political struggles (Lin, Yang, Lin 
\& $\mathrm{Li}, 2008)$. The victory of the KMT in 2008 was thus not merely a victory of the Kuomintang, but rather a victory of the people of Taiwan, especially Taiwanese business people. After regaining power, the KMT adopted a pragmatic approach to actively increase mutual trust and consensus with the mainland. That made possible a normal and healthy environment for Taiwanese business people to invest in the mainland, so that Taiwan business people could concentrate on running business, instead of being sidetracked by political and ideological issues.

To recap the above analysis, motivated by the investment by Taiwanese business people in the mainland, the Taiwan authorities changed their policies towards the mainland from forbidding to acquiescing in, and from loosening to regularizing, towards the direction of being open and legal. It is not difficult to imagine that, without the investment by Taiwanese business people on the mainland, peace and stability between the mainland and Taiwan could not have been possible.

It is undeniable that it is the increasing cross-strait economic interdependence and the promotion of Taiwanese business people behind the policies that make possible the continual advancement of cross-strait relations. Even when the forces for Taiwan Independence were wreaking their worst, the mainland maintained the highest degree of rationality. In the words of SU Qi, the former director of the Mainland Affairs Council of Taiwan, the current cross-strait political trend is "to unite the non-political elements and surround the political elements" (Sun \& Chen, 2005).

\section{Summary}

A scholar commented that "[E]ven if economic integration does not make political agreements superfluous, it lays the foundation for political agreements" (Wang, 1999b, p.415). Thus, though cross-strait economic cooperation and recognition does not directly create political reunification; maintaining the long-term stable and close economic exchanges is tantamount to maintaining the stable communication and close exchanges between the mainland and Taiwan which establish a solid edifice for peace and stability across the Taiwan Strait (Shan, 2009). This point can be illustrated by the 
fact that Taiwanese business people' investment in the mainland facilitates cross-strait social, cultural and political exchanges and integration. It is safe to assert that the economic activities of Taiwanese business people' investing in the mainland not only lays a solid material foundation to the integration state of "I in you and you in me", but also improves the mutual recognition of the people across the Taiwan Strait, as well as shaping an active and harmonious environment for cross-strait political exchanges. Therefore, Taiwanese business people are an important element for cross-strait peace and stability. 


\section{Chapter 6 Mainland China's New Policy towards Taiwan}

\section{Introduction}

Whether in terms of their aggregate economies ${ }^{15}$ or respective military strength ${ }^{16}$, there can be no doubt whatsoever that mainland China enjoys an overwhelming advantage over Taiwan in the cross-strait situation. Accordingly, understanding the mainland's policy towards Taiwan and analyzing its effects form the focal points of this research on the relationship between mainland China and Taiwan.

On New Year's Day 1979, the Standing Committee of the National People's Congress issued the Message to Taiwan Compatriots, thereby enshrining the peaceful development of cross-strait relations at the core of its reunification policy. During the 30 year interval since its issue, in the first decade, the two sides broke free from their state of long-term isolation and established economic, trade and cultural exchanges; in the second decade, the "Wang-Koo talks" were held and the two sides reached the 1992 Consensus. This laid the political foundation for cross-strait exchanges. In the third decade, the two sides activated negotiations geared toward achieving the "Three Direct Links" and inaugurated direct talks between the CCP and the KMT, - the first since the final rift gaped open between Mao Zedong and Chiang Kai-shek 50-odd years before. These developments have significantly improved cross-strait relations

(Li, 2009, p.82). Therefore, the Message to Taiwan Compatriots has performed a

\footnotetext{
15 As announced by the PRC Bureau of Statistics, the mainland's 2010 GDP was 39.7983 trillion RMB, about 6.04 trillion US dollars. Taiwan reported its GDP in 2010 as 136144.15 trillion NTD, which according to Taiwan's official exchange rate, was 430.451 billion US dollars in total.

Mainland Data Source: National Bureau of Statistics China. "Report on the Social and Economic Achievements during the $11^{\text {th }}$ Five Year Plan". National Bureau of Statistics China Website. Accessed January 2012, http://www.stats.gov.cn/was40/gitji detail.jsp?searchword=\%B9\%FA\%C4\%DA\%C9\%FA\%B2\%FA\%D7\%DC\%D $\underline{6 \% B 5 \& \text { channelid }=6697 \& \text { record }=65}$.

Taiwan Data Source: China Economic and Social Development Database. "Social and Economic Indicators with oRespect t Taiwan". China Economic and Social Development Website. Accessed January 2012, http://tongji.cnki.net/kns55/navi/result.aspx?id=N2011060008\&file=N2011060008000254\&floor=1.

16 In May 2006, Chinese Military Strength Report published by the US Department of Defence concedes that "cross-strait military strength was gradually tilting towards Beijing", and "had caused regional unbalance". The report of the Defence Research Institute of Japan also avers that the cross-strait "military strength comparison is becoming more and more favourable to mainland China". The analysis and forecast of the Ministry of National Defence of Taiwan even deemed that, between 2010 and 2012 "the military strength of CPC would have an absolute advantage in all respects (Fan, 2008, p.54).
} 
key historical function in the peaceful development of cross-strait relations. It not only marks a significant adjustment and transformation of mainland China's policy towards Taiwan - thus creating the necessary prerequisite and safe environment for terminating cross-strait military confrontation and realizing cross-strait communications - but also later became the mainland's basic guiding principle and policy towards Taiwan. China's peaceful reunification thereby became the leitmotif and mantra of the mainland's policy towards resolving the Taiwan issue.

$\mathrm{Hu}$ Jintao's speech at the conversazione held in commemoration of the $30^{\text {th }}$ anniversary of the issue of the Message to Taiwan Compatriots at the end of 2008 encapsulated a summary of the CCP's policy towards Taiwan over the previous 30 years. Hu's speech not only brought up a series of new discussions and proposals for promoting peaceful development across the Taiwan Strait, but also represented an innovation in the mainland's Taiwan policy during the period of peaceful development of cross-strait relations. Therefore, Hu's speech was regarded as embodying the mainland's latest policy towards Taiwan (Yan, 2009). This chapter will analyze the trend in cross-strait relations by interpreting Hu Jintao's new policy towards Taiwan.

\subsection{The Core of Hu Jintao's Speech: Mainland's Implementing "Peaceful Development" Policy towards Taiwan}

$\mathrm{Hu}$ Jintao expresses the idea that in order to develop cross-strait relations, mainland Chinese must firmly grasp the theme of peaceful development across the Taiwan Strait. Hu Jintao said "We must adhere to the principle that mainland and Taiwan belong to one China as the political foundation upon which to promote peaceful development across the Taiwan Strait. We must set deepening communication and cooperation, as well as promoting consultation and negotiation, as important approaches to advance peaceful development across the Taiwan Strait. We must also posit encouraging cross-strait compatriots to struggle in unity as the powerful driving force for promoting cross-strait peaceful development"(Hu, 2009, p.6). Only if both sides make progress together, pull together and work hard as a team, can the mainland and Taiwan open up a new prospect for the peaceful development of cross-strait 
relations.

In addition to comprehensively expounding the ideal of peaceful development of cross-strait relations, $\mathrm{Hu}$ offered six recommendations targeting that end. Hu's six proposals are as follows, "to adhere to the One China Principle and enhance political mutual trust; to boost economic cooperation and promote common development; to carry forward Chinese culture and strengthen spiritual bonds; to enhance personal exchanges and expand communications among all walks of life; to maintain the sovereignty of the state and consult on foreign affairs; to end the hostile confrontation and reach an agreement for peace" (Hu, 2009, p.6-7).

\subsection{Interpreting Mainland's "Peaceful Development" Policy towards Taiwan}

In general, on the one hand the "peaceful development" policy reflects the continuity of the mainland's policy towards Taiwan, in accordance with the peaceful reunification principle established in the Message to Taiwan Compatriots. On the other hand, this policy realistically confronts the cross-strait status quo, and has thus achieved breakthroughs in many respects. The mainland's peaceful development policy towards Taiwan seems more pragmatic, more flexible and more self-confident. According to statistics, in Hu Jintao's 5067 word speech, he mentions "development" 61 times, "peace" 52 times and "peaceful development" 29 times in total. $\mathrm{Hu}$, as the president of the PRC, his high frequency of mentioning "peaceful development" to some extent demonstrates the mainland's goodwill to Taiwan and the mainland's sincere attitude towards cross-strait peaceful development. Consequently, some mainland scholars hold that the focus of the CCP's work on Taiwan has shifted from "fighting against independence and promoting reunification" to "fighting against independence, promoting peace, and achieving gradual reunification" (China News, 2008).

\subsubsection{The Target of the Mainland's "Peaceful Development" Policy towards Taiwan: Realizing Cross-Strait Peaceful Reunification}

The renowned Chinese scholar Fei Xiaotong in the book Jiangcun Economy, as also 
his doctoral dissertation of London University in 1938, stated that China was unable to bear any more wastage of wealth and energy caused by mistakes. While, in order to avert errors, Fei explicitly noted that Chinese people must arrive at correct interpretations or analyses of the situations or conditions; otherwise, even though China harbours the best of intentions and the most ideal of objectives, plans were bound to miscarry if premised upon initial false understandings and perspectives with regard to the changing environment (Fei, 2001).

With the continuous amalgamation and development of the global economy, the interdependency among all countries has increased greatly, producing a situation in which a slight move in one part may affect the entire tableau. Cooperation and confrontation between countries is thus becoming more complex. As Neoliberalist theory and Interdependent theory hold, countries of the world will make great exertions to explore cooperation and communication with one another, avoid the "Zero-Sum Phenomenon" occasioned by conflicts, and pursue "win-win" peaceful development. Furthermore, pursuing global cooperation has also become a common goal in the international community, while peace and development have become the theme of the times.

After the great upheaval of "the Cultural Revolution" ended in 1979, the mainland shifted its national strategic emphasis to economic construction, and it began to implement reform and opening-up policies, while also continuing its adherence to the policy of employing peaceful means to resolve the Taiwan issue. The mainland's choice came not only as a result of the urgent need for a stable international environment as a necessary predicate for domestic economic construction, but it also complied with the cross-strait populace's expectations for peace and development. More importantly, pursuing peaceful means to solve the Taiwan issue was a positive response to the new international situation. The achievements realised during China's 30 years of reform and opening in the economic, social and other fields, as well as the notable improvement of cross-strait relations, have also effectively validated mainland China's policy of peace.

Although the current possibility of a deterioration in the relationship or even the 
outbreak of war between the mainland and Taiwan is low, the historical review of cross-strait relations in Chapter Two herein demonstrates that, if not handled properly, some setbacks and reversals might again arise respecting the Taiwan issue as had been the case in the past few decades across the Taiwan Strait. The choice between peace and war is the ultimate and most extreme choice for both the mainland and Taiwan. If war broke out between the two sides, the mainland might forfeit a stable environment within which to advance its economic construction, and Taiwan might have to face threats to its security or even survival. Therefore, considering the cost relation between risks and benefits, such a bipolar choice, black or white, leaving no room for manoeuvre, is neither reasonable nor economical for either side, given their high degree of economic interdependency. As Interdependency Theory emphasises, for a country with high interdependency or extensive opening-up, the inducement to provoke war or conflicts that might damage economic associations is low in these countries or regions because of the huge opportunity and adjustment costs (Rosecrance, 1986). As demonstrated above, both the mainland and Taiwan need a stable environment for their economic development, especially the mainland. Peaceful reunification remains the key mantra of the mainland's policy towards Taiwan.

The Taiwan issue traces its roots to the Chinese Civil War. According to $\mathrm{Lu}$ Xinjian and Fan Qianfeng, the mainland's standpoint is that the Taiwan issue is an exclusive matter of China's internal affairs. In interpreting the term "China", in fact, both the mainland and Taiwan concedes that they are legally an indivisible part of China. From this point of view, the mainland and Taiwan never legally split (Lu \& Fan, 2010, p.79). Therefore, mainland scholar Zhang Nianchi deems that since there is no disunion, there can be no unification, that any supposed "reunification" now is a mere reconciliation of the two sides (Yu, Cheng, Wang, Huang \& Zhang, 2010, p.10).

Such scholars' opinions happen to coincide with the message expressed by the mainland's policy of "Peaceful Development". The essence of "Peaceful Development" policy is transferring the mainland's Taiwan strategy from the model of the central government imposing reunification on the local Taiwan authority to the model of working together to promote reunification on the basis of equality, 
reconciliation and cooperation between the two sides. Obviously, the mainland's authority has become entrenched, having transited intact through the past sixty years of political hostility and social separation, a political scheme or a peace agreement is no longer the optimum method to definitively resolve the Taiwan issue once and for all. A lack of common interest and experience is a very important cause of the previous cross-strait estrangement and governmental separation. Consequently, resolving the Taiwan issue presents more a problem of reconstructing national identification and rebuilding ethnic identification. The reconstruction of national identification across the Taiwan Strait requires both sides to develop a sense of a common heritage, and to enhance mutual trust, as well as a collective identity forged via means of cross-strait collaborative development. In sum, though peaceful reunification is undoubtedly the target both sides across the Taiwan Strait pursue, the process is far more important than the result. In other words, people should transform the pursuit for reunification into a process of cross-strait mutual development.

As mentioned in Chapter Four herein, when discussing ECFA's significance in establishing institutional consultation mechanisms for both sides, the practical significance of the two sides' signing the "Confrontation Termination Treaty" or "Cross-Strait Peace Treaty" exists. However, the need to sign such treaties is no longer the task of highest priority when contrasted against the current cross-strait momentum of great communication, great cooperation and great development. The mainland has repeatedly stressed the importance of both sides enhancing common economic interests and cultivating a common memory of history, culture, economy and politics (The Central People's Government of China News, 2011), which clearly demonstrates the mainland's wish to provide platforms and opportunities for mutual amalgamation and reconstruction of identification through cross-strait peaceful development. It is a logical inference that, if the CCP can successfully play a leading role in such communication, cooperation, development and amalgamation between the mainland and Taiwan in future decades, cross-strait relations might undergo a qualitative transformation and many concerns that people now confront might be readily solved. 


\subsubsection{The Political Basis for the Peaceful Development of Cross-Strait Relations: the One China Principle}

The One China Principle is the baseline of the mainland's policy towards Taiwan, and it has never changed. The newest explanation of the connotation of the One China Principle is:

"There is only one China in the world. China's sovereignty and territorial integrity tolerate no division. Since 1949, though the reunification of the mainland and Taiwan has not been achieved, this situation is by no means tantamount to a partitioning of China's territory and sovereignty. The past six decades' separation is a mere political confrontation which is a relic inherited from the Chinese Civil War in the middle and latter 1940s of the previous century. The long separation across the Taiwan Strait does not change the fact that both the mainland and Taiwan belong to one Greater China" (Hu, 2009, p.7).

In contrast to the expression of the previous One China Principle, which is that "there is only one China, Taiwan is an inalienable part of Chinese territory, and the government of the PRC is the only legal government of China" (The Central People's Government of China News, 2005), in its current formulation, the One China Principle appears more flexible and inclusive since it explicitly characterises the cross-strait issue as being one of governmental authority, rather than one of sovereignty. Thus it reinvigorates the stagnancy of cross-strait relations after the publishing of Lee Teng-hui's Two States Theory and lays the foundations for restarting cross-strait relations. The new expression further sets the mainland and Taiwan on an equal footing, accords equal status and treatment to Taiwan, and is thus much more readily comprehensible by and acceptable to the Taiwanese.

With regard to these expansions of the connotations of the One China policy, $\mathrm{Hu}$ Jintao further avers: "If the two sides can reach a common cognition and a consensual viewpoint concerning the implementation of the One China principle, we will hold the cornerstone to construct an edifice of political mutual trust between the mainland and Taiwan. Thus, everything would be subject to discussion." (Hu, 2009, p.6). 
Consequently, after the CCP manifested a conciliatory and positive posture towards Taiwan, it is logical to understand why cross-strait relations could have so quickly and significantly improved after the Ma Ying-jeou administration conceded the "1992 Consensus" and announced its adherence to the One China Principle.

Notwithstanding the above, however, the political divergence between the two sides remains evident. Although Ma Ying-jeou advocates the "1992 Consensus" which incorporates the One China Principle, yet the One China to which Ma's administration pledges its adherence to refers to the ROC. From Ma's government's point of view, the ROC lies solely within the island of Taiwan, and thus excludes the mainland (Chen, 2008). This standpoint has altered the original Kuomintang reunification strategy, to that the ROC should include both Taiwan and the mainland. The Kuomintang's new "1992 Consensus" attempted to split the ROC and the mainland and to sever the connection between Taiwan and the mainland. To some extent, the Kuomintang's new "1992 Consensus" approaches quite near to the idea of Taiwanese Independence. However, under the framework of the Constitution of the ROC, Taiwan maintains that it will neither resort to the use of force, nor declare independence or reunification. For the mainland, the current Ma administration's standpoint is greatly more palatable than the outright advocacy of independence. Furthermore, Ma Ying-jeou's government has also repeatedly announced that against the backdrop of the current acceleration of the globalization process, any attempt to ensure democracy and the prosperity of the economy and society by separatist activities is undesirable. Also, Taiwanese independence is not the only way to achieve Taiwanese democracy and economic prosperity. According to Ma, Taiwan should open up as much as possible, and try to arrive at reconciliation with the Mainland so as to build a platform for mutual negotiations and communication (Shen, 2009). Additionally, after Ma took office, the endeavours he undertook to promote cross-strait economic communication and cooperation have also held forth good prospects for peaceful development across the Taiwan Strait. With the increasing implementation of ECFA, communication and cooperation in business, trade, culture and other aspects of life between people across the Taiwan Strait will go deeper and 
deeper. Mutual understanding between the two sides will improve and prejudice will weaken. Thus, an effective and applicable way may be hit upon for resolving the Taiwan issue.

However, one problem which cannot be ignored is that currently at this stage of dealing with cross-strait economic issues, both sides admittedly may resort to the employment of "interpretation by both sides" as the important means for and foundation of cross-strait compromise and interaction. However, in the future course of dealing with cross-strait political issues, "interpretation by both sides" may eventually beget perplexity or even form an insuperable paradox which may hinder the future development of cross-strait relations. The scheme of "One China, respective interpretations" and the explanation of "the ROC" proposed by Ma Ying-jeou do not necessarily imply the discovery of a unique type of Taiwanese identity jointly recognized by both sides. On the contrary, to some extent the scheme of "One China, respective interpretations" and its explanation by the ROC have exacerbated cross-strait complexities and caused new divergences to appear with regard to Taiwan's identity for both the mainland and Taiwan.

In fact, the high degree of cross-strait economic interdependence and trade links has induced both sides' political differences to narrow ever more. Both the mainland and Taiwan are approaching the baseline of their respective policies. In the event of a significant increase in the probability of political conflict, how the two sides explore the feasibility of tolerance and so arrive at a fundamental direction and method with which to eliminate cross-strait political deadlock and the predicaments inherent in the legal framework of one China will be a test of the political wisdom of the cross-strait governments. Because the mainland government's expansion of and amendment to the connotation of the One China Principle obviously conveys a well-intended message of reconciliation to the Taiwanese authorities from the standpoint of adherence to the One Chin Principle, it is thus undoubtedly beneficial to the peace and stability across the Taiwan Strait.

\subsubsection{A Method of Peaceful Development across the Taiwan Strait: Deepening}




\section{Cross-strait Social and Economic Exchanges and Cooperation}

The foregoing exposition has shown that the mainland's peaceful reunification policy towards Taiwan is largely influenced by the economic construction which lies at the national strategic core. It is said that in the 1980s, Deng Xiaoping once remarked: "Cross-strait economic relations shall realize the goal that there is something of each in the other, and neither can survive without the other, and thus attempts at Taiwanese independence will present [its proponents with] a tough nut to crack". ${ }^{17}$ Reviewing the past 30 years' cross-strait development, this statement is concise as well as comprehensive. Deng Xiaoping's remark about cross-strait relations holds programmatic instructional significance for the mainland's Taiwan policy. The mainland's Taiwan policy has always emphasised the importance of cross-strait economic and trade exchanges, and insisted "that political differences should not affect or interfere with cross-strait economic cooperation" and "that no matter under what circumstances mainland Chinese shall earnestly safeguard all the legitimate rights and interests of Taiwanese business people" (People's News, 2002).

The mainland's policy of hoping to achieve collaborative development and realize China's reunification by means of cross-strait economic integration has also achieved relative success. In 2008, Hu Jintao observed in a speech commemorating the 30th anniversary of the Message to Taiwan Compatriots that "30 years" practice has fully proven that the fundamental Taiwan policy formulated and implemented by our mainland conforms to the tide of the times and the historical trend. The mainland's Taiwan policy grasps fundamental national interests and the state's core interests. The frequent contacts between compatriots across the Taiwan Strait, the intimate economic relationship, active cultural exchanges and the extensive common benefits between the mainland and Taiwan are unprecedented" (Hu, 2009, p.5).

From the course of cross-strait economic and trade exchanges summarized in Chapters Four and Five herein, one may see that the development of the cross-strait

\footnotetext{
17 The authenticity of this remark remains to be verified, and it cannot be verified in the publication of Deng Xiaoping's Thoughts. Mainland scholars do not a give clear indication of provenance when citing this remark. However, this remark is widely known - albeit apocryphal - as Deng Xiaoping's remarks about the essence of cross-strait relations even with the lack of a background to and specific time for this observation.
} 
economy and trade over a long period have depended the evolution of cross-strait political relations. In the past decades, cross-strait relations have presented an apparent instability because of the political isolation between the mainland and Taiwan. Nowadays, it is undeniable that, with the continual deepening of the cross-strait economic and trade development, the political influence on cross-strait relations is correspondingly eroding. The development of a cross-strait economy and trade also infuses serious negative effects into the development of cross-strait political relations. For example Taiwanese business people resorted to circuitous means to flood into the mainland to invest even though by so doing they disregarded restriction from the Taiwanese authorities. Due to the impact of Taiwan business people's insistence on investing in the mainland, various restrictions on such investment decreed by the Taiwanese powers that forced these restrictions to attenuate until, cross-strait economic and trade activities engaged by Taiwan business people eventually became sanctioned and the scope of cross-strait economic and trade exchanges thus escalated. Various policies formulated by the Taiwan authorities to impose restrictions on cross-strait economic development and trade from consideration of political factors suffered assaults from various factors, particularly economic ones. Therefore the Taiwan government's policy of imposing restrictions on cross-strait trade is increasingly difficult to implement and the effects have also been greatly reduced. Moreover, the economic incentive to sign ECFA proves this point further. The high degree of cross-strait economic interdependence compels the Taiwan authority to realize that further normalization of the deviant cross-strait economic relations is more valuable than further liberalization of the economic relations with other countries or regions.

In addition, the personnel, social and cultural exchanges impelled by cross-strait economic and trade exchanges also indicate that the mainland's Taiwan policy of "People first, rather than governments; Economy first, rather than politics" is a wise move. When discussing the role of Taiwanese business people in cross-strait social and cultural exchanges and integration, Chapter Five of this thesis notes that Taiwanese investment in the mainland deepens cross-strait nongovernmental integration. The 
trend of cross-strait integration has developed from an economic level to a social level. It is predictable that with the improvement of cross-strait economic interdependency and the increase of Taiwanese investment, cross-strait exchanges will be in full swing, and the integration of various fields will reach new heights. With the help of cross-strait economic interdependence, the mainland has succeeded in promoting the formation of significant cross-strait exchanges, cooperation and development.

It is in this context that the mainland is advancing the establishment of a cross-strait community of destiny. The mainland's expression of a cross-strait community of destiny indicates that the mainland will continue to promote cross-strait exchanges and cooperation, continue to impel the three direct links, and continue to boost the emotional integration of people across the Taiwan Strait. The mainland will also deepen cross-strait cooperation, appeal to both sides to negotiate a formal end to cross-strait hostility, reach a peaceful agreement on the basis of the One China Principle, and to construct the framework for the peaceful development of cross-strait relations. Although the Taiwan authorities still shy from political negotiations, the successful signing of ECFA, which belongs to the economic field, actually indicates that cross-strait relations have entered into a new stage of institutional consultation and negotiation. ECFA itself has thus long since transcended its mere economic significance.

Therefore, economic interdependence is undoubtedly a key factor which pushes forward the development of cross-strait relations. Historically cross-strait economic and trade relationship have never been a unitary economic problem, but one with a deep tinge of politics from start to finish. There is no denying that to conclude cross-strait relations are peaceful and stable from the high economic interdependence between mainland China and Taiwan is a biased and distorted view. Moreover, the current economic interdependence between mainland China and Taiwan is in a state of extreme asymmetry since Taiwan has long reaped a huge trade surplus from its trade with mainland China. There are two circumstances that dictate that the scope of cross-strait economic and trade cooperation will shrink and become limited, and the depth of cross-strait economic and trade cooperation will certainly contract. Firstly, 
when the international economic situation deteriorates and domestic economic difficulties crop up, the mainland tends to terminate its preferential policies towards Taiwan. Secondly, when Taiwan does not return its goodwill in spite of the mainland's concessive and preferential policies towards Taiwan, the mainland is forced to adopt a more circumspect attitude towards these preferential policies favouring Taiwan.

However people are willing to believe that cross-strait economic interdependence will continually improve cross-strait relations in the light of the past 30 years' cross-strait economic and trade exchanges, the practice of social integration, and the current trend of smooth development. After six decades of development, cross-strait relations are now not merely a matter of emotion and identity, but implicate the more prominent problem of economic interests for many negotiations relating to interests. Therefore, the development of cross-strait economic and trade exchanges, on the one hand, lays a solid material foundation and provides a strong economic momentum for peaceful cross-strait development. On the other hand, cross-strait economic development promotes people-to-people contacts and cultural exchanges across the Taiwan Strait, and enhances mutual trust between the two sides. Therefore strengthening cross-strait economic relations assumes the guise of a possible preparation for further development of future political negotiations between the mainland and Taiwan.

\subsubsection{The Impetus of Peaceful Cross-Strait Development: Relying on the Taiwanese Masses}

Mainland China adheres to the theory of Marxism and Marxism is still taught and used by many officials and scholars. Mainland China holds the view that people create history so that any ruling authority must secure the people's support to stabilise its regime. In accordance with this tenet of Marxist theory, the mainland has always attached great importance to the Taiwanese role in promoting cross-strait reunification. The Message to Taiwan Compatriots renders it evident that mainland China feels bound to set great hopes on ordinary Taiwanese people to achieve cross-strait reunification. 
However, reviewing the work the mainland has done vis-a-vis Taiwan affairs in the past few years, one discovers that the mainland's efforts towards reunifying Taiwanese and mainlanders have had but limited effect, and even the negative effect of recruiting support for the Taiwanese regime. This type of opposite effect found its primary expression in serious disagreements over national identity, and a complex mentality of whether to support independence or one in favour of reunification.

At present, the national identity of the Taiwanese presents a tableau of alienation or diversification. Most Taiwanese acknowledge they are Chinese, but the Chinese people who live in the ROC are all in Taiwan. A small minority opposes the name the "ROC" and wishes to change it because they think the ROC is a non-existent entity, and that it is the PRC, rather than the ROC, that is internationally recognised. Some Taiwanese consider their national identity to be best expressed under the label "Republic of Taiwan". And some people agree with the statement that the ROC is in Taiwan. People who identify the ROC with Taiwan believe it has nothing at all to do with the mainland. As against the PRC, the ROC is consistently regarded as an independent sovereign state by Taiwanese political parties and the masses.

This hybrid national identity of Taiwanese has also influenced their attitude towards cross-strait reunification or independence, and generated a complex and almost schizophrenic state of mind. Taiwanese attitudes towards reunification or independence present an olive shape, being small at both ends and big in the middle. That is to say, there are few people who support outright independence or who are in favour of reunification, while the majority of Taiwanese favour maintaining the status quo (Xie, Dang, Jin, Zeng, Wu, \& Yang, 2006). Most Taiwanese are willing to decide to support unification or independence according to the shifting winds of circumstance. Not only the masses, but the political parties as well tend to uphold the status quo.

In the face of such a situation, the $\mathrm{CCP}$ also realises the urgency of obtaining the support of the Taiwanese masses. Therefore, the mainland has repeatedly stressed that the 23 million Taiwanese are the mainland's blood kin, and constitute an important force for the development of cross-strait economic and cultural exchanges and the expansion of personnel exchanges which represent a significant force countering 
Taiwan separatist forces (Sohu News, 2003). In 2008, President Hu Jintao has noted once again that mainland Chinese should hew to a people-oriented approach, relying on Taiwanese policy in implementing the daily work of Taiwan affairs. Mainland Chinese should not only understand, trust and care about Taiwanese people, but also know their wishes and needs. Moreover, mainland Chinese should ease their difficulties and allay their anxieties, passionately provide more practical and beneficial services for people from Taiwan, protect their legitimate rights and interests in accordance with law, and widely unite Taiwanese to promote the peaceful development of cross-strait relations (Hu, 2009, p.7).

The alienation pervading the Taiwanese national identity is largely due to the long-term isolation between the mainland and Taiwan. Long-term isolation and separation across the Taiwan Strait, together with both the hostile policy of toward one another of the ruling authorities have spawned Taiwanese's unique collective national identity (Hu, 2006). Although the mainland has now adjusted and completely altered its hostile policy towards Taiwan, as against 30 years ago, in Taiwan, from the administration of Lee Teng-hui to that of Chen Shui-bian, the Taiwanese government has constantly bucked the trend of cross-strait peaceful development and advocated Taiwanese independence. Past Taiwanese authorities' anti-reunification and pro-interdependence behaviour has rendered cross-strait relations even more complex to handle.

Therefore, another angle from which to demonstrate the mainland's reliance on the mass Taiwanese policy is that the Chinese government should in the first instance confront the differences subsisting between the two sides in terms of their social systems and their differing values which come as a result of this long-term isolation. In order to elicit the support of the masses of Taiwanese, great efforts should be undertaken to break free from the state of isolation between the two sides, let Taiwanese really understand the present situation in the mainland, and understand the meaning of mainland China's peaceful development policy. Hence, the mainland's espousal of the view that people on both sides of the Taiwan Straits are close flesh and blood and share a common destiny. Both sides across the Strait must cultivate common 
memories of history, culture, economics, and politics by promoting common economic interests. Obviously, the Mainland wants to promote non-governmental and personnel exchanges through cross-strait economic and trade contacts. As a result, the goal of eliminating misunderstanding between people on both sides of the Strait - especially the Taiwanese - by will be achieved enhancing mutual trust and a sense of collective identity and shared destiny

The CCP's policy of relying on the Taiwanese and strengthening cross-strait economic ties is considered a successful policy because the economy has always played an effective role in implementing the mainland's Taiwan policy. Previous improvement and development in the cross-strait relationship was largely promoted by the mainland's proactive policy towards Taiwan. More importantly, the mainland's policies that benefit Taiwanese business people have also produced a good effect. As Chapter Five of the thesis argues, Taiwanese business people who are active in promoting the relationship not only constitute the principal body for cross-strait economic and trade exchanges, but also are the messengers for cross-strait exchanges and communications. A large number of Taiwan business people play an important role in reducing misunderstanding and enhancing mutual trust on both sides. The economic and social effects produced by Taiwanese business people's mainland investment have been exactly on a par with the mainland government's expectations. Massive mainland investment by Taiwan business people has not only laid a solid material foundation for the fusion represented by "you in me, and me in you" as Deng Xiaoping anticipated and improved the sense of identity of people on both sides across the Taiwan Strait, but has also created a positive and harmonious consultative environment for cross-strait political exchanges.

Certainly not all Taiwanese can visit the mainland, so the number of Taiwanese business people is always limited. Therefore, the mainland on the one hand has tried hard to promote cross-strait institutional economic collaboration. For instance, despite the limited benefits which the mainland has gleaned from ECFA, the mainland still actively promoted its signing, and has further devised many preferential policies for Taiwan. The mainland's active attitude towards signing ECFA was consistent with its 
hope of sacrificing part of it national interests to support Taiwanese farmers, and small and medium-sized enterprises in order to gain their support. On the other hand, by making full use of the convenient traffic conditions due to the achievement of the three direct links, both the mainland and Taiwan have actively developed cross-strait tourism. More Taiwanese can have the opportunity to visit the mainland and personally learn of the changes in and development of the mainland following the realization of direct air, sea and postal services.

In summary, the mainland actively promotes cross-strait economic and cultural exchanges to benefit Taiwanese, pushes forward the three direct links, and continually implements and enriches its policies targeting Taiwanese people in the hope of coalescing people's hearts and deepening a cross-strait collective identity. A mutual recognition based on common interests and memories can provide the most solid spiritual levee to contain the separatist trend, thicken the unity of will, and eliminate political differences.

\section{Summary}

This chapter mainly focuses on the mainland's new policy towards Taiwan, known as the peaceful development policy. CCP president $\mathrm{Hu}$ Jintao's speech to the conversazione held in commemoration of the $30^{\text {th }}$ anniversary of the issue of the Message to Taiwan Compatriots at the end of 2008 is not only a summary of the CCP's policy towards Taiwan over the past 30 years, but also regarded as mainland China's newest policy towards Taiwan. This chapter analyzes the target of the mainland's peaceful development policy towards Taiwan as the realization of final cross-strait reunification. The political basis for the peaceful development of cross-strait relations is the One China Principle. The method of realizing peaceful development between the two sides is through deepening cross-strait social and economic exchanges and cooperation by relying on the mass of the Taiwanese people.

The peaceful development policy towards Taiwan puts forward the general plan of a common cross-strait destiny, and fully affirms the position and role of non-governmental forces from the perspective of cross-strait society. By constructing a 
cross-strait cooperative mechanism, the mainland hopes to promote the formation of daily life connecting people on both sides of the Taiwan Strait and gradually eliminating disputes among various ethnic groups on the two sides. More importantly, the mainland hopes to forge common historical memory and emotional condition on the basis of common life experiences between mainland Chinese and Taiwanese. Therefore, the cross-strait cooperative mechanism will provide a solid foundation for the collective identity between the two sides and the further development of cross-strait relations. 


\section{Chapter 7 Conclusion}

This thesis studies cross-strait economic interdependence and cross-strait relations and argues that there is an inherent interactive relationship between cross-strait economic interdependence and cross-strait political relations. This thesis views affairs from the angle of neoliberalist theory and interdependency theory. It also studies the basis of the developmental course of cross-strait economy and trade as well as cross-strait relations. In the past few chapters, this thesis has analyzed the interactive effect between the cross-strait economy and cross-strait relations, especially the political relations from many aspects with the signing of ECFA. The impact of Taiwan business people's mainland investment is the other focus of this research. At the end of this thesis, it concludes that, on the one hand, the increase in cross-strait economic interdependence will promote peace and stability across the Taiwan Strait. On the other hand, stable cross-strait relations will also provide a policy guarantee and a peaceful scope for economic and trade development between mainland China and Taiwan.

Engels once expressed the idea that political power is just the means used to realize economic interests (Li, 2010). Economic interests are the lifeblood of the survival of a country or region and its development foundation. Although cross-strait political relations cannot simply boil down to the influence of economic factors, the general trend is that maintaining normal economic and trade relations with the mainland is very important for Taiwan. As a non-economic factor, cross-strait relations which influence investors' confidence in Taiwan cannot be overlooked. In order to retain its legitimacy, any Taiwanese political party, irrespective of whether the KMT or the DPP, has to consider the Taiwanese people's common interests which are closely related to the increasing cross-strait economic exchanges. Therefore, it may be claimed that cross-strait economic and trade relations are a force countering Taiwan separatist forces. According to the scholar Wang Jianmin, the development of cross-strait economic and trade relations is a beneficial mechanism for maintaining the framework of cross-strait peace and stability (Wang, 2009). Without the beneficial foundation of cross-strait 
economic exchanges and cooperation, cross-strait peaceful development is only a political slogan, and cannot stand as the operating mechanism for future cross-strait relations.

The deduction that both sides across the Taiwan Strait will gradually establish tacit understanding and consensus with deepening cross-strait economic cooperation and development is a rather facile one. Therefore cross-strait political opposition will be resolved on the basis of mutual trust. In the past 30 years since the end of the Cold War, and against the backdrop of economic globalization and regional economic integration, all countries in the world with differing social systems and ideologies may weaken the contentions that spur ideological confrontations, cooperate with others and create multi-win situations for the purpose of safeguarding their own benefits and seeking self development. Undoubtedly, the two sides across the Taiwan Strait which share the same ancestry can dissolve misunderstanding, eliminate estrangement, abandon enmity and end the state of hostility (Yu, 2009). Therefore, peace and stability will become the mainstream of future cross-strait relations. As to what the neorealist theory had to admit that "in recent times, states often get more benefits by enhancing economic efficiency, cooperation and international division of labour other than war, imperialism and the exclusive economic form" (Gilpin, 1994, p.219).

Cross-strait relation is one of the most important and sensitive issues in world politics today, especially in the Asia-Pacific region. The healthy cross-strait development not only concerns peace and happiness of people from both sides across the Taiwan Strait, but also the security, stability and development of the Asia-Pacific region, the United States and even the whole world. If cross-strait relations are compared to a living organism, then in this organism, political relations are the framework and physique, economic and trade relations are the flesh and blood, cultural relations are the soul and skin, and cross-strait people, especially Taiwanese business people are the red blood cells which transport oxygen and nutrition for this organism.

The past 60 years' course of trials and hardship of cross-strait relations have demonstrated that, without the guarantees of such a framework as political relations, 
the flesh and blood economic and trade relations have nowhere to abide, and spiritual cultural relations can only exist in an unseen world. In return, in the absence of the flesh and blood of economic and trade relations, the framework of political relations can only be a skeleton. Fortunately, cross-strait economic and trade relations as well as political relations have developed remarkably since the late 1980s, and this organism of cross-strait relations is rapidly developing and becoming mature on account of its careful handling by cross-strait people and governments. Nowadays cross-strait relations are in the midst of a period of fast development motivated by economy and trade. How to strengthen its physique and to solve the cross-strait political issue smoothly are difficult problems which will test the wisdom of cross-strait people and statesmen, and which needs both sides to cooperate actively and participate jointly.

In the cross-strait political and economic relations divergence exists, however cross-strait mutual dependence and security accord with the interests of people from both sides. People hope that the newborn entity of cross-strait relations will grow up strong and sturdy in the post-ECFA era. Certain encouraging developments should serve to bolster and validate this expectation, such as the cessation in recent years of provocative military manoeuvres in the vicinity and missile test firings into the straits, as well as increasing political liberalism in the PRC government, which, coupled with the resurgent economic might of the mainland, may serve to offer additional inducements for the Taiwanese to eschew their separatist tendencies and opt for reunification in the short term. However the situation eventually plays out, it is safe to assert that, absent some wholly unforeseeable event that triggers a renewed escalation of hostilities, the two sides across the Strait seem to be charting a convergent course that will eventually and ineluctably result in their economic and political union. Whether this occurs in the near or the long term will rest in the final analysis on the goodwill and sincerity of the two sides, and the willingness to compromise and adapt, the lack of which 60 -odd years ago precipitated the rift that has dogged relations since, and which rested ultimately on the personal inflexibility and divergent world views of the two chief protagonists who divided China, Mao Zedong and Chiang Kai-shek. It is 
up to their progeny - both political and genetic - to repair the damage that their intractability and mutual, personal antagonism wrought on the Chinese nation, a consummation which is both devoutly to be wished, and far, far too long overdue. 


\section{References}

Baldwin, D. A. (1980). Interdependence and Power: A Conceptual Analysis. International Organization, 34 (4), 471-506.

BBC. (2010). Taiwan president upbeat on efforts to improve cross-strait ties. Retrieved from http://proquest.umi.com.helicon.vuw.ac.nz/pqdweb?did=2033019041\&sid=3\& Fmt $=3 \&$ clientId $=7511 \&$ RQT $=309 \&$ VName $=$ PQD.

Beijing Morning Post (北京晨报). (2008, June 11). The Number of Cross-strait Marriages Has Reached to 308 Thousands Pairs (海峡两岸婚姻已逾 30.8 万 对). Beijing Morning Post (北京晨报), p. A10.

Cai, J., \& Chen, Y. J. (蔡洁, 陈军亚). (2011). The Impacts of Sino-US Trade Developments on the Two Countries' Political Relationship (中美贸易发展对 两国政治关系的影响). Economic Review (经济评论), 3, 117-123.

Cain, P. (1979). Capitalism, War and Internationalism in the Thought of Richard Cobden. British Journal of International Studies, 5 (3), 229-247.

Caijing Network. (财经网). (2009). Taiwan Announces the Result of the Evaluation of ECFA (台湾公布 ECFA 效益评估结果). Retrieved from http://www.caijing.com.cn/2009-07-30/110218630.html.

Cao, X. H. (曹小衡). (2008). The Cross-straits Economy Integration Progress and Prospect (两岸经济一体化的进展与前景). Asia-Pacific Economic Review (亚 太经济), 2, 95-99.

$\begin{array}{llllll}\text { Carpenter, } & \text { T. } & \text { G. (2010). Taiwan Strait. Retrieved from }\end{array}$ http://www.cato.org/pub_display.php?pub_id=11111.

CCTV News. (央视网). (2002). Why Has Taiwan's Competitive Power Decreased (台 湾竞争力排名为何下降). Retrieved from http://www.cctv.com/lm/523/51/67581.html.

CCTV News. (央视网). (2003). J. P. Morgan: the Reason Why China Attracts Foreign Investment Has Not Changed (摩根大通认为中国吸引外资的根本原 因 未 变 ) . Retrieved from 
http://www.cctv.com/financial/special/C10677/20030704/101588.shtml.

Chao, L., \& Myers, R. H. (2000). The Divided China Problem: Conflict Avoidance and Resolution. Stanford: Hoover Institution Press.

Chen, B. S. (陈宝森). (1999). The World Competition of American Trans-national Corporations (美国跨国公司的全球竞争). Beijing, China: Chinese Academy of Social Sciences Press.

Chen, E. (陈恩). (2005). Study on the Change of Taiwan Business People's Political Life and Their Preference of Political Party in the New Century (新世纪台商 的政治生态变化和政党认同价值取向探析). Southeast Asian Studies (东南亚 研究), 1, 43-47.

Chen, J. Z. (陈建仲). (2004). Taiwan Business People Group - A Giant Wandering between the Mainland and Taiwan Political Powers（台商集团——徘徊在两 岸当局间的巨人). Strait Review (海峡评论), 159, 23-26.

Chen, J. S. (陈建诗). (2010, December 4). Similarities Appears between the Blue Camp and Green Camp's Mainland Policy (蓝绿两岸政策有趋同迹象). Unity Newspaper (团结报), p.3.

Chen, X. C. (陈先才). (2008). Opportunities and Challenges after Ma Ying-jeou Took Office (马英九上台: 两岸关系面临的机遇和挑战). Theory Consultation (理 论参考), 6, 9-11.

Chen, Z. M., \& Cui, D. W. (陈志敏, 崔大伟). (2006). International Political Economy and China's Globalisation (国际政治经济学与中国的全球化). Shanghai, China: Shanghai San Lian Book Store.

Cheng, W. (程伟). (1996). A Brief Discussion about the Development and Effects of APEC (简论 APEC 的发展过程及其作用). Contemporary Economy of Japan (现代日本经济), 4, 42-45.

China Economic and Social Development Database. (中国经济社会发展统计数据 库). (2011). Social and Economic Indicators about Taiwan (台湾省主要社会 经济指标 ). Retrieved from http://tongji.cnki.net/kns55/navi/result.aspx?id=N2011060008\&file=N2011060 $\underline{008000254 \& \text { floor }=1}$. 
China External Economic Statistical Yearbook Editorial Committee (中国对外经济贸 易年鉴编辑委员会). (1993). China External Economic Statistical Yearbook 1993 (中华人民共和国对外经济贸易年鉴1993 年). Beijing: China External Economic Press.

China News. (中新网). (2000). Rebuttal to Lee Teng-hui’s “Two States Theory” (驳李 登辉的“两国论”). Retrieved from http://www.chinanews.com/2000-3-9/26/21225.html.

China News (中新网). (2008). Current Trajectory of the Development of Cross-strait Relations is Anti-interdependence, Pro-peace and Gradual Reunification (当前 两岸关系发展轨迹是反独、促和、渐统). Retrieved from http://www.chinanews.com/tw/dlyw/news/2008/07-09/1307331.shtml.

China News. (中新网). (2010a). Cross-Strait Economic Cooperation Framework Agreement (海峡两岸经济合作框架协议). Retrieved from http://www.chinanews.com/tw/2010/06-29/2370171.shtml.

China News. (中新网). (2010b). The Fifth Meeting between Leaders across the Taiwan Strait Was Held in Chongqing (两岸两会在重庆举行第五次领导人会 谈). Retrieved from http://www.chinanews.com/tw/2010/06-29/2370461.shtml. China Taiwan Organization. (中国台湾网). (2004). In 1995 President Jiang Zemin Proposed Eight Proposals on the Development of Cross-strait Relations and the Peaceful Reunification of China (江泽民就发展两岸关系、推进祖国和平 统一进程提出的八项主张，1995 年). Retrieved from http://www.chinataiwan.org/zt/szzt/taidumeiyouheping/bjzl/200801/t20080102 518632.htm.

China Taiwan Organisation. (中国台湾网). (2010). The Signing of ECFA - To Create a Sustainable Development Environment for Taiwan's Economy (签署 $E C F A$ 一为台湾经济开创永续发展大环境). Retrieved from http://www.chinataiwan.org/plzhx/mtshy/tga/zhyrb/201001/t20100113_122006 2.htm.

Chinese Radio Network. (华语广播网). (2010). The Signing of ECFA Marks A New Beginning of Economic Cooperation and Development between Mainland 
China and Taiwan (ECFA 的签署开创两岸经济合作与发展新格局).

Retrieved from http://gb.cri.cn/24384/2010/07/07/3705s2912820.htm.

Chung, O. (2008). Closer than Ever. Taiwan Review, 58(12), 3.

Chung, O. (2010). Leading Taiwan to a Better Tomorrow. Taiwan Review, 60(6), 1.

Chung, O. (2008). Closer than Ever. Taiwan Review, 58(12), 3.

Edmonton Journal. (2010). Jiabao Longs to Visit Taiwan. Retrieved from http://proquest.umi.com.helicon.vuw.ac.nz/pqdweb?did=1984398911\&sid=8\& Fmt $=3 \&$ clientId $=7511 \&$ RQT $=309 \&$ VName=PQD.

EIU ViewsWire. (2010). Taiwan/China Politics: ECFA Remains Controversial. Retrieved from http://proquest.umi.com.helicon.vuw.ac.nz/pqdweb?did=2013253971\&sid=9\& Fmt $=3 \&$ clientId $=7511 \&$ RQT $=309 \&$ VName $=P Q D$.

Fan, Q. F. (范前锋). (2008). Prospects for Reunification between Mainland China and Taiwan from the Perspective of Power Contrast - Written in the $20^{\text {th }}$ Anniversary of the Opening of Cross-strait Communication (从实力对比变化 看两岸统一前景——写在两岸开放交流 20 周年之际). Journal of Guangzhou Institute of Socialism (广州社会主义学院学报), 20, 52-54.

Fei, X. T. (费孝通). (2001). Jiangcun Economy (江村经济). Beijing, China: The Commercial Press.

Friedberg, A. (1993). Ripe for Rivalry: Prospects for Peace in a Multipolar Asia. International Security, 18 (3), 5-33.

Fu, L. (2008). As Hazy as Ever, the Cross-strait Status Quo. Georgetown Journal of International Affairs, 9 (2), 141-147.

Gilley, B. (2010). Not So Dire Straits. Foreign Affairs, 89(1), 44-59.

Gilpin, R. (1994). War and Change in World Politics (J. Wu, Trans). Beijing, China: China Renmin University Press.

Gilpin, R. (2001). Global Capitalist Challenges - Global Economy in the 21 Century (G. Y. Yang, \& J. Yang, Trans). Shanghai, China: Shanghai People's Press.

Grieco, J., \& Ikenberry, J. (2008). State Power and Global Market (Z. P. Wang, Trans). Beijing: People's University Press. 
Gu, X. (古雪). (2010). 70\% Mainland People Wish to Visit Taiwan for Tourism (七成 大陆民众愿意赴台旅游). Marketing Research (市场研究), 2, 20-22.

Guo, J. (郭洁). (2008). Relationship between Economic Globalisation and Regionalisation (经济全球化与区域经济一体化的关系). Journal of Beijing Vocational \& Technical Institute of Industry (北京工业职业技术学院学报), 7 (4), 129-123.

Guo, J. F. (郭建芳). (2005). Discussion about the Inaccurate Taiwan People's National Identity (试论台湾人的国家认同错位). Journal of Chongqing Institute of Socialism (重庆社会主义学院学报), 4, 57-59.

Guo, J. W. (郭继武). (1999). China and Asia Pacific Economic Cooperation (中国与 亚太经合组织). China Business Monthly (中国经贸), 3, 44-45.

Hai, X. (海啸). (1999). “Two States Theory” is “A Theory of Betrayal” (“两国论”就 是“叛国论”). Reunification Forum (统一论坛), 5, 14-15.

He, L. (何流). (2010). ECFA-Why the Mainland Offers More Benefits to Taiwan? (大 陆为什么要给台湾让利?). China Report (中国报道), 4, 59-60.

Hickey, D. V. V. (1999). Taiwan Independence: Image and Reality. Retrieved from http://www.taiwansecurity.org/IS/Hickey-Taiwan-Independence-Image-and-Re ality.htm.

Hirschman, A. O. (1977). The Passions and the Interests: Political Arguments for Capitalism before Its Triumph. Princeton: Princeton University Press.

Hirschman, A. O. (1980). National Power and the Structure of Foreign Trade. Berkeley: University of California Press.

Hobbes, T. (1968). Leviathan. Harmondsworth, UK: Penguin Books Ltd.

Holsti, K. J. (1986). Politics in Command: Foreign Trade as National Security Policy. International Organization, 40, 643-671.

Hsiao, H. M., \& So, A. Y. (1996). The Taiwan-Mainland Economic Nexus: Sociopolitical Origins, State-Society Impacts, and Future Prospects. Bulletin of Concerned Asian Scholars, 28(1), 3-12.

Hsiung, J. (2009). The Age of Geoeconomics, China's Global Role, and Prospects of Cross-strait Integration. Journal of Chinese Political Science, 14 (2), 113-133. 
Hu, J. T. (胡锦涛). (2009). To Promote Cross-strait Peaceful Development and to Achieve the Goal of China's Great Reunification - President Hu's Speech at the $30^{\text {th }}$ Anniversary of Issuing "Message to Taiwan Compatriots" (携手推动两 岸关系和平发展 同心实现中华民族伟大复兴——在纪念《告台湾同胞书》 发表 30 周年座谈会上的讲话). Relations across the Taiwan Strait (两岸关系), $1,4-7$.

Hu, S. Z., He, M., \& Hong, R. B. (胡胜正，何美，洪瑞涁). (2003). Evaluation and Prospect of Taiwan's Overall Economic Development (台湾总体经济发展评 析与展望). Taiwan Economic Forum (台湾经济论衡), 1 (10), 1-28.

$\mathrm{Hu}$, W. S. (胡文生). (2006). The Origin, History and Reality of the Problem of Taiwan People’s “National Identity” (台湾民众“国家认同”问题的由来、历史 及现实). Journal of Beijing Union University, Humanities and Social Science Edition (北京联合大学学报, 人文社会科学版), 4 (2), 83-88.

Hu, X. H. (胡笑红). (2010, June 26). The Mainland Will Reduce Tariff on 539 Items from Taiwan and Open 11 Trade in Services for Taiwan Investors, such as Hospital, Banking, Insurance and others (大陆将对台湾 539 项产品降税同时 将开放医院、银行、保险等 11 个行业). Beijing Times (京华时报), p.26.

Hua, M., Wang, J. H., \& Zhou, H. Y. (华民, 王疆华, 周红燕). (2002). Internalisation, Economic Regionalisation and Economic Globalisation（内部化、区域经济一 体化与经济全球化). World Economics and Politics (世界经济与政治), 12, $39-42$.

Huang, H. (黄河). (2008a). Trans-national Corporation and the Contemporary International Relations (跨国公司与当代国际关系). Shanghai, China: Shanghai People's Press.

Huang, H., Zhuang, H. N., Huang, H. X., Liu, X. H., Yu, B. C., \& Liu, J. H. (黄海, 庄 会宁, 黄海霞, 刘心惠, 于滨采, 刘敬怀). (2002). Chen Shui-bian Plays with Fire (陈水扁玩火). Tiaowang News Weekly Publication (䀥望新闻周刊), 33, 6-16.

Huang, J. G. (黄建钢). (2008b). Economic Politics (经济政治学). Zhejiang, China: Zhejiang University Press. 
Huaxia News. (华夏经纬网). (2009). Desire to Account for All Cheap While Afraid of Suffering Losses (想要占尽便宜又害怕吃亏). Retrieved from http://www.huaxia.com/zk/thsd/wz/2009/03/1336176.html.

Ide, W. (2010). Taiwan, China Open First Semi-Official Offices. Retrieved from http://proquest.umi.com.helicon.vuw.ac.nz/pqdweb?did=2032238941\&sid=1\& $\underline{\text { Fmt }=3 \& \text { clientId }=7511 \& R Q T=309 \& \text { VName }=P Q D}$.

Jia， Q. L. (贾庆林). (2005). To Deepen and Expand Cross-strait Economic Cooperation and Promote Cross-strait Peace and Stability - Speech on the First Cross-strait Civil Elite Forum (全面深化和扩大两岸经济交流与合作努力促 进两岸关系朝着和平稳定的方向发展一一在第一届两岸民间著英论坛开 幕式上的演讲). Relations across the Taiwan Strait (两岸关系), 10, 6-9.

Jin, H. F. (金影峰). (2010). A Research on ECFA and Mainland Enterprises' Taiwan Strategy (ECFA 与中国内地企业对台战略研究). Market Modernisation Magazine (商场现代化), 12, 5-7.

Johnston, A. I., \& Ross, R. S. (Eds.). (1999). Engaging China: The Management of An Emerging power. London and New York: Routledge.

Jonathan, A. (2010). Taiwan Welcomes China's Tourism Boom. But Chinese tourists, $\begin{array}{llll}\text { not } & \text { so } & \text { much } & \text { Retrieved }\end{array}$ http://proquest.umi.com.helicon.vuw.ac.nz/pqdweb?index $=0 \&$ did=2076122431 $\&$ SrchMode $=2 \& \operatorname{sid}=12 \&$ Fmt $=3 \&$ VInst $=$ PROD $\&$ VType $=$ PQD $\&$ RQT $=309 \& V$ $\underline{\text { Name }=P Q D \& T S=1281392668 \& \text { clientId=7511\#indexing. }}$.

Keohane, R. O. (1984). After Hegemony: Cooperation and Discord in the World Economy. Princeton: Princeton University Press.

Keohane, R. O. (1986). Reciprocity in International Relations. International Organization, 40 (1), 1-27.

Keohane, R. O. (1990). International Liberalism Reconsidered. In J. Dunn (Ed.), The Economic Limits to Modern Politic (pp.165-194). Cambridge: Cambridge University Press.

Keohance, R. O., \& Nye, J. S. (1989). Power and Interdependence (2nd ed.). New York: Harper Collins Publishers. 
Krasner, S. D. (Ed.). (1983). International Regimes. Ithaca, Greece: Cornell University Press.

Lebow, R. N. (2007). Classical Realism. In T. Dunne, M. Kurki, \& S. Smith (Eds.), International Relations Theories: Discipline and Diversity (pp.52-70). Oxford, UK: Oxford University Press.

Lee, T. (1999). Responses to Questions Submitted by Deutsche Welle. In Republic of China, government Information Office, comp, Getting Real: International Media Perspectives on the Special State-to-State Relationship between the ROC and the PRC (pp. 26-33). Taipei: Government Information Office.

Leng, T. (1998). A Political Analysis of Taiwan's Economic Dependence on Mainland China. Issues \& Studies, 34 (8), 132-154.

Li，A. H. (李爱华). (2010a). Li Aihua: A Discussion about Marx and Engels' Opinions on National Interests (李爱华: 论马克思恩格斯的国家利益观). Retrieved from http://www.21ccom.net/articles/sxpl/sx/article_2010083117285.html.

Li, F. (李非). (2004). General Discussion about Taiwan Economic Development (台 湾经济发展通论). Beijing, China: Jiuzhou Press.

Li, F. (李非). (2005a). Essence of 25 Years Taiwan Research - Cross-strait Edition (台湾研究 25 年精粹—两岸篇). Beijing, China: Jiuzhou Press.

Li, F. (李非). (2008). Development and Transformation of Taiwan Business People on the mainland (台商在大陆的发展与转型). Development Research (发展研究), 2, 39-41.

Li, F. (李非). (2009). Peaceful Development Is the eternal Theme for Cross-strait Relations - For the $30^{\text {th }}$ Anniversary of Issuing "Message to Taiwan Compatriots” (和平发展是两岸关系的永恒主题——纪念《告台湾同胞书》 发表三十周年). Political Consultative World (政协天地), 2, 82-83.

Li, L. S. (李隆生). (2005b). A Research about the Impacts of Taiwan Business People's Direct Investment to the Mainland on Taiwan's Economy from 1991 to 2003 (1991—2003 台商大陆直接投资对台湾经济的影响研究). 
Southeast Academic Research (东南学术), 4, 140-147.

Li, Q. S. (李庆四). (2002). Sino-US Relations under APEC Mechanism (APEC 机制 下的中美关系). International Forum (国际论坛), 4 (1), 18-24.

Li, Y. (李扬). (2003). An Analysis of the Influence of Technical Efficiency to Small and Medium-sized Taiwan Enterprises’ Overseas Investment (技术效率对台湾 中小企业海外投资影响之分析). Asia Pacific Review of Social Science and Technology (亚太社会科技学报), 2 (2), 117-130.

Li, Y. L. (李韵琳). (2010b). ECFA - A Historical Agreement beyond Economic Significance (超越经济意义的历史性经合协议一一台海两岸正式签署 ECFA). $\quad$ Retrieved from http://www.zaobao.com/special/china/taiwan/pages13/taiwan100630b.shtml.

Li, Y. X., Luo, D. J., \& Zhao, Y. Z. (李元旭, 罗殿军, 赵优珍). (2002). Trans-national Corporation and International Political Order (跨国公司与国际政治秩序). Shanghai Management Science (上海管理科学), 1, 35-40.

Lin, C. D. (林承铎). (2009). A Research About Some Related Problems of ECFA From the Perspective of How to Overcome Cross-strait Political and Legal Barriers (两岸经济合作架构协议相关问题研究——以如何排除政治、法律 障碍为基点). International Economic Review (国际经济评论), 5, 62-64.

Lin, J., \& He, Z. M. (林娟, 何祖谋). (2011, May 18). The Mainland and Taiwan Seek Win-Win Situation after the Appearance of Early Results of ECFA (ECFA 成效 初显两岸共谋双赢). Fujian Daily( 福建日报), p.2.

Lin, Q., Yang, F. L., Lin, K. T., \& Li, B. Z. (林卿, 杨飞龙, 林孔团, 李碧珍). (2008). Cross-strait Economic Cooperation: Innovation and A Win-win Situation - A Review about the Second Cross-strait Economic Development Forum (海峡两 岸经济合作：创新与双赢——第二次海峡两岸经济发展论坛综述). Development Research (发展研究), 8, 71-75.

Lin, Y. F., \& Yi, Q. L. (林毅夫，易秋霖). (2006). The Trend of Cross-strait Economic Development and Trade Cooperation (海峡两岸经济发展与经贸合作趋势). International Commerce Issues (国际贸易问题), 2, 5-18. 
Ling, G. L. (凌国良). (2002). Review the “1992 Consensus” (回眸“九二共识”). Reunification Forum( 统一论坛), 5, 53-55.

Liu, A. C., Zhang, Y. Y., \& Cheng, G. (刘爱成, 张依瑶, 程刚). (2004, January 30). Whom will Taiwan Business People Vote for (台商会投谁的票). Global Times (环球时报), p.1.

Liu, B., \& Bian, P. (刘斌, 边鹏). (2009, October 28). ECFA Does Not Cover Equality and Mutual Benefit, But Only Covers Sole Benefit to Taiwan (ECFA 不是平等 互惠，而是片面最惠). Southern Weekend (南方周末), p. B7.

Liu, G. (刘舸). (2011). The Contents of Cross-strait Economic Cooperation Mechanism and Its Developmental Pattern (两岸经济合作机制的内涵及其成 长规律). Journal of Anhui Normal University, Humanities and Social Science Edition (安徽师范大学学报, 人文社会科学版), 38 (1), 66-70.

Liu, J. X., \& Gao, L. P. (刘建兴, 高立平). (2004). Taiwan Business People-the Main Force of Economic Development (台商——经济发展的生力军). Retrieved from

http://www.chinataiwan.org/tsh/mtxy/tylt/200708/t20070801_405621.htm.

Liu, K. (刘克). (1996). The US' New Economic Strategy in Asia - Utilising APEC to Facilitate the Opening of Asia-Pacific Market (美国的亚洲经济新战略——利 用亚太经合组织促使亚太市场开放). Journal of Lanzhou Commercial College (兰州商学院学报), 1,14-17.

Liu, L. G. (刘利刚). (2010). The Coming of ECFA Time (ECFA - 两岸经济合作框架 协议时代到来 ). Retrieved from http://www.mofcom.gov.cn/aarticle/difang/yunnan/201007/20100707001821.ht $\underline{\mathrm{ml}}$.

Liu, X. J., \& Zu, L. L. (刘小军, 祖林丽). (2011). Changes of American Industrial Policy and Structure after the 1980s and its Enlightenment to China (20 世纪 80 年代以后美国产业政策、产业结构的变化及对我国的启示). The Merchandise and Quality (商品与质量), 3, 28-30.

Liu, Y. Z. (刘延衷). (2009). Contemporary World Economy and International 
Relations (当代世界经济政治与国际关系). Beijing, China: Higher Education Press.

Lu, J. R. (陆建人). (1997). Asia-Pacific Economic Cooperation and China (亚太经合 组织与中国). Beijing, China: Economy \& Management Publishing House.

Lu, X. J., \& Fan, Q. F. (芦新建, 范前锋). (2010). General Opinions Review of the Academic Seminar "Creating a New Phase of Cross-strait Peaceful Development ”(“开创两岸关系和平发展新局面”学术研讨会观点综述). Journal of Hubei Institute of Socialism (湖北省社会主义学院学报), 3, 78-80.

Lv, Y. B., Cheng, S. F., \& Zou, C. Y. (吕玉宝, 程莎锋, 邹春莹). (2008). An Analysis about the Historical Development, Current Structure and Situation of Taiwan Business People's Mainland Investment (台商大陆投资的发展历史及结构现 状分析). Contemporary Economics (当代经济), 12, 37-39.

Mainland Affairs Council. (2003). Visits Across the Taiwan Strait. Retrieved from http://www.mac.gov.tw/public/MMO/MAC/Visits\%20across\%20the\%20Taiwa n\%20Strait.gif.

Martin, L. L. (2007). Neoliberalism. In T. Dunne, M. Kurki, \& S. Smith (Eds.), International Relations Theories: Discipline and Diversity (pp.109-126). Oxford, UK: Oxford University Press.

Marx, K. (1975). Capital: A Critique of Political Economy (Central Compilation \& Translation Bureau, Trans). Beijing, China: People's Press.

McMillan, S. M. (1997). Interdependence and Conflict. Mershon International Studies Review, 41 (1), 33-58.

Mearsheimer, J. J. (1994-1995). The False Promise of International Institutions. International Security, 19 (3), 5-49.

Mearsheimer, J. J. (2007). Structural Realism. In T. Dunne, M. Kurki, \& S. Smith (Eds.), International Relations Theories: Discipline and Diversity (pp.71-88). Oxford, UK: Oxford University Press.

Meng, H., Jiang, H. J., \& Zhao, L. J. (蒙慧, 蒋海蛟, 赵利娟). (2011). The Impacts of ECFA on Sino-US Economic, Commercial and Political Relations - An Angle 
of View from Interdependence Theory (海峡两岸经济合作框架协议 ECFA 对 中美经贸及政治关系的影响——基于复合相互依赖理论的视角). Journal of Lanzhou Commercial College (兰州商学院学报), 27(3), 37-42.

Miao, Y. C. (苗迎春). (2003). Trans-national Corporations Promote Sino-US Strategic Cooperation (跨国公司助推中美战略合作). Retrieved from http://big5.china.com.cn/authority/txt/2003-10/21/content 5425777.htm.

Mingst, K. A. (2008). Essentials of International Relations (4th ed.). New York: W. W. Norton \& Company.

Montesquieu, B. D. (2009). The Spirit of Laws (M. L. Xu, Trans.). Beijing, China: The Commercial Press.

Morgenthau, H. J. (1973). Politics among Nations: the Struggle for Power and Peace (5th ed.). New York: Alfred A. Knopf, Inc.

Mueller, J. (1988). Retreat from Doomsday: the Obsolescence of Major War. New York: Basic Book, Inc.

National Statistical Bureau (国家统计局). (n.d.). China’s Statistical Yearbook (中国 统计年鉴 ). Retrieved from http://tongji.cnki.net/kns55/Navi/HomePage.aspx?id=N2010100096\&name=YI $\underline{\text { NFN\&floor }=1 .}$.

National Statistical Bureau (国家统计局). (n.d.). China's External Economic Statistical Yearbook (中国对外经济统计年鉴). Retrieved from http://tongji.cnki.net/kns55/Navi/HomePage.aspx ?id=N2006090328\&name=Y $\underline{\text { DWJJ\&floor }=1}$.

National Statistical Bureau. (国家统计局). (2011). Report on the Social and Economic Achievements during the $11^{\text {th }}$ Five Year Plan (十一五经济社会发展 成 就系列报告之一 ). Retrieved from http://www.stats.gov.cn/was40/gjtij_detail.jsp?searchword=\%B9\%FA\%C4\%D A\%C9\%FA\%B2\%FA\%D7\%DC\%D6\%B5\&channelid=6697\&record=65.

Niu, Z. J. (牛智敬). (2009, April 20). Interview with Mr. Wang Yi, Director of Taiwan Affairs Office of the State Council PRC: Meetings between Chen Yunlin and 
Jiang Bingkun May Start Cross-strait Economic Negotiation Mechanism (专访 国台办主任王毅：陈江会可启动两岸商谈经济合作机制). China Business News (第一财经日报), p.16.

People's Daily. (2005). Full Text of Anti-secession Law. Retrieved from http://english.peopledaily.com.cn/200503/14/eng20050314_176746.html.

People's Daily (人民日报). (2007, June 5). The Community of Taiwan Business People Appeal Mainland Taiwan Businessmen to Go Back to Taiwan for Taiwan Presidential Election (台商组织呼吁大陆台商回岛投票). People's Daily, p.3.

People's News. (人民网). (2002a). Chen Shui-bian Says Taiwan Will Adopt Active, Open Attitude and Efficient Management Instead of Being Patient Policy Towards the Mainland (陈水扁称：以“积极开放、有效管理“取代“戒急用 忍”). Retrieved from http://tw.people.com.cn/GB/14812/14874/897685.html.

People's News. (人民网). (2002b). Jiang Zemin: Continue to Make Efforts for Promoting the Reunification of China (江泽民: 为促进祖国统一大业的完成 而继续 奋 $\quad *$ ). Retrieved from http://tw.people.com.cn/GB/14864/14918/885617.html.

People's News. (人民网). (2005). Hu Jintao and Lian Zhan Held Formal Talks in Beijing (胡锦涛和连战在北京举行正式会谈). Retrieved from http://politics.people.com.cn/GB/1026/3361296.html.

QQ News. (腾讯网). (2010). Taiwan's Foreign Exchange Reserve Ranks the Fourth in the World (台湾外汇储备排名世界第四). Retrieved from http://news.qq.com/a/20100805/002165.htm.

Ricardo, D. (2011). On the Principles of Political Economy and Taxation (D. L. Guo., \& Y. N. Wang, Trans). Shanghai, China: Yi Lin Press.

Rogowski, R. (1989). Commerce and Coalitions: How Trade Affects Domestic Political Alignments. Princeton: Princeton University Press.

Rosecrance, R. (1986). The Rise of the Trading State: Commerce and Conquest in the Modern World. New York: Basic Books, Inc. 
Roy, D. (2003). Taiwan: A Political History. Ithaca and London: Cornell University Press.

Shan, X. J. (单小洁). (2009). Strengthen Cross-strait Economic Exchange and to Promote Earlier Reunification between the Mainland and Taiwan (加大两岸经 济交流促两岸早日统一). Manager'Journal (经营管理者), 24, 215.

Shanghai WTO Affairs Consultation Centre. (上海 WTO 事务咨询中心). (2011). American Peterson Institute Announces the Evaluation Report of "Impacts of ECFA to the Two Sides” (美国彼得森研究所公布《ECFA 对诸方的影响》评

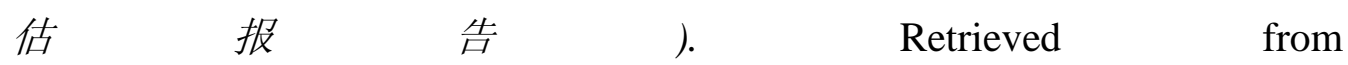
http://www.sccwto.net/webpages/WebMessageAction_viewIndex 1.action?men uid=FDAAAD4B2B89483C92A4DEEAB4640CB3\&id=9e9ee46f-dd6c-4315a219-56615bd2f4f4.

Shen, Y. M. (沈言明). (2009). Cross-strait Relations after Ma Ying-jeou Took Office (论马英九执政后的两岸关系). Journal of Chongqing University of Science and Technology, Social Science Edition (重庆科技学院学报社会科学版), 5, 22-23.

Shi, W. J. (石文静). (2002). Studies On Ways of Uniting Taiwan People by Relying on Taiwan Business People (依靠台商做好台湾民众工作的途径探讨). Journal of Chinese Communist Party School of Xiamen (厦门特区党校学报), $14(6), 44-46$.

Shi, Z. L., \& Huang, T. (施祖麟, 黄涛). (2007). An Empirical Analysis and Developmental Prospect of the Characteristics of Taiwan Business People's Investment to the Mainland (台商对大陆投资特点的实证分析与发展展望). Journal of Tsinghua University, Philosophy \& Social Science Edition (清华大 学学报, 哲学社会科学版), 22 (4), 137-144.

Sina News. (新浪网). (2001). Mainland China Becomes Taiwan's No.1 Tourist Destination with Mainly Business Tourists Arrival to the Mainland (大陆成台 湾最大旅游市场, 商务类游客为主). Retrieved from http://finance.sina.com.cn/g/78065.html. 
Sina News. (新浪网). (2004). Taiwanese Business People on the Mainland Initiates "Love Hometown Programme" and Thousands of Them Return to Taiwan for the Presidential Election (在大陆台商发起“爱乡项目”万人包机返台投票). Retrieved from http://news.sina.com.cn/c/2004-01-14/09341583124s.shtml.

Sina News. (新浪网). (2006). Taiwan Industrial and Business Community Urges Taiwan authorities to Adopt a Flexible and Pragmatic Approach to the Mainland (台工商界吁台当局在两岸关系上应采弹性务实做法). Retrieved from http://mil.news.sina.com.cn/2006-08-01/1037387608.html.

Smith, A. (2009). An Inquiry into the Nature and Causes of the Wealth of Nations (D. L. Guo., \& Y. N. Wang, Trans). Shanghai, China: Shanghai San Lian Book Store.

Smith, R. B. (2007). Changing Visions of East Asia, 1943-93: Transformations and Continuities. New York: Routledge.

Sohu News (搜狐网). (2003). Hu Jintao: Adhere to Peaceful Reunification and the One Country, Two Systems Policy to Resolve the Taiwan Problem (胡锦涛: 坚 持和平统一、一国两制解决台湾问题). Retrieved from http://news.sohu.com/00/47/news207014700.shtml.

Sohu News. (搜狐网). (2004). Statistics from Taiwan Show the Mainland Has Become Taiwan's Largest Trading Partner (台方统计显示: 大陆首度成为台湾最大贸

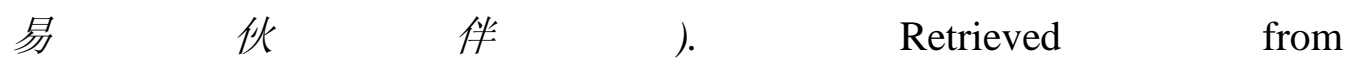
http://news.sohu.com/2004/03/02/65/news219266559.shtml.

Sohu News. (搜狐网). (2005). German Newspaper Reports: Millions of Taiwan Business People Makes Cross-strait Relations Inseparable (德报: 百万台商使 两岸关系密不可分). Retrieved from http://news.sohu.com/20050321/n224785646.shtml.

Song, X. N., \& Chen, Y. (宋新宁, 陈岳). (2001). Introduction of International Politics (国际政治学概论). Beijing, China: China Renmin University Press.

State Department Documents. (2010). Background Notes: Taiwan. Retrieved from http://proquest.umi.com.helicon.vuw.ac.nz/pqdweb?did=2032051221\&sid=4\& Fmt $=3 \&$ clientId $=7511 \&$ RQT $=309 \&$ VName $=$ PQD. 
Stein, A. A. (1983). Coordination and Collaboration: Regimes in an Anarchic World. In S. D. Krasner (Ed.), International Regimes (pp.115-140). Ithaca, Greece: Cornell University Press.

Stein, A. R. (1993). Governments, Economic Interdependence, and International Cooperation. In P. Tetlock, J. L. Husbands, R, Jervis, P. C. Stern, \& C. Tilly (Eds.), Behaviour, Society and International Conflict. New York: Oxford University Press.

Su, C. H. (苏长和). (2000). Global Issues and International Cooperation - An Institutional Analysis (全球公共问题与国际合作: 一种制度的分析). Shanghai, China: Shanghai People's Publishing House.

Su, M. X. (苏美祥). (2011). From the Perspective of Endogenous Dynamics to Observe Cross-strait Economic Relationship after the Signing of ECFA (从内 生动力看 ECFA 时代两岸经贸关系的发展). Asia-pacific Economic Review (亚太经济), 4, 125-129.

Sun, L. J. (孙立极). (2010, July 30). Cross-strait Economic Relations Enter into the Era of Institutional Cooperation - An Explanation of ECFA (两岸经济关系步 入制度化合作—ECFA 解读). People's Daily (人民日报), p.10.

Sun, Z., \& Chen, X. (孙展, 陈晓). (2005). Influences of Taiwan Business People Behind the Mainland and Taiwan's Politics: Political Appeals and Economic Interactions (两岸政局背后的台商势力: 政治诉求经济互动). Retrieved from http://news.sina.com.cn/c/2005-05-23/11275963345s.shtml.

Sun, Z. H. (孙兆慧). (2008). An Observation about Aspects of the Role of Taiwan Business People (台商: 角色作用面面观). Research \& Exploration (研究与 探讨), 6, 38-40.

Taihainet. (2009). KMT Newspaper: Does the US Care if Taiwan Choose Reunification with the Mainland? Retrieved from http://www.taihainet.com/news/twnews/latq/2009-05-14/406770_2.shtml.

Taiwan Affairs Office of the State Council PRC. (国务院台湾事务办公室). (2006a). Statistics Regarding Cross-Strait Trade from 1978 to 2005 (1978-2005 年两 
岸贸易统计 ). Retrieved from http://www.gwytb.gov.cn/lajm/lajm/201101/t20110121_1718210.htm.

Taiwan Affairs Office of the State Council PRC. (国务院台湾事务办公室). (2006b). Cross-strait Trade Statistic and Analysis from 1979 to 2005 (1979-2005 年 两岸贸易依存度统计分析表)。 Retrieved from http://www.gwytb.gov.cn/lajm/lajm/201101/t20110121_1718211.htm.

Taiwan Affairs Office of the State Council PRC. (国务院台湾事务办公室). (2009). Statistics on Cross-strait Trade from 2000 to 2008 (两岸贸易统计 $2000-2008$ 年 ) $\quad$ Retrieved from http://www.gwytb.gov.cn/lajm/lajm/201101/t20110121_1718251.htm.

Taiwan Affairs Office of the State Council PRC. (国务院台湾事务办公室). (2009). Taiwan Business People’s Mainland Investment from 2000 to 2008 (台商投资 大陆统计表 2000-2008). Retrieved from http://www.gwytb.gov.cn/lajm/lajm/201101/t20110121_1718252.htm.

Taiwan Affairs Office of the State Council PRC. (国务院台湾事务办公室). (2009). Main Areas and Industries of Taiwan’s Mainland Investment (台湾对大陆投资 之主要地区 及应业). Retrieved from http://www.gwytb.gov.cn/tztw/twjmgk/201101/t20110118_1699300.htm.

Taiwan Affairs Office of the State Council PRC. (国务院台湾事务办公室). (2010). Statistics ont Cross-strait Trade and Investment from January to December 2009 (2009 年 1 - 12 月大陆与台湾贸易、投资情况). Retrieved from http://www.gwytb.gov.cn/lajm/lajm/201101/t20110128_1737094.htm.

Taiwan Affairs Office of the State Council PRC. (国务院台湾事务办公室). (2011). Statistics on Cross-strait Trade and Investment from January to December 2010 (2010 年 $1-12$ 月大陆与台湾贸易、投资情况). Retrieved from http://www.gwytb.gov.cn/lajm/lajm/201101/t20110128_1737103.htm.

Taiwan Affairs Office of the State Council PRC. (国务院台湾事务办公室). (2011). Statistics about Cross-strait Personal Exchange and Communication (历年两 岸人员往来于交流统计). Retrieved from http://www.gwytb.gov.cn/lajlwl/rywltj/201101/t20110120_1715616.htm. 
The Central People's Government of China News. (中央政府网站). (2005). The One China Principle ( 一 个中国原则). Retrieved from http://www.gov.cn/test/2005-07/29/content_18293.htm.

The Central People's Government of China News. (中央政府网站). (2011). Mr. Jia Qinglin and Mr. Wu Boxiong Attending the Opening Ceremony of the Seventh Cross-strait Economic, Trading and Cultural Forum (贾庆林吴伯雄出席第七 届两岸经贸文化论坛开幕式). Retrieved from http://www.gov.cn/ldhd/2011-05/07/content_1859400.htm.

The Economist. (2010). Asia: The Ties That Bind; China and Taiwan. The Economist, 396 (8689), 39.

Thucydides. (1972). History of the Peloponnesian War (R. Warner, Trans.). London, UK: Penguin Books Ltd.

Tian, Y. P. (田云鹏). (2010). The Contents and Significance of ECFA - An Interview with Mr. Wang Yi, the Director of the Taiwan Affairs Office of the Central Chinese Communist Party, the Director of the Taiwan Affairs Office of the State Council (ECFA 的内容与意义一一访中共中央台湾工作办公室、国务 院台湾事务办公室主任王毅). Theory Consultation (理论参考), 4, 27-28.

Tsai, T. I. (2010). World News: Asia: Ma promotes China pact. Retrieved from http://proquest.umi.com.helicon.vuw.ac.nz/pqdweb?did=2019819431\&sid=3\& Fmt $=3 \&$ clientId $=7511 \&$ RQT $=309 \&$ VName $=$ PQD.

Wachman, A. M. (2007). Why Taiwan? Geostrategic Rationales for China's Territorial Integrity. Stanford: Stanford University Press.

Waltz, K. N. (1979). Theory of International Politics. New York: Random House.

Waltz, K. N. (1993). The Emerging Structure of International Politics. International Security, 18(2), 44-79.

Wang, J. (2010a). Is the Honeymoon Over? Progress and Problems in Cross-strait Relations. American Foreign Policy Interests, 33(3), 147-168.

Wang, J. F. (王俊峰). (2011). ECFA and Cross-Strait Peaceful Development (ECFA 与两岸关系和平发展). Taiwan Research Quarterly (台湾研究集刊), 2, 18-25. 
Wang, J. J., Sun, G. N., \& Zheng, P. (王洁洁，孙根年，郑鹏). (2010). A Comparative Research about Hong Kong, Taiwan and Mainland China's Inbound Tourism Development (中国两岸三地入境旅游发展的比较研究). Resource Development \& Market (资源开发与市场), 26(4), 372-375.

Wang, J. M. (王建民). (1999a). Retrospect the Rough Road - Twenty Years Cross-strait Relations (回眸崎岖路——两岸经贸关系 20 年). Relations across the Taiwan Strait (两岸关系), 20, 5-7.

Wang, J. M. (王建民). (2009). Discussion about Establishing a Peaceful Cross-strait Development Frame (关于建立两岸关系和平发展架构问题的几点讨论). Asia \& Africa Review (亚非纵横), 1, 23-26.

Wang, J. M. (王建民). (2010b). ECFA Marks the Beginning of the Institutionalisation of Cross-Strait Economic Cooperation and Economic Integration (ECFA 开启 两岸经济合作制度化与经济一体化新局). Retrieved from http://theory.people.com.cn/GB/12128972.html.

Wang, L. Z. (王连忠). (2000). Retrospect and Prospect of Taiwan Business People's Mainland Investment since the Mainland's Reform and Opening Up (改革开放 以来台商投资大陆的回顾与前瞻 ). Retrieved from http://cpfd.cnki.com.cn/Article/CPFDTOTAL-JLSK200012001162.htm.

Wang, Y. W. (王义伟). (2010c, July 6). The Settlement of ECFA Marks a New Beginning in Cross-Strait Relations (ECFA 尘埃落定两岸关系揭开新篇). China Business Herald (中国商报), p.10.

Wang, Y. Z. (王逸舟). (1999b). International Politics - History and Theory (国际政 治学一历史与理论). Taipei, Taiwan: Wunan Press.

Wei, J. M. (卫敏丽). (2010). Ministry of Civil Affairs of China: Currently More than 300 Thousands Cross-strait Marriages Exist (民政部: 目前两岸婚姻已超过 30 万对). Retrieved from http://news.qq.com/a/20100427/002154.htm.

Wei, Y. (2004). From Functional Integration to Structural Readjustment: Taipei-Beijing Relations and the Role of the United States. Journal of Contemporary China, 13 (40), 427- 460. 
Wu, H. (1995). Bridging the Strait: Taiwan, China, and the Prospects for Reunification. Oxford: Oxford University Press.

Wu, N. Y. (吴能远). (2000). Taiwan Business People’s Mainland Investment and Cross-strait Relations - An Political and Economic Analysis (台商投资祖国大 陆与两岸关系——个政治经济之分析). Taiwan Research Quarterly (台湾 研究集刊), 1, 1-7.

Wong, K. T. W. (2010). The Emergence of Class Cleavage in Taiwan in the Twenty-First Century: The Impact of Cross-Strait Economic Integration. Issues \& Studies, 46 (2), 127-172.

Xie, B. C. (谢邦昌). (2010). Impacts of ECFA On Cross-strait Economy and Trade (ECFA 对两岸经贸的影响). Money China (财经界), 9, 21-25.

Xie, Y., Dang, C. S., Jin, Y., Zeng, R. M., Wu, Y., \& Yang, L. (谢郁，党朝胜，金奕， 曾润梅, 吴宜, 杨磊). (2006). A Research about Taiwan People's Opinion on “Reunification of China or Taiwan Independence” (台湾“统独”民意研究). Retrieved from http://www.cassits.cn/ztk/news_0028.html.

Xinhua News. (新华网). (2005). Hu Jintao and Lian Zhan Held Formal Talks in Beijing and Mentioned Four Points in the Development of Cross-strait Relations (胡锦涛和连战在北京举行正式会谈提发展两岸关系 4 点主张). Retrieved from http://news.xinhuanet.com/zhengfu/2005-04/30/content_2897412.htm.

Xinhua News. (新华网). (2011). The Mainland and Taiwan Benefits from ECFA and the Prospect for Further Cross-Strait Economic Integration (两岸初享ECFA 红利，经济整合能量将进一步释放). Retrieved from http://news.xinhuanet.com/local/2011-05/17/c_121427658.htm.

Xiong, J. L. (熊俊莉). (2005). Competition between the area of Taiwan and South Korea in the Mainland Market (台湾地区与韩国在大陆市场的博弯). Relations across the Taiwan Strait (两岸关系), 12, 24-25.

Yahuda, M. (1993). The Foreign Relations of Greater China. The China Quarterly, 136, 687-710. 
Yan, A. (闹安). (2006). A Policy Research about Taiwan Business People on the mainland from 1979-2005 (大陆台商政策研究: 1979-2005). Huhehaote, China: Inner Mongolia University Press.

Yan, A. (问安). (2011). Studies on Taiwan Business People's Investment on the Mainland from the Political and Economic Perspective - Also on Taiwan Compatriots and the Reform and Opening Up and Modernization Drive on the Mainland Over the Past Thirty Years (台商投资大陆经济政治研究——兼 及台湾同胞与祖国大陆改革开放和现代化建设三十年). History of the Chinese Communist Party Study (中共党史研究), 1, 53-69.

Yan, A. L. (严安林). (2009). New Meanings and Effects of the Mainland's Taiwan Policy (对台政策的新意与作用). Reunification Forum (统一论坛), 2, 24-25.

Yang, L. M. (杨丽明). (2011, November 2). APEC Summit Meeting in Hawaii Focussing on Three Issues - A Special Interview with Mrs. Monica, the Chairman of APEC (夏威夷 APEC 峰会聚焦三大议题——专访夏威夷 APEC 组委会主席莫妮卡). China Youth Daily (中国青年报), p.4.

Yu, K. L. (余克礼). (1999). Status and Roles of Taiwan Business People in the Development of Cross-strait Economy and Trade (台商在两岸经贸关系发展 中的地位与作用). Relations across the Taiwan Strait (两岸关系),4, 7-21.

Yu, K. L. (余克礼). (2009). Political Thinking about Cross-strait Development (关于 两岸政治关系发展的思考). China Report (中国报道), 10, 92-93.

Yu, K. L., Chen, K. L., Wang, X. B., Huang, J. S., \& Zhang, N. C. (余克礼 陈孔 立 王晓波 黄嘉树 章念驰). (2010). Cross-strait Political Trend after ECFA (ECFA 之后的两岸政治关系走向). Relations across the Taiwan Strait (两岸 关系), 8, 5-10.

Yuan, L., \& Li，S. F. (源流, 李少芬). (1997). Multi-consideration - The US' Construction of a New Asian Strategy (多维车动一美国构建新的亚洲战略). Journal of Lanzhou Commercial College (兰州商学院学报), 1, 36-39.

Zagoria, D. S., \& Fugarino, C. (Eds.). (2003). Breaking the China-Taiwan Impasse. Westport, Conn: Praeger. 
Zhang, C. G. (张传国). (2007a). Studies on Taiwan Business People's Mainland Investment (台商大陆投资问题研究). Beijing, China: The Commercial Press.

Zhang, C. G., \& Li, F. (张传国，李非). (2005). Taiwan Business People’s Investment to the Mainland Promotes Cross-strait Development (台商大陆投资对两岸关 系发展的推动效应). Taiwan Research Quarterly(台湾研究集刊), 2, 13-18.

Zhang, H. (张华). (2009). Analysis of Influence Factor on Peaceful Development of Cross-strait Relations under the New Situation (新形势下两岸关系和平发展 的影响因素分析). Journal of Jiangnan Social University (江南社会学院学 报), 11(1), 45-49.

Zhang, K. S. (张昆生). (2004). The Influences of Korean War to the Taiwan Issue (朝 鲜战争对台湾问题的影响). Observation and Thinking (观察与思考), 7, 44-46.

Zhang, L. (张莉). (2010). What Is ECFA Actually (ECFA 究竟是什么). Relations across the Taiwan Strait (两岸关系), 4, 22-23.

Zhang, X., \& Liu, C. L. (张幸, 刘传利). (2000). Striving to Expand Ways for the US to Increase its Fortune in Eastern Countries - A Review of Bill Clinton's Economic Strategy in the Asia-Pacific Region (努力拓展增长美国财富的东方 渠道——克林顿的亚太经济战略回顾). Academics in China (学术界), 2, 252-258.

Zhang, X. S. (张新声). (2007b). Watch the Real Face of “Taiwan Independence” from the “Four Demands and One Without” (从“四要一没有”看“台独”真面目). Reunification Forum (统一论坛), 2, 34-35.

Zhao, B. W. (赵蓓文). (2009). To Promote Economic Cooperation and Facilitate Mutual Development - An Summary of the Third "Cross-strait Economic and Trade Forum” (推进经济合作, 促进共同发展一一第三届 “两岸经贸论坛” 会议综述). International Economic Review (国际经济评论), 4, 64.

Zhao, Y. M. (赵郁美). (1996). Intense Cross-strait Political Relations Has No Impacts on Taiwan Business People's Investment to the Mainland (两岸关系紧张未影 响台商大陆投资). Reunification Forum (统一论坛), $1,7$. 
Zhao, Z. (赵志). (2002). The Reasons and Significances of China Joining APEC (中 国加入 APEC 的原因和意义). Journal of the Chengdu Municipal Party College of Chinese Communist Party (中共成都市委党校学报), 6, 37-38.

Zhong, M. Y., \& Xu, W. T. (钟岷源, 徐文婷). (2008). Study on Taiwanese Business People's Return to Taiwan for the Presidential election (台商返乡投票透视). South Wind Window (南风窗), 8, 25-27.

Zhou, J. (周军). (2008). Taiwan Business People on the mainland - An Interview with Sun Sheng Liang, Economic Director of Institute of Taiwan Studies, Chinese Academy of Social Sciences (台商在祖国大陆——访中国社会科学院台湾 研究所经济室主任孙升亮). Reunification Forum (统一论坛), 1, 41-44.

Zhou, J. M. (周建明). (2002). Taiwan Business People’s Mainland Investment and Its Impacts on Cross-strait Relations (台商对中国大陆的投资及对两岸关系的影 响). World Economy Study (世界经济研究), Additional Edition (增刊), 10-14.

Zhou, X. J. (周旭娇). (2010, December 17). Hundreds of President of Taiwan Business People’ Association Support ECFA (百名台协会长登报力挺 ECFA). Dongguan Daily (东莞日报), p. T13.

Zhu, B. N. (朱邦宁). (2008). Analyses of Cross-strait Economic and Trade Relations (海峡两岸经贸关系分析). Journal of Beijing Union University (Humanities and Social Sciences) (北京联合大学学报-人文社会科学版), 6 (4), 34-36.

Zhu, X. L. (朱显龙). (2004). Taiwan Business People in Cross-strait Interactions (两 岸互动中的台商). World Affairs (世界知识), 13, 40-41. 